\title{
39. NEOGENE DIATOMS FROM THE WESTERN MARGIN OF THE PACIFIC OCEAN, LEG 31, DEEP SEA DRILLING PROJECT
}

\author{
Itaru Koizumi, Institute of Geological Sciences, \\ College of General Education, Osaka University, Toyonaka, Osaka, Japan
}

\section{INTRODUCTION}

Leg 31 of the Deep Sea Drilling Project steamed west from Apra, Guam, on 15 June 1973 and drilled at nine sites in the West Philippine Sea including holes on the Palau-Kyushu Ridge, the Benham Rise, and the Shikoku Basin. During the final part of the cruise, four holes were drilled in the Sea of Japan, including a last site on the Yamato Rise before terminating in Hakodate on 4 August 1973 (Figure 1, Table 1). The primary purposes of this expedition were (1) to probe the history of the West Philippine Sea and the Sea of Japan, and (2) to obtain biostratigraphic reference sections beneath the track of the Kuroshio Current with its subtropical planktonic faunas and floras, as well as to study the lesser-known temperate and subarctic biofacies within the Sea of Japan.

A total of 320 samples from the 13 holes drilled on Leg 31 was examined for diatoms. Regretfully, no diatoms were observed in any of the core-catcher samples taken from the Western Philippine Sea (Sites 290 to 295) due to the lower primary production in the Kuroshio area, especially at lower latitudes (south of $30^{\circ} \mathrm{N}$ ). However, the abundance and preservation of diatoms in Pleistocene sections increases in the Shikoku Basin (Sites 296 to 298). Table 2 lists samples barren of diatoms at all sites. In contrast with the Philippine Sea, all of the sites in the Sea of Japan yielded abundant and well-preserved diatoms throughout the entire sequences and played a major role in biostratigraphic determination at each site (Sites 299 to 302). Study of these sequences allowed a significant advance in the field of diatom biostratigraphy.

Paleoclimatic fluctuations, based on the percentage of cold-water species, and paleosedimentological changes, based on the percentages of benthonic and fresh-water species, were analyzed during the Pliocene to Pleistocene interval at each site.

Correlation of Leg 31 sites was made with sections exposed along the adjacent continents using ranges of marine planktonic diatoms. In addition, correlations were made with sequences cored at various sites in the North Pacific, including the Sea of Japan, resulting in a useful diatom zonation for the northern circum-Pacific region.

Taxonomic references were made for all diatom taxa mentioned in this paper. Most of the marine planktonic diatoms are illustrated.

\section{PREPARATION OF SAMPLES AND METHOD OF STUDY}

All samples examined were taken by the writer onboard D/V Glomar Challenger from suitable levels in the core sections. The sample spacing in critical intervals was sufficiently close so that stratigraphic first and last appearances of selected species were determined with reasonable accuracy.

Original wet material of about $1 \mathrm{~g}$ (dry weight) was dropped into a 200-cc beaker of boiling hydrogen peroxide solution $\left(\mathrm{H}_{2} \mathrm{O}_{2}, 15 \%\right)$. Upon cooling, the beaker was filled with distilled water. After about $10 \mathrm{sec}$, when clastic grains and volcanic glass sank to the lower part of the bottom of the beaker, approximate quantities of the suspension containing diatom valves were taken by a 1$\mathrm{cc}$ pipette from the middle part of the water column in the beaker, and placed on a square cover glass $(18 \mathrm{~mm} \times$ $18 \mathrm{~mm}$ in size). The cover glass was dried on a hot plate at moderate temperature (about $60^{\circ}$ to $80^{\circ} \mathrm{C}$ ) and then mounted on a slide glass using Aroclor (solvent xylene, no. 4465 , nd 1.66). Preparation of hydrochloric acid $(\mathrm{HCl}, 25 \%)$ was not used.

Using a mechanical stage, lines in the center of the cover glass were transversed using a lens combination of $10 \times$ wide-field eyepieces and $70 \times$ oil immersion objective that occupies a field $250 \mu$ in diameter.

All diatom species noted while traversing lines in the field were identified and counted until a total of 100 or 200 specimens was accumulated (excluding the genus Chaetoceras). Only specimens representing more than one-half of a diatom valve were counted with the exception of genus Rhizosolenia. The frequencies of the fragments of Ethmodiscus rex and of Coscinodiscus wailesii (which are usually found only as fragments) were excluded from the regular counting and were recorded separately during the counting. The frequencies of each taxon thus obtained for each sample were not shown in the distribution charts (Tables 3 to 9).

Estimates of preservation are based on the degree of destroyed and dissolved condition of diatom valves.

Samples and slides studied in this report are stored in the Micropaleontologic Laboratory of the Institute of Geological Sciences, College of General Education at Osaka University, Toyonaka, Osaka, Japan.

\section{DIATOMS AT EACH SITE}

Tables 3, 4, 5, 6, 7, 8, and 9 list the abundance, preservation, and stratigraphic distribution of diatoms, zonal subdivision, and geologic age at Sites 296, 297, 298, 299, 300,301 , and 302 , respectively. All of the tables contain the following information about each sample studied for this report:

1) Columns on the left indicate the depth below sea floor $(\mathrm{m})$, core recovery $(\mathrm{m})$, core number, section number, and the interval of examined samplešcm). Each core, which at full recovery comprises 9 meters of sediment, is divided into six sections of $150-\mathrm{cm}$ sections 


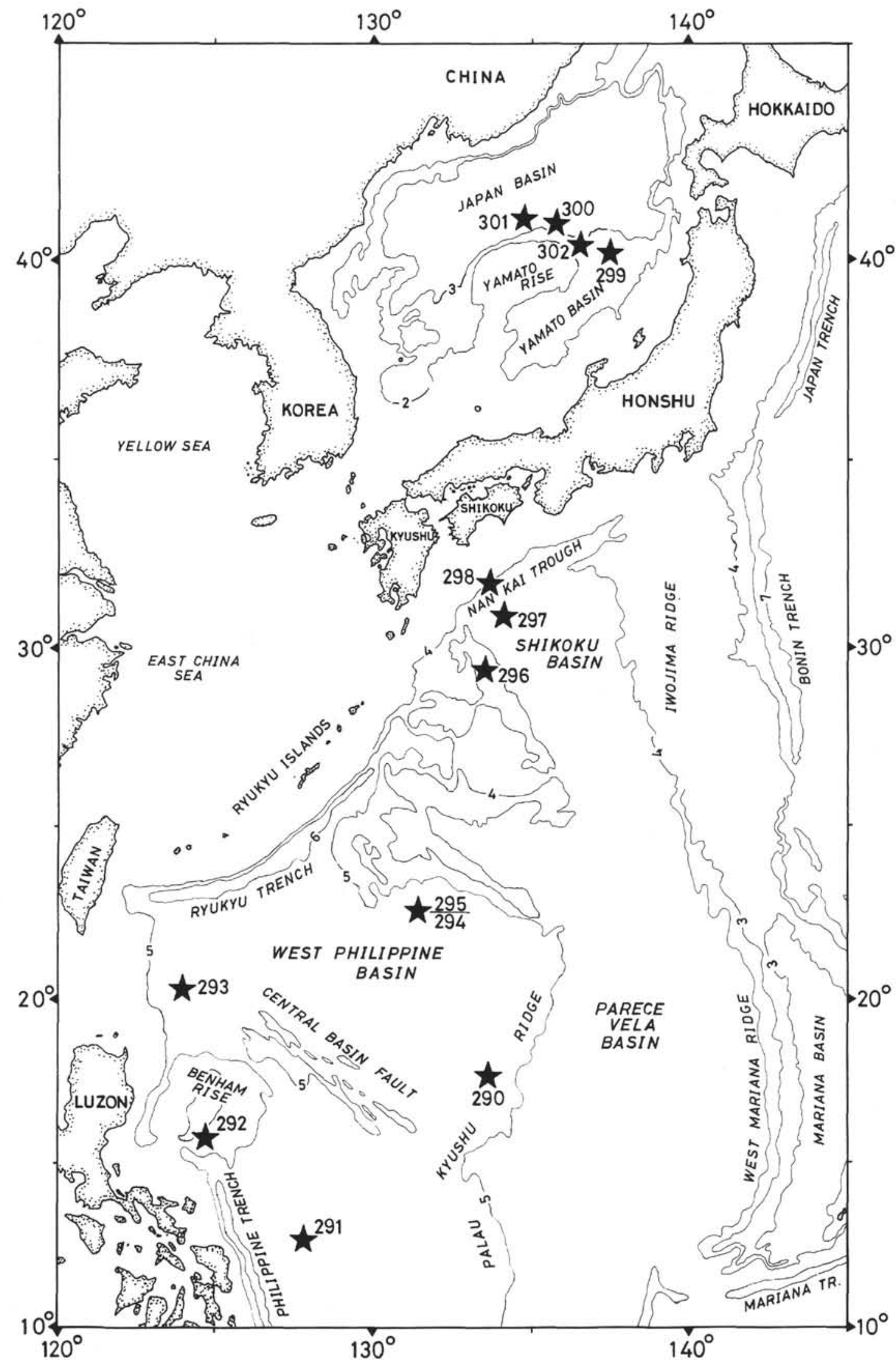

Figure 1. Location of drilling sites occupied on Leg 31, the West Philippine Sea and the Sea of Japan. Contour depths are in kilometers (from map "Topography of North Pacific" by T. E. Chase, H. W. Menard, and J. Mammerickx, Institute of Marine Resources, Geologic Data Center, Scripps Institution of Oceanography, 1971). 
TABLE 1

Leg 31 Site Data

\begin{tabular}{|c|c|c|c|}
\hline Site/Hole & Location & $\begin{array}{c}\text { Water } \\
\text { Depth (m) }\end{array}$ & $\begin{array}{l}\text { Penetration } \\
\text { (m) }\end{array}$ \\
\hline 290 & $\begin{array}{r}17^{\circ} 44.85^{\prime} \mathrm{N} \\
133^{\circ} 28.08^{\prime} \mathrm{E}\end{array}$ & 6062.5 & 255.0 \\
\hline $290 \mathrm{~A}$ & $\begin{array}{r}17^{\circ} 45.05^{\prime} \mathrm{N} \\
133^{\circ} 28.44^{\prime} \mathrm{E}\end{array}$ & 6062.5 & 140.0 \\
\hline 291 & $\begin{array}{r}12^{\circ} 48.43^{\prime} \mathrm{N} \\
127^{\circ} 49.85^{\prime} \mathrm{E}\end{array}$ & 5217.0 & 126.5 \\
\hline $291 \mathrm{~A}$ & $\begin{array}{r}12^{\circ} 43.45^{\prime} \mathrm{N} \\
127^{\circ} 48.99^{\prime} \mathrm{E}\end{array}$ & 5217.0 & 114.5 \\
\hline 292 & $\begin{array}{r}15^{\circ} 49.11^{\prime} \mathrm{N} \\
124^{\circ} 39.05^{\prime} \mathrm{E}\end{array}$ & 2943 & 443.5 \\
\hline 293 & $\begin{array}{r}20^{\circ} 21.25^{\prime} \mathrm{N} \\
124^{\circ} 05.65^{\prime} \mathrm{E}\end{array}$ & 5599 & 563.5 \\
\hline 294 & $\begin{array}{r}22^{\circ} 34.74^{\prime} \mathrm{N} \\
131^{\circ} 32.13^{\prime} \mathrm{E}\end{array}$ & 5784 & 118.0 \\
\hline 295 & $\begin{array}{r}22^{\circ} 33.76^{\prime} \mathrm{N} \\
131^{\circ} 22.04^{\prime} \mathrm{E}\end{array}$ & 5802 & 158.0 \\
\hline 296 & $\begin{array}{r}29^{\circ} 20.41^{\prime} \mathrm{N} \\
133^{\circ} 31.52^{\prime} \mathrm{E}\end{array}$ & 2920 & 1087.0 \\
\hline 297 & $\begin{array}{r}30^{\circ} 52.36^{\circ} \mathrm{N} \\
134^{\circ} 09.89^{\prime} \mathrm{E}\end{array}$ & 4458 & 679.5 \\
\hline $297 \mathrm{~A}$ & $\begin{array}{r}30^{\circ} 52.36^{\prime} \mathrm{N} \\
134^{\circ} 09.89^{\prime} \mathrm{E}\end{array}$ & 4458 & 200.5 \\
\hline 298 & $\begin{array}{r}31^{\circ} 42.93^{\prime} \mathrm{N} \\
133^{\circ} 36.22^{\prime} \mathrm{E}\end{array}$ & 4628 & 611.0 \\
\hline $289 \mathrm{~A}$ & $\begin{array}{r}31^{\circ} 42.93^{\prime} \mathrm{N} \\
133^{\circ} 36.22^{\prime} \mathrm{E}\end{array}$ & 4628 & 98.0 \\
\hline 299 & $\begin{array}{r}39^{\circ} 29.68^{\prime} \mathrm{N} \\
137^{\circ} 39.71^{\prime} \mathrm{E}\end{array}$ & 2599 & 532.0 \\
\hline 300 & $\begin{array}{r}41^{\circ} 02.96^{\prime} \mathrm{N} \\
136^{\circ} 06.30^{\prime} \mathrm{E}\end{array}$ & 3427 & 117.0 \\
\hline 301 & $\begin{array}{r}41^{\circ} 03.75^{\prime} \mathrm{N} \\
134^{\circ} 02.86^{\prime} \mathrm{E}\end{array}$ & 3520 & 497.0 \\
\hline 302 & $\begin{array}{r}40^{\circ} 20.13^{\prime} \mathrm{N} \\
136^{\circ} 54.01^{\prime} \mathrm{E}\end{array}$ & 2399 & 531.5 \\
\hline
\end{tabular}

numbered 1 through 6 from the top of the core. Samples taken within a given section are measured in centimeters from the top of the section. Core-catcher samples are designated by "CC" rather than an interval in centimeters.

2) Abundance is recorded as $B=$ barren, VR $=$ very rare (only very rare individuals on one slide), $\mathrm{R}=$ rare (a very few individuals per slide), $\mathrm{F}=$ few (several individuals per slide), $\mathrm{C}=$ common, and $\mathrm{A}=$ abundant.

3) Preservation is reported as $\mathrm{P}=$ poor, $\mathrm{M}=$ moderate, and $\mathrm{G}=$ good.

4) The marine planktonic diatoms are separated into extant and extinct diatoms based on the previous records of occurrences. The letters $\mathrm{C}$ and $\mathrm{W}$ indicate the cold- and warm-water species with italic letters used to denote extinct species.

5) Marine tychopelagic and benthonic diatoms are arranged alphabetically. A few brackish water species are listed within this column.

6) Fresh-water diatoms are also arranged alphabetically.

7) Six frequency grades for the occurrences of species are made as $\mathrm{A}=$ very abundant (more than 100 specimens), $A=$ abundant (60 to 99 specimens), $\mathrm{C}=$ common ( 40 to 59 specimens), $\mathrm{F}=$ few ( 20 to 39 specimens), $\mathrm{R}=$ rare (6 to 19 specimens), and $\mathrm{R}=$ very
TABLE 2

Core Catcher Samples Barren of Diatoms at Sites 290, 291, 292, 293, 294, and 295

\begin{tabular}{|c|c|}
\hline Site 290 & $\begin{array}{l}292-26, C C \\
292-27, C C\end{array}$ \\
\hline $290-1, \mathrm{CC}$ & $292-28, C C$ \\
\hline $290-2, \mathrm{CC}$ & $292-29, \mathrm{CC}$ \\
\hline $290-3, \mathrm{CC}$ & $292-30$, CC \\
\hline $290-4, \mathrm{CC}$ & $292-31, \mathrm{CC}$ \\
\hline $290-5, \mathrm{CC}$ & $292-32, \mathrm{CC}$ \\
\hline $290-6$, CC & $292-33$, CC \\
\hline $290-7$, CC & $292-34$, CC \\
\hline $290 \mathrm{~A}-1, \mathrm{CC}$ & $292-35$, CC \\
\hline $290 \mathrm{~A}-2, \mathrm{CC}$ & $\begin{array}{l}292-36, \text { CC } \\
292-37, \text { CC }\end{array}$ \\
\hline Site 291 & $\begin{array}{l}292-38, \text { CC } \\
292-39, \text { CC }\end{array}$ \\
\hline $291-1, \mathrm{CC}$ & \\
\hline $\begin{array}{l}291-2, \text { CC } \\
291-3, \text { CC }\end{array}$ & Site 293 \\
\hline $291-4, \mathrm{CC}$ & $293-1, \mathrm{CC}$ \\
\hline $291-5$, CC & $293-2$, CC \\
\hline $291 \mathrm{~A}-1, \mathrm{CC}$ & $293-3$, CC \\
\hline $291 \mathrm{~A}-2, \mathrm{CC}$ & $\begin{array}{l}293-4, C C \\
293-5, C C\end{array}$ \\
\hline Site 292 & $\begin{array}{l}293-6, \text { CC } \\
293-7, \text { CC }\end{array}$ \\
\hline $292-1$, CC & $293-8$, CC \\
\hline $292-2, \mathrm{CC}$ & $293-9$, CC \\
\hline $292-3$, CC & $293-10, \mathrm{CC}$ \\
\hline $292-4, \mathrm{CC}$ & $293-11$, CC \\
\hline $292-5$, CC & $293-12, \mathrm{CC}$ \\
\hline $292-6, \mathrm{CC}$ & $293-13$, CC \\
\hline $292-7$, CC & $293-14$, CC \\
\hline $292-8, \mathrm{CC}$ & $293-15, C C$ \\
\hline $292-9$, CC & $293-16, \mathrm{CC}$ \\
\hline $292-10$, CC & $293-17, \mathrm{CC}$ \\
\hline $292-11, \mathrm{CC}$ & \\
\hline $292-12$, CC & Site 294 \\
\hline $292-13$, CC & \\
\hline $292-14$, CC & $294-1, \mathrm{CC}$ \\
\hline $292-15, \mathrm{CC}$ & $294-2$, CC \\
\hline $292-16$, CC & $294-3$, CC \\
\hline $292-17$, CC & $294-4$, CC \\
\hline $292-18$, CC & $294-5$, CC \\
\hline $292-19$, CC & $294-6, \mathrm{CC}$ \\
\hline $292-20$, CC & \\
\hline $292-21, \mathrm{CC}$ & Site 295 \\
\hline $292-22, \mathrm{CC}$ & \\
\hline $292-23, \mathrm{CC}$ & $295-1, \mathrm{CC}$ \\
\hline $292-24, \mathrm{CC}$ & $295-2, \mathrm{CC}$ \\
\hline $292-25, \mathrm{CC}$ & $295-3, C C$ \\
\hline
\end{tabular}

rare ( 1 to 5 specimens). Reworked specimens are distinguished by italic letters in the tables.

8) Zones and age are indicated on the right of each table. Age and diatom zonations used in this report follow those proposed by Burckle (1972) for Sites 296 to 298 near Shikoku Island, and Koizumi (1973b) for Sites 299 to 302 in the Sea of Japan with modifications.

\section{Philippine Sea (Sites 290 to 295)}

Diatom valves were not observed in all of the corecatcher samples from this area onboard Glomar Challenger (Sites 290 to 295); consequently, no further observations were made (Table 2). 


\section{Shikoku Island Area (Sites 296 to 298)}

\section{Site 296 (Table 3)}

Site 296 was drilled on a sediment-covered terrace on the western side of the Palau-Kyushu Ridge at a water depth of 2920 meters (Figure 1, Table 1). The hole was continuously cored to a subbottom depth of 472 meters (296-50, CC). Thereafter, coring at irregular intervals was carried out to a depth of 1087 meters $(296-65$, CC) where tuffs and lapilli tuffs were recovered. The stratigraphic sequence consists of 634 meters of early to late Oligocene volcanic clastics overlain by 453 meters of late Oligocene through Pleistocene ash-bearing nannofossil oozes and chalks.

TABLE 3

Abundance and Stratigraphic Distribution of Diatoms, Site 296

\begin{tabular}{|c|c|c|c|c|c|c|c|c|c|c|c|}
\hline $\begin{array}{l}\text { LEG } 3 \\
\text { SITE } 29 \\
\text { CORES }\end{array}$ & & & & $\begin{array}{l}\text { MARII } \\
\text { AND }\end{array}$ & $\begin{array}{l}\mathrm{NE} \\
\mathrm{BE}\end{array}$ & & $\begin{array}{l}\text { ANKTONIC DIATOMS } \\
\text { HONIC DIATOMS }\end{array}$ & $\begin{array}{l}\text { S-TYCP } \\
-Z\end{array}$ & $\begin{array}{ll}\mathrm{CHOP} \\
\mathrm{ZON}\end{array}$ & & \\
\hline SAMPL & & & & $\begin{array}{r}\text { IES AN } \\
\text { ECO }\end{array}$ & & & $\begin{array}{l}\text { marine planktonic } \\
\text { diatoms }\end{array}$ & 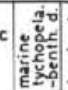 & 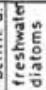 & & \\
\hline 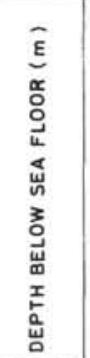 & 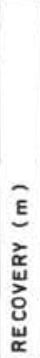 & 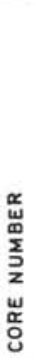 & 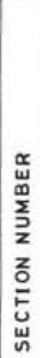 & 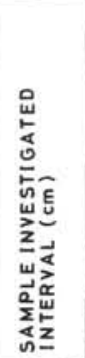 & 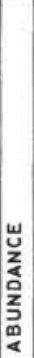 & 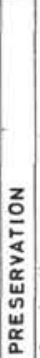 & $\begin{array}{l}\text { EXTANT DIATOMS } \\
\text { WW WWW w } \\
\text { W }\end{array}$ & 等 & 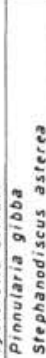 & 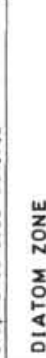 & $\begin{array}{l}\text { ü } \\
0\end{array}$ \\
\hline $0=6.5$ & 5.9 & 1 & cc & $45-46$ & $\begin{array}{ll}V R \\
R\end{array}$ & \begin{tabular}{|l}
$p$ \\
$p$ \\
$m$
\end{tabular} & 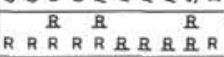 & ${ }^{R}{ }^{B}$ & B & & 总 \\
\hline $6.5-16$ & 7.7 & 2 & $\begin{array}{ll}2 \\
c c\end{array}$ & $75-76$ & $\begin{array}{l}\text { VR } \\
\text { VR }\end{array}$ & $\begin{array}{l}p \\
p \\
p\end{array}$ & $\mathrm{R}^{\mathrm{B}} \mathrm{R}^{\mathrm{R}}$ & R & & & \\
\hline $\begin{array}{l}16-25.5 \\
255-35\end{array}$ & $\begin{array}{l}5.9 \\
5.0\end{array}$ & $\frac{3}{4}$ & $\begin{array}{l}\mathrm{CC} \\
\mathrm{CC}\end{array}$ & & $\frac{1}{B R}$ & $\frac{p}{p}$ & & & B & & 붐 \\
\hline
\end{tabular}

Diatoms are absent in most samples collected from Site 296 except for some samples in the uppermost section. Five samples from Cores 1 to 3 ( 0 to $25.5 \mathrm{~m}$ ) contain the first diatoms recovered on Leg 31 , but these cases represent the only intervals at Site 296 in which diatoms were observed. The abundance and state of preservation of diatom valves, which occur frequently in the moderate to well preserved in Core 1 ( 0 to $6.5 \mathrm{~m})$, rapidly decrease with age.

Diatom-bearing samples at Site 296 belong to the Pseudoeunotia doliolus Zone (Recent to Pleistocene) of Burckle (1972). Some marine tychopelagic and freshwater species are also present.

\section{Site 297 (Table 4)}

Site 297 was drilled at the westernmost corner of the Shikoku Basin immediately south of the Nankai Trough and Shikoku Island at a water depth of 4458 meters (Figure 1, Table 1). Hole 297 reached 697.5 meters below the sea floor (297-27, CC). The stratigraphic section consists of 54 meters (297-1, CC to 297-4, CC) of Pleistocene diatom/ash-rich clay; 36 meters (297-5-1, 0 $\mathrm{cm}$ to $297-6-5,150 \mathrm{~cm}$ ) of Pleistocene clay-rich nannofossil ooze; 240 meters (297-6, CC to 297-14, CC) of Pleistocene-late Pliocene claystone; 240 meters (297-15$1,0 \mathrm{~cm}$ to $297-22, \mathrm{CC}$ ) of late early Pliocene claystone with interbedded graded silt and sand; and 127.5 meters (297-23-1, $110 \mathrm{~cm}$ to $297-27$, CC) of early Pliocene to middle Miocene vitric ash and ash-rich claystone.

Diatoms are few to common in number and moderately well preserved from Cores 1 to 6 (0 to 86.5 $\mathrm{m})$. A few fragments of poorly preserved diatom valves are occasionally observed in samples from Cores 7 through 27 (96 to $679.5 \mathrm{~m}$ ).

Most marine planktonic diatoms in the upper 86.5 meters are restricted to the characteristic warm-water diatom thanatocoenoses, which all belong to the Pseudoeunotia doliolus Zone of Burckle (1972). Few to

TABLE 4

Abundance and Stratigraphic Distribution of Diatoms, Site 297

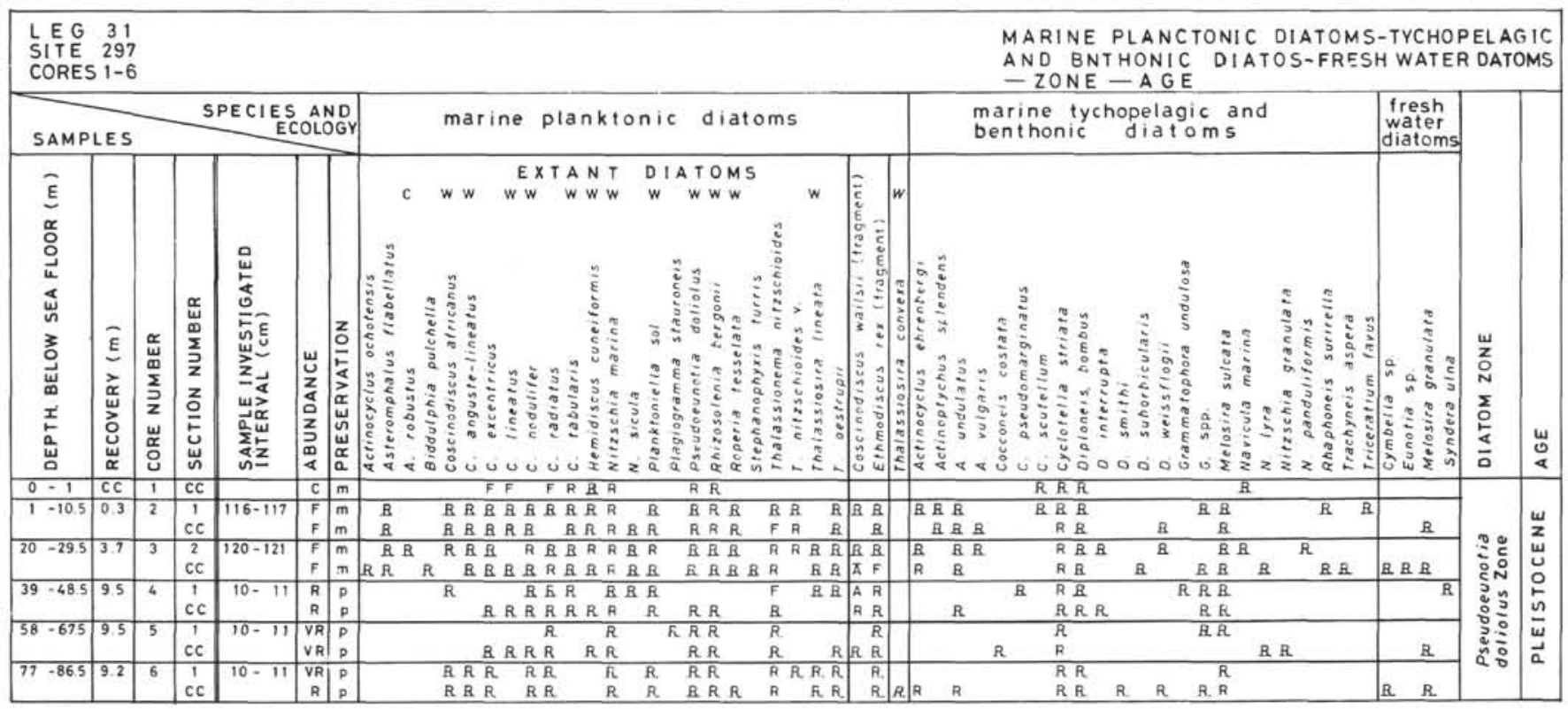


many fragments of extremely large Coscinodiscus wailesii and Ethmodiscus rex occur throughout Pleistocene portions of the hole. Kanaya and Koizumi (1966) remarked on the occurrence of Coscinodiscus wailesii in plankton and in deep-sea sediments of the North Pacific and described this species as one not interpretable as either cold- or warm-water species. Moreover, this species is now living in the eastern part of the North Pacific, but is found only in the lower parts of the cores from the western part of the North Pacific. An interpretation of Ethmodiscus ooze which consists mainly of Ethmodiscus rex was recently made by Schrader (1974). Many fragments of the frustules of Kieselavia carina, an index species of middle to late Miocene age, were encountered in the core-catcher sample from Core 25 ( 647 to $656.5 \mathrm{~m})$, but no fragments were found on the slides from the same sample during shore-laboratory studies.

Many marine tychopelagic and a few fresh-water species occur throughout the uppermost portion (0 to $86.5 \mathrm{~m}$ ) of Hole 297. Reworked and/or displaced shallow-water species, Cocconeis scutellum (marine benthonic species) and Melosira granulata (fresh-water species) were found in the core-catcher sample of Core 9 (124.5 to $134 \mathrm{~m})$.

\section{Site 298 (Table 5)}

Site 298 was drilled on the relatively steep west wall of the Nankai Trough off Shikoku Island at a water depth of 4622 meters (Figure 1, Table 1), and Hole 298 penetrated 611 meters below the sea floor (298-16, CC). The stratigraphic section consists of 183.75 meters (298$1-1,120 \mathrm{~cm}$ to $298-4-1,25 \mathrm{~cm}$ ) of Holocene to late Pleistocene turbidite sands, silts, and clays underlain by 427.25 meters $(298-4-1,25 \mathrm{~cm}$ to $298-16$, CC) of early Pleistocene fissile clay (stone), silt (stone), and clayey and silty sands.

Diatoms are rare to a few and moderately to badly preserved throughout the samples of Site 298 except in the following samples: 298A-1-1, $137-138 \mathrm{~cm} ; 298-5-2$, $102-103 \mathrm{~cm} ; 298-6-1,80-81 \mathrm{~cm} ; 298-10-1,43-44 \mathrm{~cm}$; 29811-3, 23-24 cm; 298-11, CC; 298-13-1, 36-37 cm; 298-15, CC; and 298-16, CC; where they are very few or completely absent.

Only the Quaternary diatom zone (Pseudoeunotia doliolus Zone of Burckle 1972) for the tropical area was defined. Fragments of Coscinodiscus wailesii were predominantly found in some samples in the interval from 425 meters $(298-12-3,100-101 \mathrm{~cm})$ to 525.5 meters (298-14, CC).

Marine tychopelagic and benthonic species and freshwater species are commonly scattered throughout all sections.

\section{Sea of Japan: Sites 299 to 302}

\section{Site 299 (Table 6, Figure 2)}

Site 299 was drilled into a submarine canyon fan complex in the Toyama Trough within the northeastern Yamato Basin at a water depth of 2599 meters (Figure 1, Table 1). The seismic records indicate that this portion of the basin in underlain by at least 500 meters of turbidite deposits and an equal thickness of pelagic sediment. The upper seismic sequence is similar to the deformed Neogene sedimentary column exposed in northwestern Honshu where Pleistocene through Pliocene turbidites overlie late to middle Miocene diatomaceous mudstone. Coring was undertaken continuously from Core 1 ( 0 to $9.5 \mathrm{~m}$ ) through Core 27 (256.5 to $266 \mathrm{~m}$ ), followed by irregular intervals through Core 37 (513 to $522.5 \mathrm{~m}$ ) with continuous coring near the base of the hole (Core 38, 522.5 to $532 \mathrm{~m}$ ) due to the presence of gases. The major lithology of the sediments is clayey silt and silty clay, and distinct lithological changes are lacking. However, various stages of submarine fan development were distinguished and classified as a lateral and vertical migrating complex of fan channel, levee, and overbank deposits by Bouma (this volume).

Diatoms are generally moderate, sometimes very rare in abundance, and moderate to poorly preserved through almost the sequence from Core $1(0$ to $9.5 \mathrm{~m})$ to Core 31 ( 351.5 to $361 \mathrm{~m}$ ). Diatoms in Cores 32 through 38 (399 to $532 \mathrm{~m})$ are very rare to absent. Fluctuations in the smoothed curved of estimated diatom number correlate with the depositional curve for the sediments of Hole 299 as given by Bouma (this volume). Namely, there is the tendency for the number of diatom individuals to be high in the (inner) levee deposits and low in the (outer) levee, channel, and overbank deposits.

Six diatom zones were recognized without breaks except for the lower two zones. The base of the Denticula seminae Zone is at 93 meters (299-2, CC); the base of the Rhizosolenia curvirostris Zone is at 19 meters (299-10-5, 104-105 cm); the Actinocyclus oculatus Zone at 159 meters (299-17-4, 75-76 cm); and the Denticula seminae v. fossilis Zone is at 304 meters $(299-29$, CC). The base of the Denticula seminae v. fossilis-Denticula kamtschatica. Zone is within the interval from 332.5 meters (299-30, CC) to 496 meters (299-36-1, 83-84 cm), whereas the base of the Denticula kamtschatica Zone has not been defined. Cold-water species are generally present in greater numbers than the warm-water species; this trend is remarkable within the late Pleistocene (Denticula seminae and Rhizosolenia curvirostris zones) and parts of the Pliocene (upper part of Denticula seminae v. fossilis Zone and Denticula seminae v. fossilis-Denticula kamtschatica Zone).

Many kinds of marine tychopelagic-benthonic and fresh-water species occur throughout the section. There are three major maxima in the percentage curve of marine benthonic species. The highest maximum occurs in the neighborhood of the Pliocene-Pleistocene boundary (uppermost of the Denticula seminae v. fossilis Zone and the Actinocyclus oculatus Zone). The second and third maxima are in the lower part of the Denticula seminae v. fossilis Zone and the Denticula seminae v. fossilis-Denticula kamtschatica Zone, respectively. The occurrences of fresh-water species are slightly high through the late Pleistocene section (Denticula seminae and Rhizosolenia curvirostris zones).

Older reworked Miocene species are common in the late Pleistocene section, but are sporadic in the lower section. 
TABLE 5

Abundance and Stratigraphic Distribution of Diatoms, Site 298

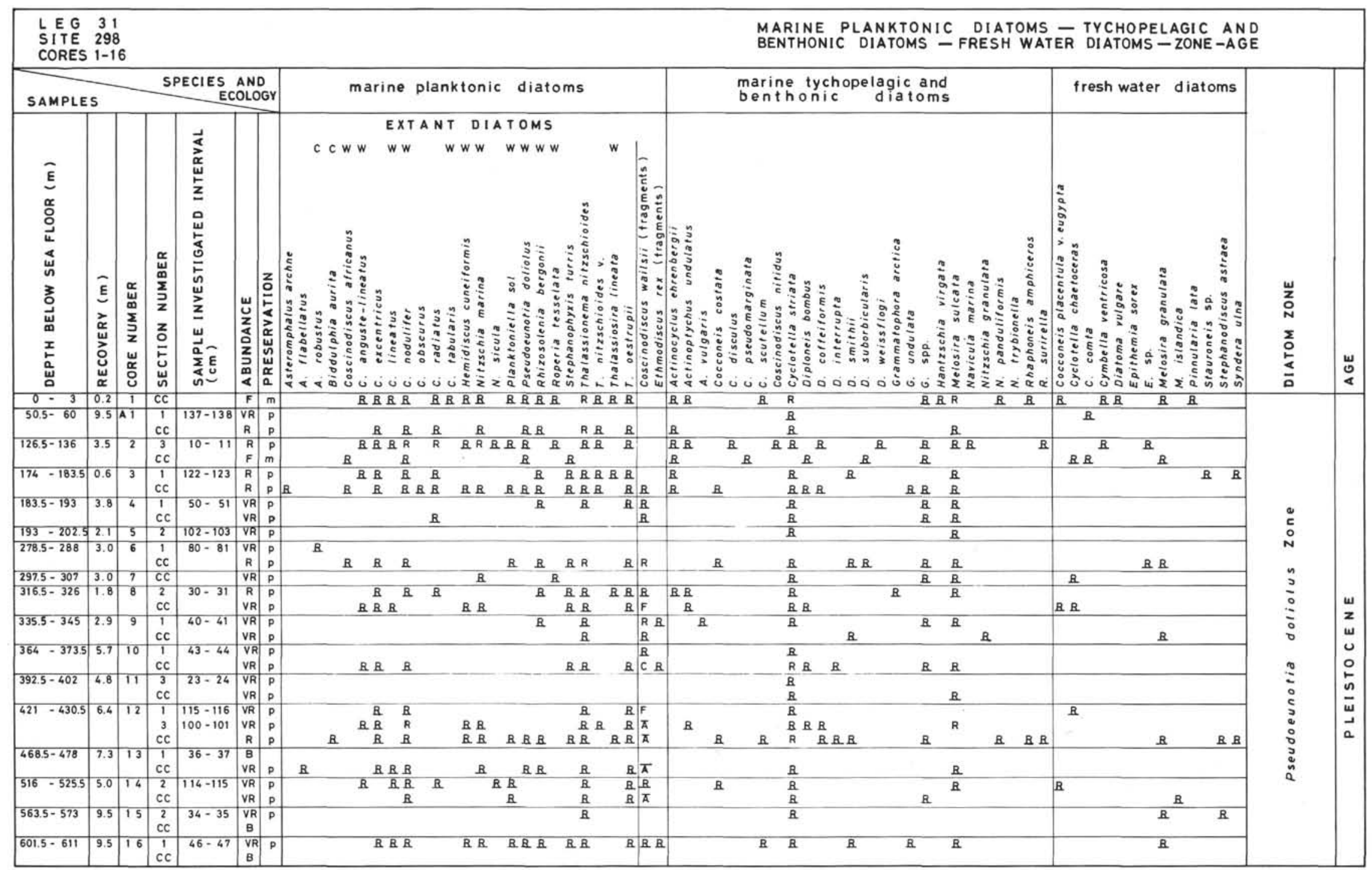




\section{Site 300 (Table 7)}

Site 300 was drilled on the eastern Japan Abyssal Plain (or Basin) adjacent Yamato Rise at a water depth of 3427 meters. This hole was terminated at 117 meters after only two cores were pulled because of thick, unconsolidated sandy turbidites. These sediments consist of diatom silty clay, sand, and silty clay.

Diatoms are rare to very rare in abundance and poorly preserved. Only the youngest two diatom zones were defined at Site 300 , samples from Core 1 ( 0 to $1 \mathrm{~m})$ representing the Denticula seminae Zone, and Core 2 (105.5 to $117 \mathrm{~m})$ the Rhizosolenia curvirostris Zone.

Displacement of marine littoral species occurs throughout all the samples and older reworked species are common within the late Pleistocene section.

\section{Site 301 (Table 8, Figure 3)}

Site 301 was drilled on the east central position in the abyssal plain of the Japan Basin at a water depth of 3520 meters (Figure 1, Table 1). Twenty cores were taken over a 497-meter interval before the hole was abandoned due to the increasing presence of ethane gas. The sedimentary section consists of 240.5 meters (301-1, CC to $301-7, \mathrm{CC}$ ) of distal turbidites (fine sands, silts, and clays) underlain by 256 meters (301-8-1, $0 \mathrm{~cm}$ to $301-20$, $\mathrm{CC}$ ) of clayey diatomite and diatomaceous claystone with a sandy clayey siltstone or clayey silty sandstone within the interval from Core 17 through Core $20(449.5$ to $497 \mathrm{~m}$ ).

Diatoms are abundant to common in abundance and well preserved in most samples collected from Site 301 except for those samples within the following intervals. They are rare to very rare and poorly preserved within the interval from 173.5 meters to 221.5 meters (301-5-1, $80 \mathrm{~cm}$ to $301-7, \mathrm{CC}$ ) and from 487 meters to 491.5 meters (301-19, CC to 301-20-2, 123-124 cm). The first interval is near the Pliocene-Pleistocene boundary. According to the lithologic analysis of the sediment section recovered, turbidite sands and silts are most abundant throughout those parts (301-1, CC to 301-7, CC, and $301-15-1,0 \mathrm{~cm}$ to $301-20$, CC).

Five diatom zones were recognized, and a good subarctic late Pleistocene throughout early Pliocene diatom biostratigraphic section was observed. The uppermost Denticula seminae Zone was not found due to a lack of samples representing this zone. The base of the Rhizosolenia curvirostris Zone is at 126.5 meters $(301-2$, CC). The base of the Actinocyclus occulatus Zone was not decided clearly by rare valves, and so it was tentatively placed at 202.5 meters (301-6, CC). The base of the Denticula seminae v. fossilis Zone is at 345 meters (301-12, $\mathrm{CC})$, of the Denticula seminae v. fossilis-Denticula kamtschatica Zone at 423 meters (301-16-1, 71-72 cm); whereas the base of the Denticula kamtschatica Zone was not detected. The numbers of warm-water species are essentially negligible in comparison with the abundance of cold-water species. The latter increases gradually from the boundary of Pliocene-Pleistocene (lower part of the Actinocyclus oculatus Zone) to late Pleistocene (uppermost part of the Actinocyclus oculatus Zone to lower part of the Rhizosolenia curvirostris Zone).
Many kinds of marine tychopelagic-benthonic species occur throughout the section. The percentage of marine benthonic species is especially high in the neighborhood of the Pliocene-Pleistocene boundary and lower Pleistocene section.

Displaced fresh-water and older reworked extinct species are frequently found in the late Pleistocene section, and they are sporadically encountered throughout other parts of the cored interval.

\section{Site 302 (Table 9, Figure 4)}

Site 302 was drilled on the northern flank of the Yamato Rise in the central Sea of Japan at a water depth of 2399 meters (Figure 1, Table 2). The first 15 cores ( 0 to $275.5 \mathrm{~m})$ represent an alternately washing and coring program; Cores 16 ( 351.5 to $361 \mathrm{~m}), 17$ (456 to $465.5 \mathrm{~m})$, and $18(528.5$ to $531.5 \mathrm{~m})$ were cored at intervals of 85.5 meters, 104.5 meters, and 72.5 meters, respectively. The stratigraphic section recovered consists of 28.5 meters (302-1, CC to 302-2, CC) of diatom ooze and ash; 28.5 meters $(302-3-1,0 \mathrm{~cm}$ to $302-4, \mathrm{CC})$ of zeolitic clay and micarb; 199 meters $(302-5-1,70 \mathrm{~cm}$ to $302-15, \mathrm{CC})$ of diatomaceous ooze; 254.5 meters (302$16-1,70 \mathrm{~cm}$ to $302-17, \mathrm{CC}$ ) of zeolitic clay; and 2 meters (302-18, CC) of unfossiliferous silty volcanic sand and green tuff. The upper 361 meters (302-1, CC to 302-16, CC) of this column contains a good siliceous biostratigraphic reference section representing a dominantly boreal biofacies.

Diatoms are common to abundant and well preserved in most cores from the sea floor to a depth of 354 meters (302-1, CC to 302-16-1, 98-99 cm) except for Cores 3 and $4(38$ to $66.5 \mathrm{~m})$ where they are very rare and poorly preserved. Below 360.5 meters (302-16, CC) diatoms are very sparse or completely absent.

Five diatom zones to the Denticula kamtschatica Zone were recognized without the uppermost Denticula seminae Zone similar to Site 301 . The base of the Rhizosolenia curvirostris Zone is at about 25.5 meters (302-2-4, $60-61 \mathrm{~cm}$ ), and the precise position of the base of the $\mathrm{Ac}$ tinocyclus oculatus Zone is difficult to determine due to sparse diatoms in the critical interval similar to Site 301 . This boundary was tentatively placed at 47.5 meters (302-3, CC). The base of the Denticula seminae v. fossilis Zone is at 81 meters $(302-5-3,50-51 \mathrm{~cm})$, the base of the Denticula seminae v. fossilis-Denticula kamtschatica Zone is at 136 meters $(302-8-2,10-11 \mathrm{~cm})$, and the base of the Denticula kamtschatica Zone has not been defined. Cold-water species are dominant in the marine planktonic assemblage and the percentage of these species gradually increases from the Pliocene (Denticula kamtschatica Zone) to the middle Pleistocene (lower part of the Rhizosolenia curvirostris Zone) sections. The percentage is high throughout the Pliocene section, too.

Marine tychopelagic-benthonic species occur frequently throughout all positions of the section. Several displaced fresh-water species are exclusively found in the Pleistocene section.

Reworked extinct species are observed above the Pliocene-Pleistocene boundary. 
TABLE 6

Abundance and Stratigraphic Distribution of Diatoms, Site 299

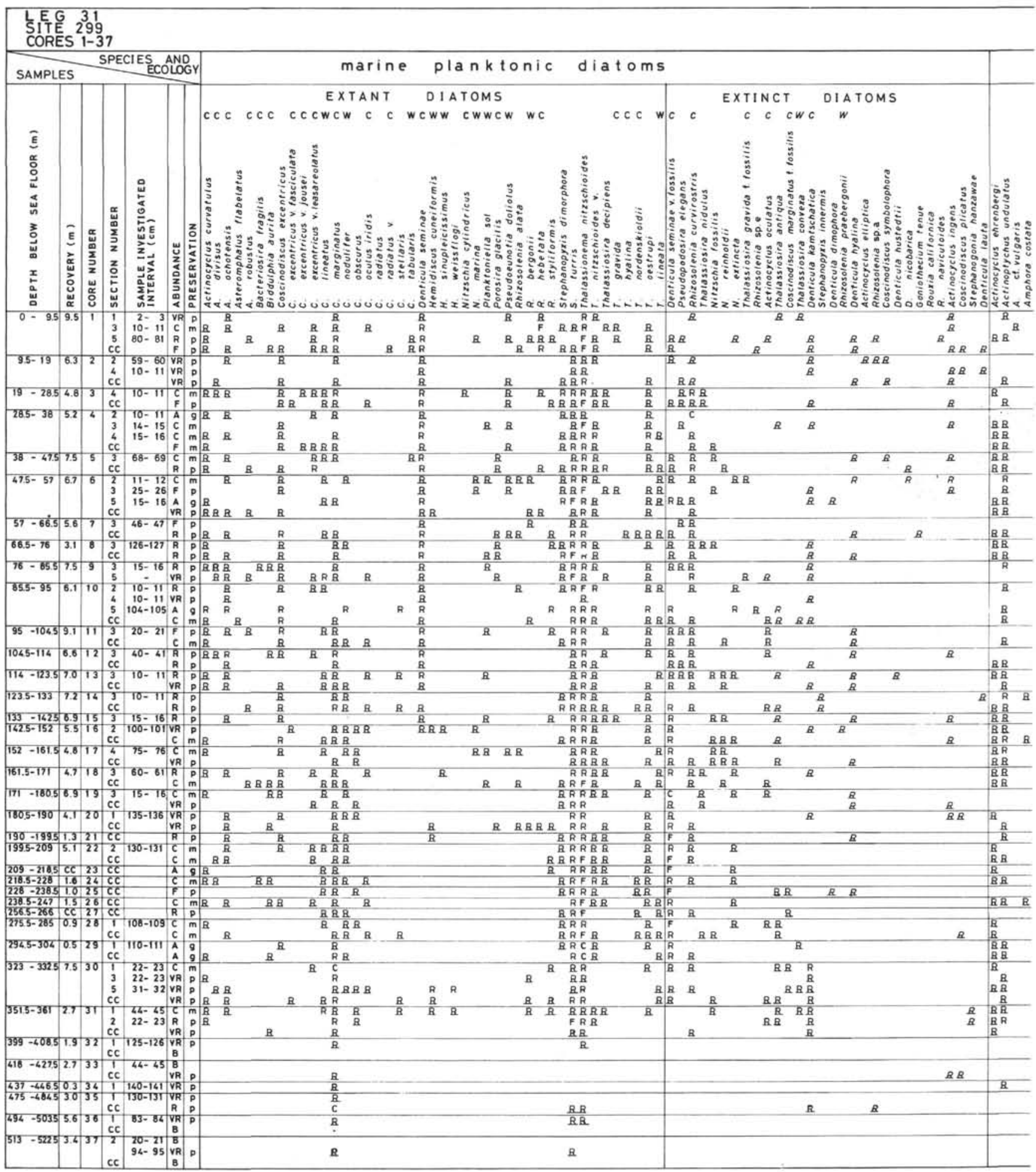


TABLE 6 - Continued

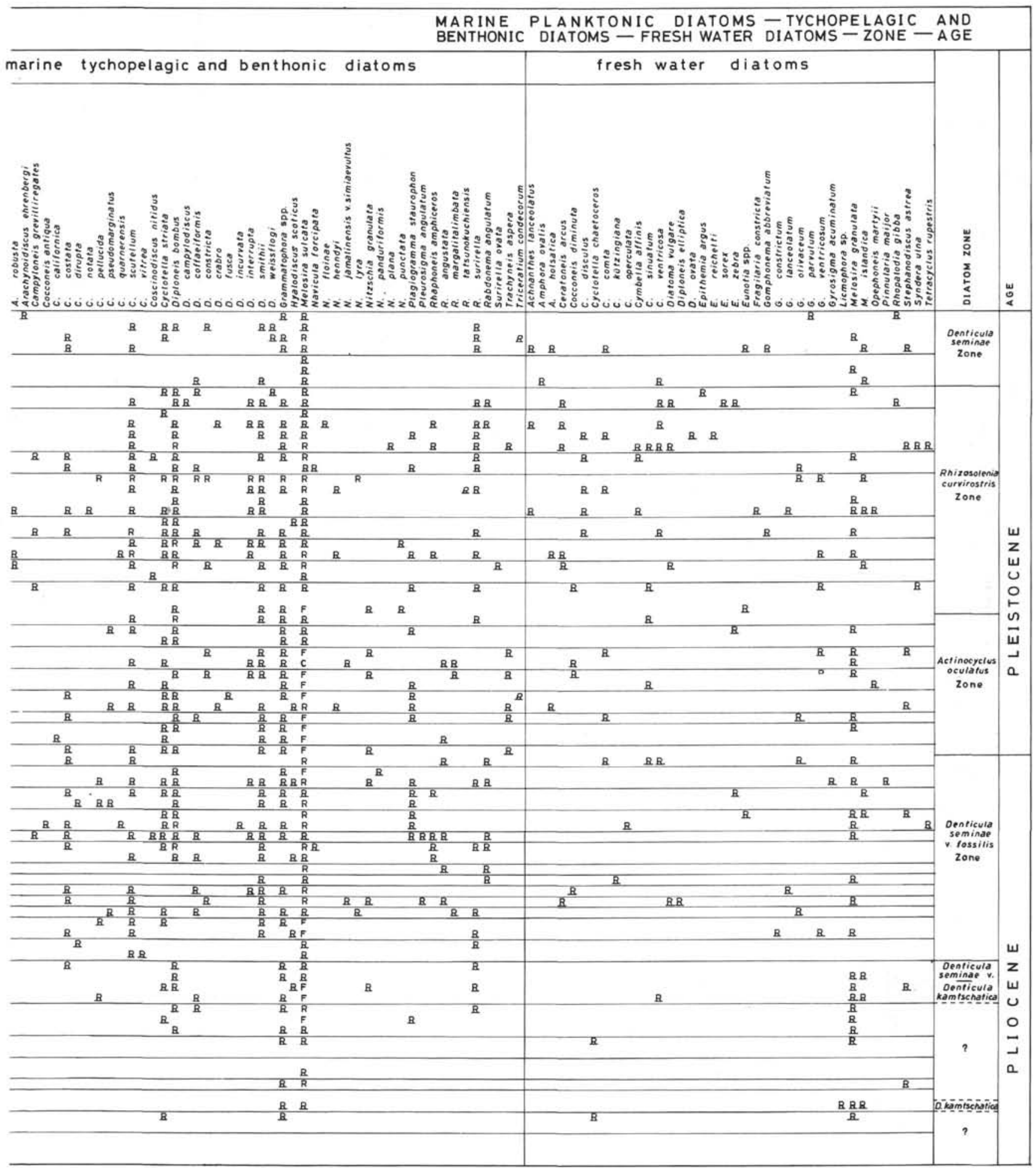




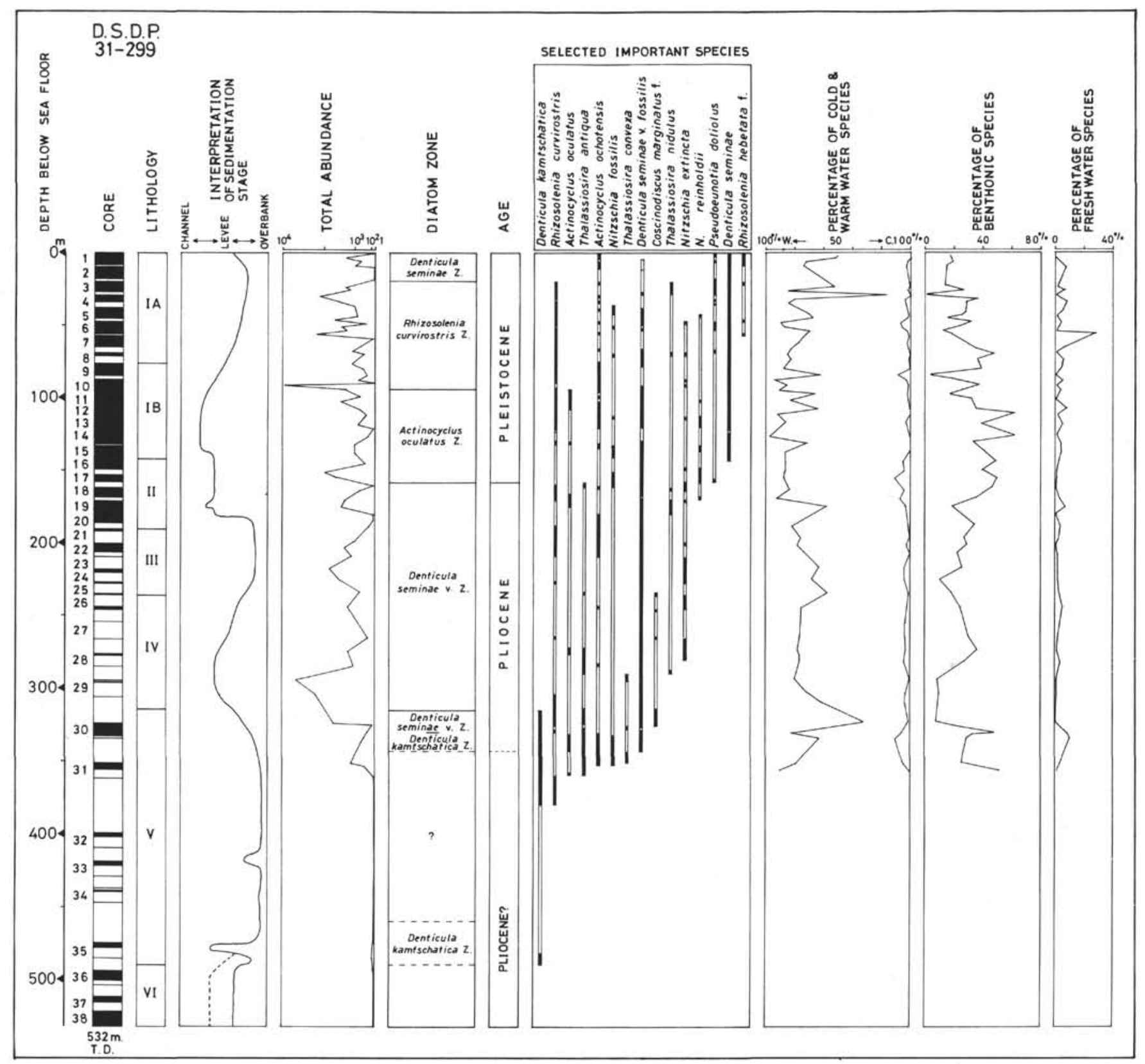

Figure 2. Stratigraphic variation of selected groups of species and ranges of selected planktonic species, Site 299. Black area in the core column represents cored sequences and that in the ranges of selected species show where those species occurred. Abbreviation: IA, alternating beds of clayey silt and silty clay; IB, similar to IA but amount of sand beds increases downward; II, alternating beds of sandy silt, silty sand, clayey silt, and silty clay; III, clayey silt and silty clay; IV, clayey silts, silty clays, silty sands, and sandy silts; $V$, silty clay and clayey silt with a few: volcanic ash and carbonate interbeddings; VI, alternating beds of thin and medium-bedded clays-slightly silty clays, and volcanic ash (after Bouma, this volume).

TIME RANGES OF SELECTED TAXA AND BIOSTRATIGRAPHIC ZONATION

According to the classification of diatom assemblages by Kanaya and Koizumi (1966) the marine planktonic species compositions shown in Tables 3 to 9 indicate that a subtropical assemblage of planktonic diatoms comparable in character to the "Central Assemblage" of the modern North Pacific sediment prevailed at Sites
296 to 298 from off Shikoku Island area and an arctoboreal assemblage comparable to the "Northwest Marginal Assemblage" dominated at Sites 299 to 302 from the Sea of Japan. Two biostratigraphic zonal schemes were used, therefore, in this study. One is the zonation of Burckle (1972) for Sites 296 to 298, and the other is the incorporated zonation of Koizumi (1973a, 1973b) for Sites 299 to 302. 
TABLE 7

Abundance and Stratigraphic Distribution of Diatoms, Site 300

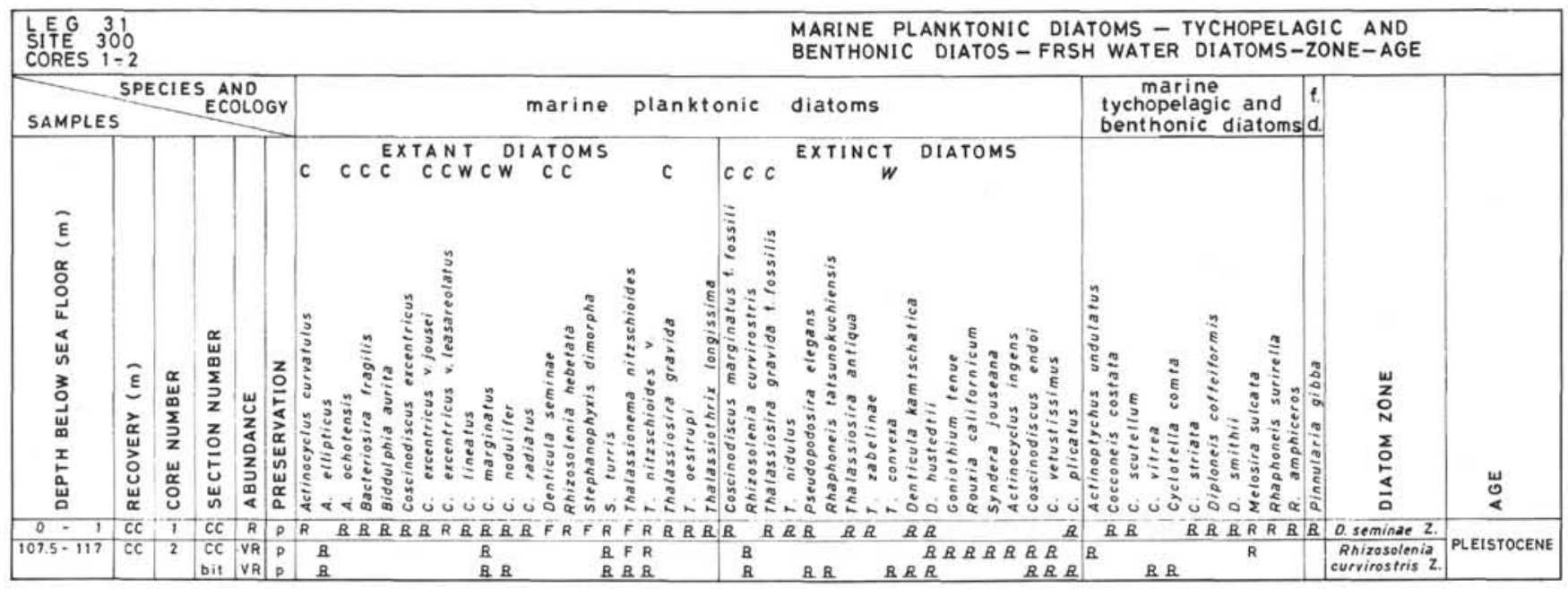

\section{Off Shikoku Area: Sites 296 to 298}

\section{Pseudoeunotia doliolus Range Zone}

Definition: Burckle (1972), p. 238. The base of this zone is placed immediately above the first evolutionary appearance of Pseudoeunotia doliolus. Thus, the zone is defined by the range of Pseudoeunotia doliolus. In this study, the base of this zone has not been defined.

Discussion: A modern flora is present throughout the zone, with Nitzschia marina, Coscinodiscus nodurifer, Pseudoeunotia doliolus, Rhizosolenia bergonii, and Roperia tesselata, all warm-water species.

Comparison with the diatom zonation of other workers: This zone is correlated with the Denticula seminae to Actinocyclus oculatus Zones of Koizumi (1973b), and the North Pacific Diatom Zones I to IV of Schrader (1973a).

Distribution: Found in the equatorial Pacific and Indian oceans and, to some extent in temperate latitudes of the Pacific according to Burckle (1972).

Adopted age: Pleistocene; from the Olduvai Event of the Matuyama Epoch to the present.

\section{Sea of Japan: Sites 299 to 302}

The biostratigraphic zonation of Koizumi (1973a, $1973 \mathrm{~b}$ ) is mainly based on the first appearances and the last occurrences of the marine planktonic species belonging to the genus Denticula, and on the species composition of the thanatocoenoses in time. Recently, Schrader (1973b) reviewed the taxonomy of the marine species of the genus Denticula and gave information on the stratigraphic distribution of new proposed species. Through this study the local ranges of following marine neritic species were recognized: Coscinodiscus pustulatus, Stephanopyxis horridus, Stephanopyxis innermis, Thalassiosira usachevii, and Thalassiosira zabelinae. By those two reasons, new zonal names were proposed here. The zones are listed from older to younger. Denticula kamtschatica Partial-Range Zone

Definition: Koizumi (1973b), p. 819.
Discussion: The base of this zone is not defined in this study. The zone as defined at Site 302 may be equivalent to the upper two-thirds of this zone in Leg 19 of the Deep Sea Drilling Project at high latitudes of the North Pacific based on the ranges of some selected species, and one of Site 301 is younger. The zone contains the range of Thalassiosira nativa. The ranges of Coscinodiscus temperi, Cosmiodiscus insignis, and Goniothecium tenue are included in the lower part of this zone. The earliest appearances of Thalassiosira zabelinae, Rhizosolenia curvirostris, and Thalassiosira nidulus, and the latest occurrence of Rouxia californica take place in the lower part. The first appearance of Actinocyclus ochotensis occurs in the upper portion of this zone.

Comparison with diatom zonation of other workers: This zone is correlated to the Complex VI in the Stage B of the Tyushevsk Formation, Kamchatka by Sheshukova-Poretzkaya (1967) and the North Pacific Diatom Zone X of Schrader (1973a).

Distribution: Found in the northern circum-Pacific sediments from Japan to California via the Bering Sea.

Adopted age: Early Pliocene(?); the middle part of the Gilbert Reversed Epoch based on the paleomagnetic stratigraphy of Burckle (1972) and the zonation of Schrader (1973a).

Denticula seminae v. fossilis-Denticula kamtschatica Concurrent-Range Zone

Definition: Koizumi (1973b), p. 819.

Discussion: The first appearance of Actinocyclus oculatus and Nitzschia cylindrius is observed in the lower part of this zone. Thalassiosira usachevii and Thalassiosira zabelinae have a tendency to become extinct during this zone in this area.

Comparison with diatom zonation of other workers: This zone is correlated with the North Pacific Diatom Zones IX to VII of Schrader (1973a).

Distribution: Found in the northern circum-Pacific sediments.

Adopted age: Middle Pliocene; from the upper part of the Gilbert Reversed Epoch to the lower part of the Gauss Normal Epoch. 
TABLE 8

Abundance and Stratigraphic Distribution of Diatoms, Site 301

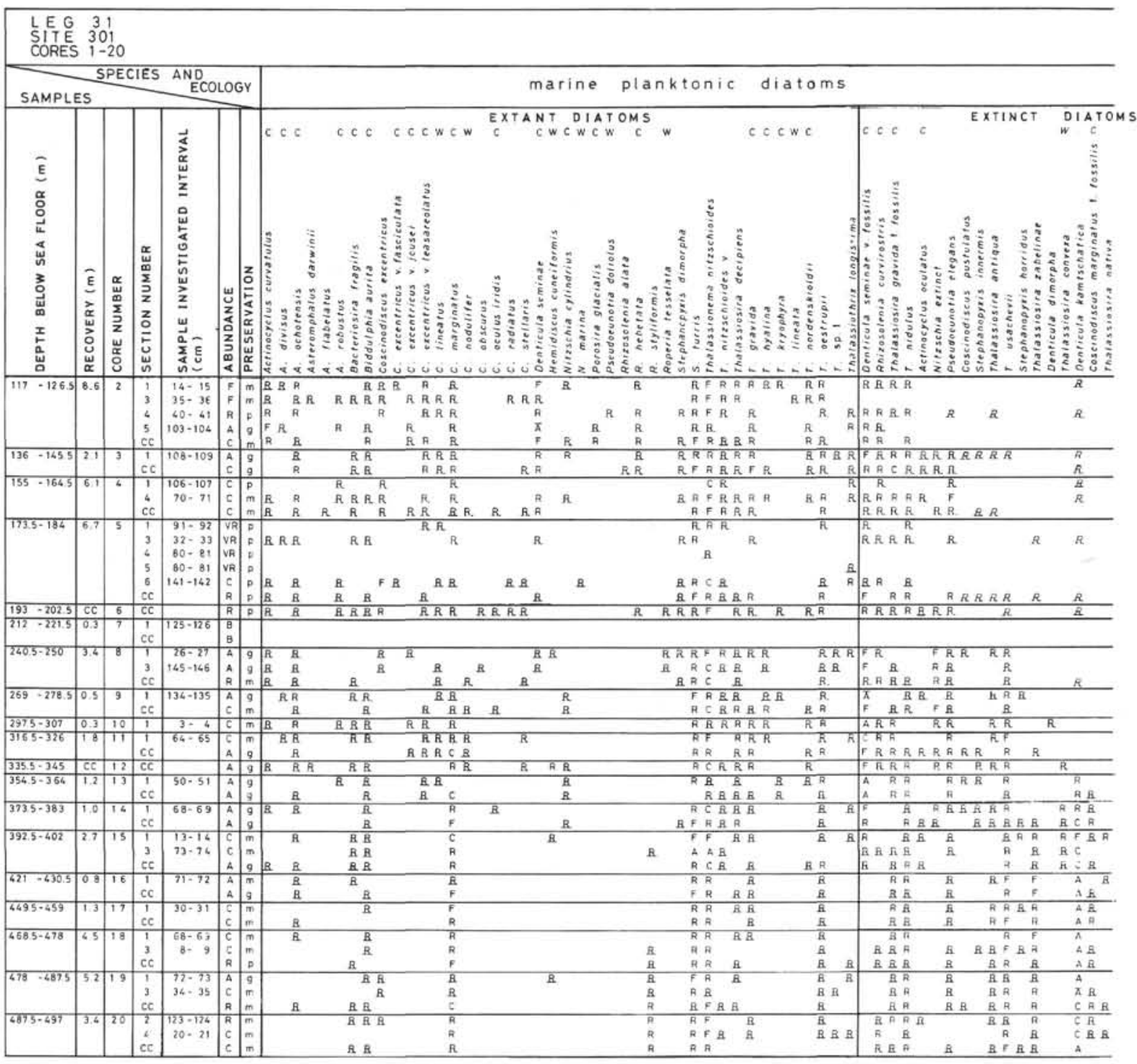

Denticula seminae v. fossilis Partial-Range Zone

Definition: This zone is equal to the Thalassiosira zabelinae Zone of Koizumi (1973b). The occurrence of Thalassiosira zabelinae was only sporadically observed throughout this zone, so the zonal name was changed. The base is defined as just after the youngest occurrence of the Denticula seminae v. fossilis-Denticula kamtschatica Zone which is defined by the extinction of Denticula kamtschatica. The top of this zone is defined by the latest occurrences of Thalassiosira antiqua, Coscinodiscus pustulatus, and Stephanopyxis innermis.

Discussion: Events within this zone are the latest occurrences of Coscinodiscus marginatus f. fossilis, and Thalassiosira convexa, and earliest appearance of Denticula seminae.

Comparison with diatom zonation of other workers: This zone is correlated with the North Pacific Diatom Zones VI to V of Schrader (1973a).

Distribution: Found in the northern circum-Pacific sediments.
Adopted age: Late Pliocene; from the Olduvai Event of the Matuyama Reversed Epoch to the upper part of the Gauss Normal Epoch.

Actinocyclus oculatus Partial-Range Zone

Definition: Koizumi (1973b), p. 819.

Discussion: The modern flora is present throughout this zone, with Actinocyclus curvatulus, Coscinodiscus excentricus vars., Porosira glacialis, Rhizosolenia hebetata f. hiemalis, Thalassiosira hyalina, Thalassiosira kryophyra, and Thalassiosira nordenskiöldii.

Comparison with the diatom zonation of other workers: This zone is correlated with the interval from the North Pacific Diatom Zone IV to the lowermost part of the North Pacific Diatom Zone II of Schrader (1973a).

Distribution: Found in the northern circum-Pacific sediments.

Adopted age: Early Pleistocene; from the Olduvai Event of the Matuyama Reversed Epoch to the Jaramillo Event of the Matuyama Reversed Epoch. 
TABLE 8 - Continued

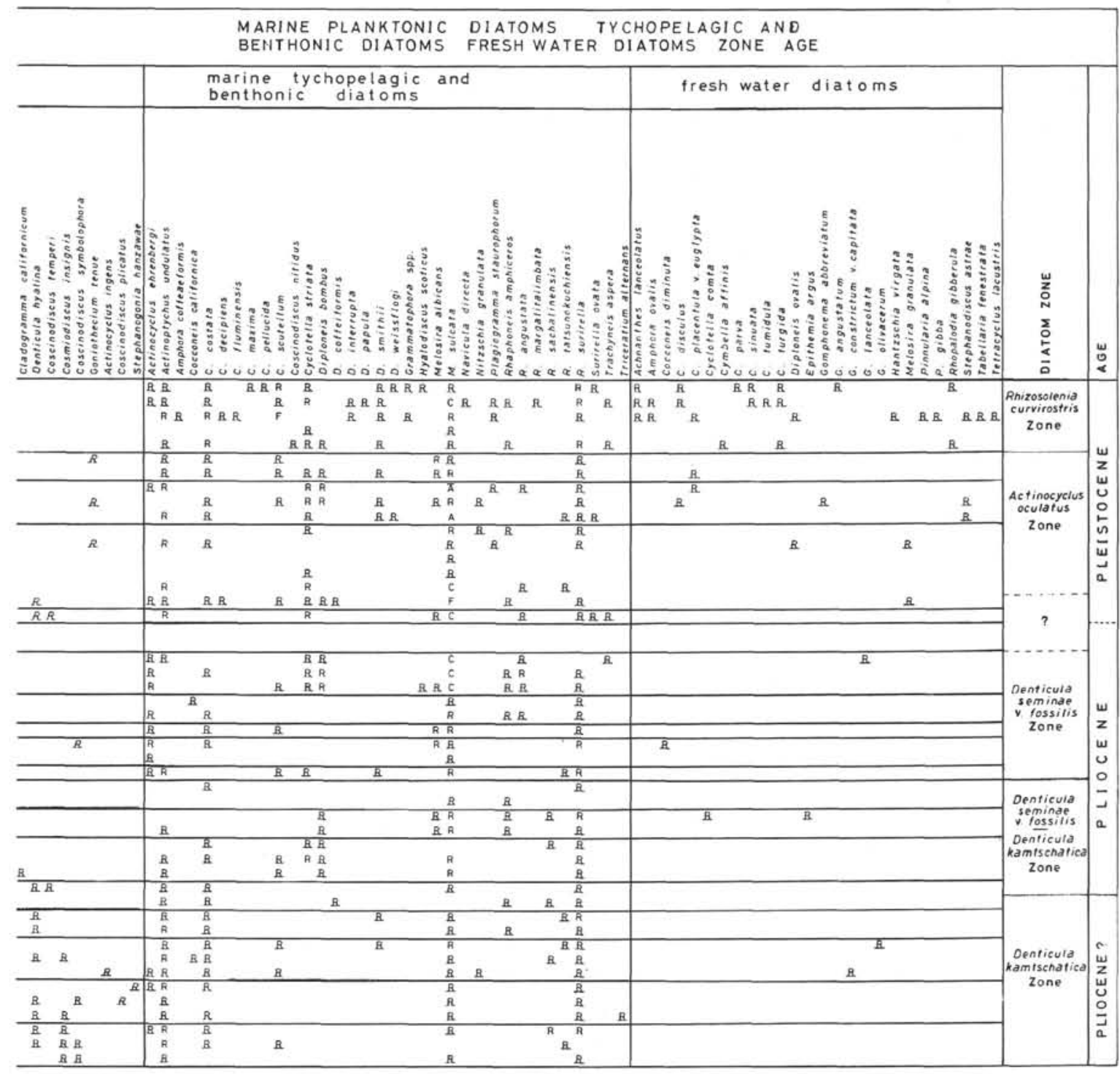

\section{Rhizosolenia curvirostris Partial-Range Zone}

Definition: Koizumi (1973b), p. 819.

Discussion: The extinctions of Nitzschia extincta, Nitzschia fossilis, and Nitzschia reinholdii are observed within this zone.

Comparison with the diatom zonation of other workers: This zone falls within the North Pacific Diatom Zone II of Schrader (1973a).

Distribution: Found in the northern circum-Pacific sediments.

Adopted age: Middle Pleistocene; the interval from the middle part of the Brunhes Normal Epoch to the base of the Jaramillo Event of the Matuyama Reversed Epoch.

\section{Denticula seminae Partial-Range Zone}

Definition: Koizumi (1973b), p. 820.

Discussion: This zone includes the taxa which form the "Subarctic Assemblage" or "Northwest Marginal Assemblage" of Kanaya and Koizumi (1966).
Comparison with the diatom zonation of other workers: This zone is correlated with the North Pacific Diatom Zone I of Schrader (1973a).

Distribution: Found in the northern circum-Pacific sediments.

Adopted age: Late Pleistocene to Recent; the interval from the middle part of the Brunhes Normal Epoch to the Recent.

A tabulation of the zonation and the intervals of rock samples studied is presented for each site in Table 10. Figure 5 indicates the results of the correlations among those sites.

\section{CORRELATION WITH OTHER DIATOM SECTIONS IN THE PACIFIC AREA}

A biostratigraphic zonation proposed by Burckle (1972) for the east equatorial Pacific is most useful in age assignments for the diatom zones because the occurrences of selected marine planktonic species are com- 


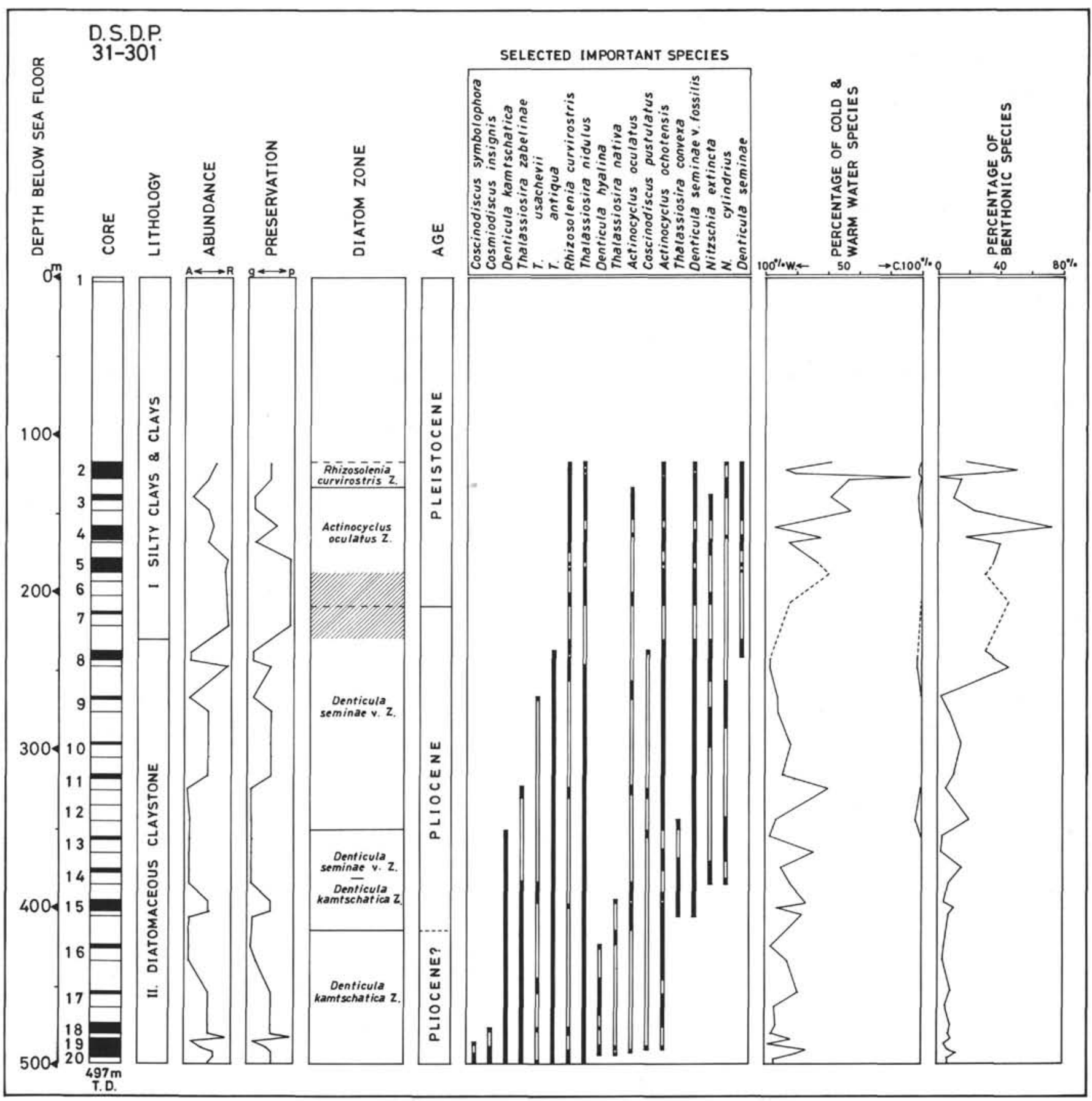

Figure 3. Stratigraphic variation of selected groups of species and ranges of selected planktonic species, Site 301. Black areas in the core column represent cored sequences and that in the ranges of selected species show where those species occurred.

pared with the paleomagnetic and the biostratigraphy based on other microfossils. The comparisons of time ranges of selected species in the subarctic deep-sea sediments of Leg 19 of the Deep Sea Drilling Project by Koizumi (1973b) with those from the east equatorial Pacific was not well established in Koizumi (1973b). However, there are only rare occurrences of the more common species between the diatom assemblages shown by Burckle (1972) and those by Koizumi (1973b) due to the difference in geographic provinces of living diatoms in each assemblage. According to Kanaya and Koizumi (1966), those assemblages are comparable to the "Equatorial Assemblage," and "Subarctic Assemblage" and "Northwest Marginal Assemblage" of the modern sediments in point of the species composition, respectively.

More recently, Schrader (1973b) established North Pacific Diatom Zones I to XXV based on the ranges of selected species for the sediments from Recent to middle Miocene at Site 173 in the northeast Pacific, Leg 18 of 
TABLE 9

Abundance and Stratigraphic Distribution of Diatoms, Site 302

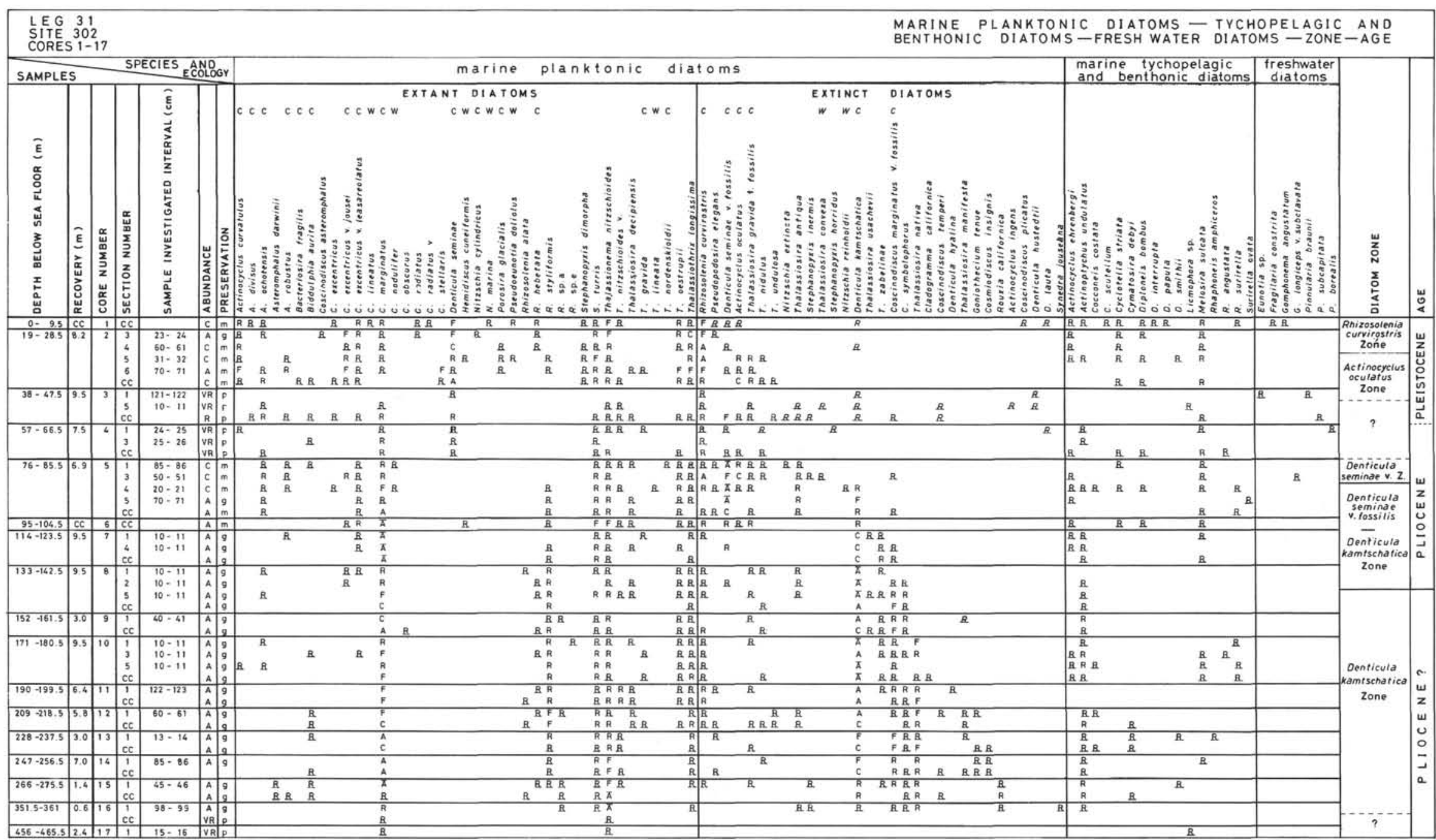




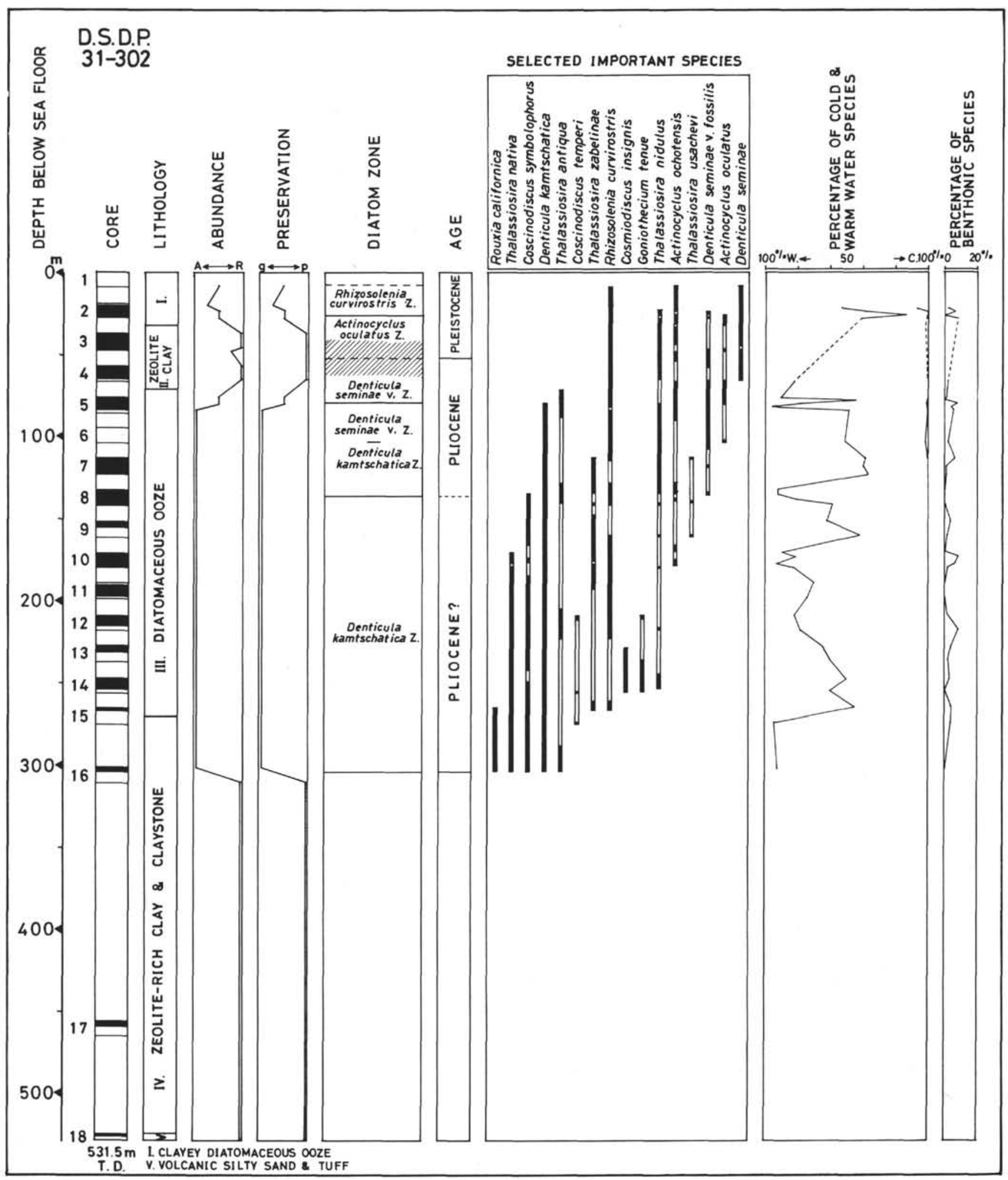

Figure 4. Stratigraphic variation of selected groups of species and ranges of selected planktonic species, Site 302. Black areas in the core column represent cored sequences and that in the ranges of selected species show where those species occurred. 
TABLE 10

Diatom Zonation and Rock Intervals of Samples Studied at Each Site, Leg 31, Deep Sea Drilling Project

\begin{tabular}{|c|c|c|c|c|c|c|c|c|c|}
\hline \multirow{2}{*}{\multicolumn{2}{|c|}{ AGE ZONE }} & \multicolumn{4}{|c|}{ SEA OF JAPAN } & \multicolumn{4}{|c|}{ SHIKOKU } \\
\hline & & 302 & 301 & 300 & 299 & ZONE & 298 & 297 & 296 \\
\hline \multirow{3}{*}{ 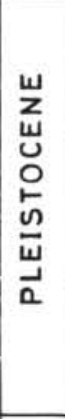 } & $\begin{array}{l}\text { Denticula } \\
\text { seminae } \\
\text { Zone }\end{array}$ & & & & $\begin{array}{c}1-1 \\
(2-3) \\
1 \\
2-c c\end{array}$ & \multirow{3}{*}{$\begin{array}{c}\text { Pseudoeunotia } \\
\text { doliolus } \\
\text { Zone }\end{array}$} & \multirow{3}{*}{$\begin{array}{c}1-C C \\
\mid \\
16-1) \\
(46-47)\end{array}$} & \multirow{3}{*}{$\begin{array}{l}1-C C \\
\mid \\
6-C C\end{array}$} & \multirow{3}{*}{$\begin{array}{c}\begin{array}{c}1-1 \\
(45-46)\end{array} \\
\mid \\
2-\mathrm{CC}\end{array}$} \\
\hline & $\begin{array}{c}\text { Rhizosolenia } \\
\text { curvirostris } \\
\text { Zone }\end{array}$ & $\begin{array}{c}1-C C \\
\mid \\
2-4 \\
(60-61)\end{array}$ & $\begin{array}{c}2-1 \\
\left(\begin{array}{c}14-15 \\
1\end{array}\right) \\
2-c c\end{array}$ & $\begin{array}{c}1-c c \\
1 \\
2-c c\end{array}$ & $\begin{array}{c}3-4 \\
(10-11) \\
1 \\
10-5 \\
(104-105)\end{array}$ & & & & \\
\hline & $\begin{array}{c}\text { Actinocyclus } \\
\text { oculatus } \\
\text { Zone }\end{array}$ & $\begin{array}{c}(32-5 \\
(31-32) \\
1 \\
3-c c\end{array}$ & $\begin{array}{c}\left(108-1{ }^{3}-1\right. \\
\mid \\
6-C C\end{array}$ & & $\begin{array}{c}10-C C \\
\mid \\
17-4 \\
(75-76)\end{array}$ & & & & \\
\hline \multirow{2}{*}{$\begin{array}{l}u \\
z \\
w \\
u \\
0 \\
\Xi \\
0\end{array}$} & $\begin{array}{l}\text { Denticula } \\
\text { seminae } \\
\text { v. fossilis } \\
\text { Zone }\end{array}$ & $\begin{array}{c}4-1 \\
(24-25) \\
1 \\
(50-53 \\
(50)\end{array}$ & $\begin{array}{c}7-1 \\
(125-126) \\
\mid \\
12-c c\end{array}$ & & $\begin{array}{c}17-C C \\
\mid \\
29-C C\end{array}$ & & & & \\
\hline & $\begin{array}{c}\text { Denticula } \\
\text { seminae v. } \\
\text { Denticula } \\
\text { kamtschatica } \\
\text { Zone }\end{array}$ & $\begin{array}{c}5-4 \\
(20-21) \\
1 \\
8-22 \\
(10-11)\end{array}$ & $\begin{array}{c}13-1 \\
(50-51) \\
1 \\
16-11 \\
(71-72)\end{array}$ & & $\begin{array}{c}30-1 \\
(22-23) \\
\mid \\
30-c c\end{array}$ & & & & \\
\hline 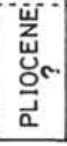 & $\begin{array}{l}\text { Denticula } \\
\text { kamtschatica } \\
\text { Zone }\end{array}$ & $\begin{array}{c}8-5 \\
(10-11) \\
\mid \\
16-1 \\
(98-99)\end{array}$ & $\begin{array}{c}16-\mathrm{CC} \\
\mid \\
20-\mathrm{CC}\end{array}$ & & $35-\mathrm{CC}$ & & & & \\
\hline
\end{tabular}

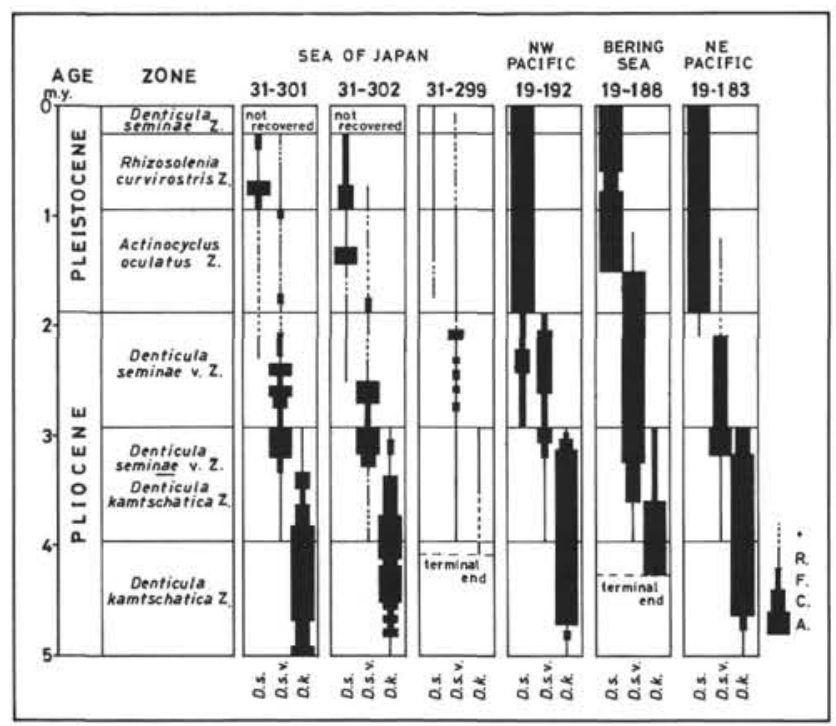

Figure 5. Stratigraphic ranges of three marine species of the genus Denticula and zonal subdivisions at Sites 183, 188, and 192 of Leg 19 and Sites 299, 301, and 302 of Leg 31 of the Deep Sea Drilling Project. Abbreviation: D. s., Denticula seminae; D. s. $v$., Denticula seminae $v$. fossilis; D. k., Denticula kamtschatica; $R$, rare; $F$, few, $C$, common; $A$, abundant. the Deep Sea Drilling Project and correlated the North Pacific diatom zones with the east equatorial Pacific zonation of Burckle (1972). The North Pacific diatom zonation of Schrader (1973a) is apparently local and is not applied over the northern circum-Pacific region due to the minute subdivisions of this zonation.

Comparison of the zones used in this study with the zonation by Burckle (1972) for the east equatorial Pacific was based on the top and bottom of the ranges of selected planktonic species, in turn allowing age assignments to be made for zones used during Leg 31 of the Deep Sea Drilling Project. Correlations were also made with land and oceanic sections at the following localities of the North Pacific (Figure 6); Japan (Koizumi, 1973a); Kamchatka and Sakhalin (Sheshukova-Poretzkaya, 1967); northwest Pacific and northeast Pacific, Leg 19 of the Deep Sea Drilling Project (Koizumi, 1973b); central North Pacific (Donahue, 1970; Koizumi, 1973b); and California (Simonsen and Kanaya, 1961). Koizumi (1973b) earlier summarized the stratigraphic sequences of diatomaceous strata and the diatom stratigraphies at those localities, separately.

Figure 7 shows the results of the correlation among diatom zonations by other workers. On the column of eastern North Pacific by Schrader (1973a), selected species for the key correlating with the east equatorial Pacific zonation of Burckle (1972) are arranged on the right side, and the species used as keys for the correlation with the western North Pacific zonation of Koizumi (1973b) are arranged on the left side. 


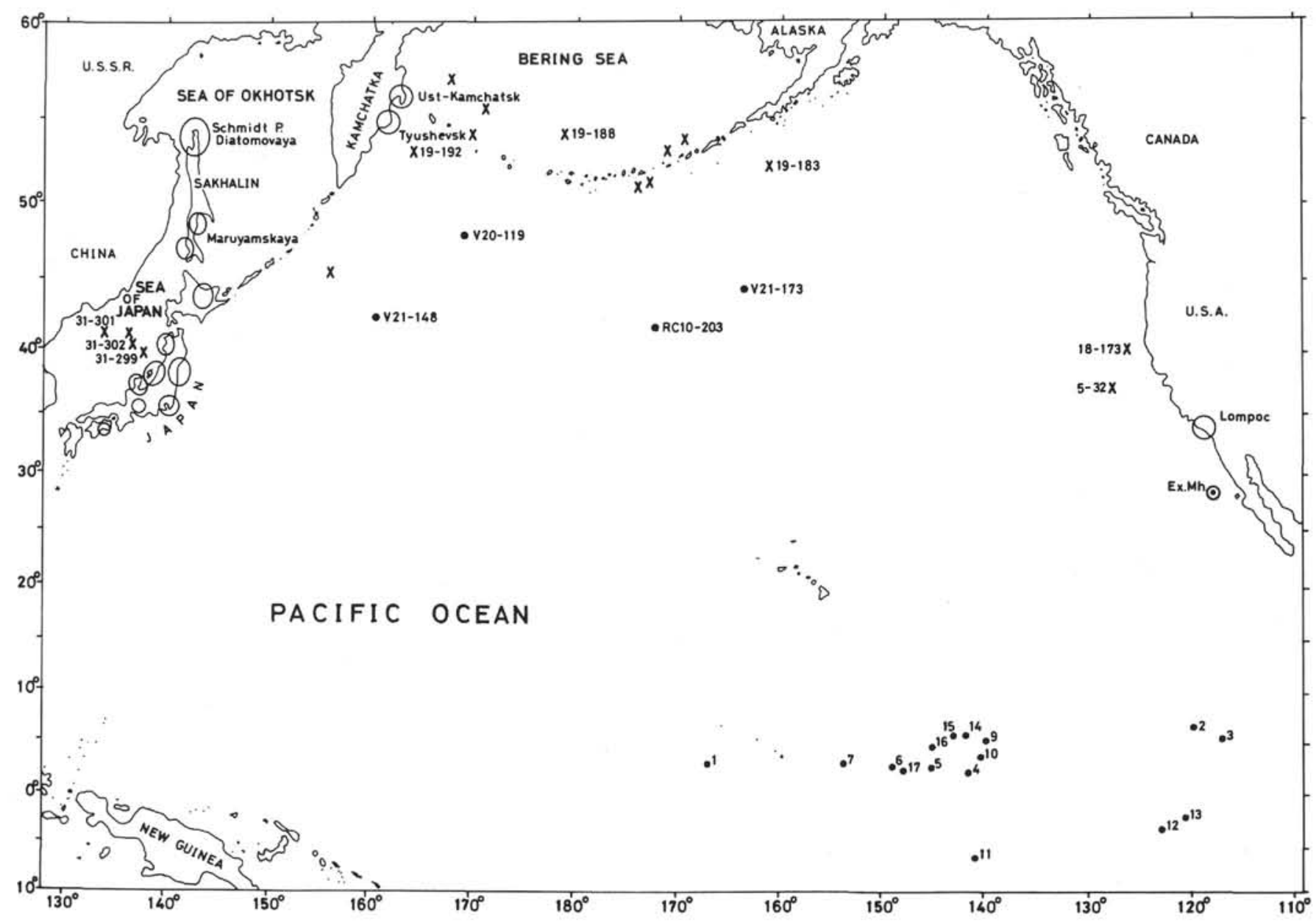

Figure 6. Location map of sediment cores in the North Pacific Ocean and of land-based sequencies in the northern circumPacific region used in this study.

\section{EPOCH AND AGE ASSIGNMENTS FOR THE DIATOM ZONE IN THIS STUDY}

The correlations with the dated deep-sea cores, late Pliocene to Recent cores from the central North Pacific (Donahue, 1970; Koizumi, 1973b) and especially late Miocene to Recent cores from the east equatorial Pacific (Burckle, 1972) permitted determination of the geological age of diatom zones represented by diatombearing samples explained in this study. The age assignments for those zones that were deduced in this study differ from Koizumi (1973a, 1973b).

Koizumi (1973a) once presented the ranges of marine planktonic diatoms and the tentative diatom zonation using ranges for the interval from middle Miocene to Pliocene in Japan. Koizumi (1973a) pointed out that the age assignments for the sequences in several areas based on the diatom zonation differ remarkably from the usual age assignments for them, in which was already stated by Burckle (1971) for the Oga sequence. Recently, planktonic foraminiferal zonation in Japan, which is the first means Koizumi (1973a) used in order to position stratigraphically diatomaceous samples into the chronostratigraphic framework in Japan, was newly proposed by Maiya et al. (in press) and the age for these zones is remarkably younger in comparison with Saito (1963), and Shinbo and Maiya (1969).

Burckle (1972) and Opdyke (1972) placed the epoch and age boundaries on the paleomagnetic stratigraphy with relating to the standard reference sections of Europe.

1) Middle- late Miocene (Langhian-Tortonian) boundary falls within the Geomagnetic Epoch 11. This is Globorotalia (T.) continuosa Zone of Blow (1969) and the Globorotalia menardii Zone of Bolli (1957). Discoaster hamatus appears to be restricted to this zone (Wilcoxon and Bramlette, 1967).

2) Miocene-Pliocene boundary is placed at the end of the Geomagnetic Epoch 5 at an age of about 5.1 m.y.B.P. when the boundary is interpreted as the beginning of Tabianian based on faunal criteria by Saito (1969). This epoch boundary is correlated to near the N.17-N.18 of foraminiferal standard zone of Blow (1969).

3) Pliocene-Pleistocene boundary occurs within sediments deposited during the Olduvai Event of the Matuyama Reversed Epoch.

These boundaries are proposed also by Berggren (in preparation), and used in this report. 


\section{PALEOENVIRONMENTAL INTERPRETATIONS}

\section{Paleoclimatic Interpretation}

Climatic fluctuations based on the percentage of the cold-water species were analyzed for the Holocene to early Pliocene interval at Sites 299 to 302 of the Sea of Japan. A diatom temperature (Td) value by Kanaya and Koizumi (1966) could not be used in this study because the occurrences of the warm-water species were rare to a few throughout those sequences.

Generally speaking, the cold-water species are more dominant in the upper part than in the lower part of the section at each site. In the upper part, the percentage of the cold-water species gradually increases from the upper part of the Actinocyclus oculatus Zone (about 1.2 m.y.B.P.) to the lower part of the Rhizosolenia curvirostris Zone (about 0.85 m.y.B.P.), and it has the maximum percentage at that position. This aspect corresponds with the result in the northern North Pacific, Leg 19 of the Deep Sea Drilling Project (Koizumi, 1973b).

The cold-water species prevail throughout the lower Pliocene portion of the section at Site 302 (Figure 4). This may be caused by the high primary productivity via the upwelling of the cold, nutrient-rich bottom water due to geographical features of the Yamato Rise (Figure $8)$.

\section{Paleosedimentological Interpretation}

As suggested by the greater amount of terrigenous materials, several layers of size-graded sands and silts, and displaced benthonic foraminifera, the occurrences of the tychopelagic-benthonic, fresh-water and reworked extinct diatom species throughout the sections at Sites 298 and 299 may have been brought in by turbidity currents from adjacent land masses (Figure 8).

In Sites 299 to 302 in the Sea of Japan, the remarkable decrease in abundance of diatoms, and increase in the percentage of the benthonic species, were observed both above and below the Pliocene-Pleistocene boundary (between Denticula seminae v. fossilis Zone and Actinocyclus oculatus Zone). In this part of Site 302 there may be a slight unconformity between the upper part of the Denticula seminae v. fossilis Zone and the lower part of the Actinocyclus oculatus Zone. This presumably means that the first significant glacial lowering of sea level and the tectonic uplift of periphery including the Sea of Japan occurred at the beginning of the Pleistocene.

\section{Sedimentation Rates}

The sedimentation curves calculated on the basis of the diatom zonation show two phases during the Pleistocene and Pliocene intervals in terms of variable rates of sedimentation at each site (Figure 9).

Sedimentation rates correlate with the amounts of pelagic debris and hemipelagic terrigenous clastics, and the abundance of diatoms within a sample indicates the amount of dilution by the terrigenous materials, assuming a constant production and sedimentation of pelagic debris.

All sites have the highest sedimentation $(150 \mathrm{~m} / \mathrm{m} . \mathrm{y}$. during the Pliocene interval. The cold climate during this interval may have induced greater planktonic productivity, especially for Site 302 where there is increased upwelling. Intervals cored at Sites 299 and 301 are characterized by the mixture of the fan deposit directly from shelf margins due to the lowered sea level, and pelagic debris containing common diatom frustules. Sites 299 and 301 have a moderate sedimentation rate of $130 \mathrm{~m} / \mathrm{m} . \mathrm{y}$., and Site 302 has the lowest rate of 25 $\mathrm{m} / \mathrm{m} . \mathrm{y}$. during the Pleistocene interval. During the Pleistocene interval, pelagic sediments greatly decreased as compared to the Pliocene, but eustatically lowered sea level allowed more direct and greater transport of terrigenous clastic and coarser turbidites to the basin from the exposed shelf margin.

\section{SYSTEMATIC SECTION: FLORAL REFERENCES}

References are given for those taxa from Sites 296 through 302, Leg 31 of the Deep Sea Drilling Project. They are arranged alphabetically, separately under the marine planktonic, marine tychopelagic and benthonic, and fresh-water diatoms. The taxa that were treated by Hustedt $(1930,1962 \mathrm{a}, 1962 \mathrm{~b}, 1971)$ are referred directly to that work. For the taxa that were treated by Hustedt, references are made as closely as possible to the original descriptions. Additional references are selected from remarks and illustrations which were helpful for the present study. Among those listed here, most of the marine planktonic species, which are useful for the diatom zonation, are illustrated; their plate and figure numbers are shown in parentheses.

\section{Marine Planktonic Diatoms}

Actinocyclus curvatulus Jan., in Schmidt, 1876: Hustedt, 1962a, p. 538, fig. 307; Hustedt, 1958, p. 129, pl. 8, fig. 82, 83; Koizumi, 1968, p. 207, pl. 32, fig. 1, 2; Koizumi, 1973b, p. 831, pl. 1, fig. 1-6; Schrader, 1973a, p. 701, pl. 19, fig. 2. (Plate 2, Figures 7-10)

Actinocyclus divisus (Grun.) Hust., Hustedt, 1958: p. 129, pl. 8, fig. 81; Koizumi, 1968, p. 207, pl. 32, fig. 3; Koizumi, 1973b, p. 831, pl. 1, fig. 7-12. (Plate 2, Figures 1-4)

Actinocyclus ellipticus Grun., 1881: Hustedt, 1962a, p. 533, fig. 303. Actinocyclus ingens Ratt., Rattray, 1890: p. 149, pl. 11, fig. 7; Sheshukova-Poretzkaya, 1967 , p. 194, pl. 29, fig. 8, pl. 30, fig. 1a-e, Koizumi, 1968, p. 207, pl, 32, fig. 5, 6; Kanaya, 1971, p. 554, pl. 40.6, fig. 1-8; Koizumi, 1973b, p. 831, pl. 1, fig. 13, 14, pl. 2, fig. 1, 2.

Actinocyclus ochotensis Jousé, 1968: p. 17, pl. 2, fig. 2-5; Donahue, 1970, p. 135, pl. 2, fig. 2-5; Koizumi, 1973b, p. 831, pl. 2, fig. 3-7; Schrader, 1973a, p. 701, pl. 18, fig. 8, 17, pl. 19, fig. 6; Koizumi and Kanaya, in press, pl. 1, fig. 24. (Plate 2, Figures 11-13)

Actinocyclus oculatus Jousé, 1968: p. 18, pl. 2, fig. 6, 7; Koizumi, 1968, p. 208 , pl. 32 , fig. 11-14; Donahue, 1970, p. 135, pl. 2, fig. 6,7 Koizumi, 1973b, p. 831, pl. 2, fig. 8, 9. (Plate 2, Figures 14-17)

Asteromphalus darwinii Ehr., 1844: Schmidt, 1876, pl. 38, fig. 16; Wornardt, 1967, p. 51, fig. 82; Koizumi, 1968, p. 209, pl. 32, fig. 7; Hanna, 1970, p. 180, fig. 90. Synonyms: As Asteromphalus $\mathrm{cf}$. robustus Castrac., Schrader, 1973a, p. 702, pl. 21, fig. 7.

Asteromphalus flabellatus (Bréb.) Grev., 1859: Hustedt, 1962a, p. 498, fig. 279; Koizumi, 1968, p. 209. pl. 32, fig. 16.

Asteromphalus robustus Castr., 1875: Hustedt, 1962a, p. 496, fig. 278; Sheshukova-Poretzkaya, 1967, p. 190, pl. 29, fig. 2; Schrader, 1973a, p. 702 , pl. 21 , fig. 4,5 .

Bacteriosira fragilis Gran, 1900: Hustedt, 1962a, p. 544, fig. 310; Jousé, 1962, pl. 2, fig. 15; Sheshukova-Poretzkaya, 1967, p. 202, pl. 33, fig. 3a, b; Schrader, 1973a, p. 702, pl. 16, fig. 7. (Plate 2, Figures $5,6)$

Biddulphia aurita (Lyng.) Bréb. and God., 1838: Hustedt, 1962a, p. 846, fig. 501; Cupp, 1943, p. 161, fig. 112A; SheshukovaPoretzkaya, 1967, p. 214, pl. 34, fig. 5; Wornardt, 1967, p. 60, fig. 113.

Cladogramma californica Ehr., 1854: Van Heurck, 1880, pl. 83, fig. 8, 9; Kanaya, 1959, p. 87, pl. 6, fig. 1; Wornardt, 1967, p. 42, fig. 64; Koizumi, 1968, p. 210, pl. 32, fig. 19. Synonyms: As Cladogramma dubium Lohman, Schrader, 1973a, p. 702, pl. 13, fig. 17, 18, 21. 


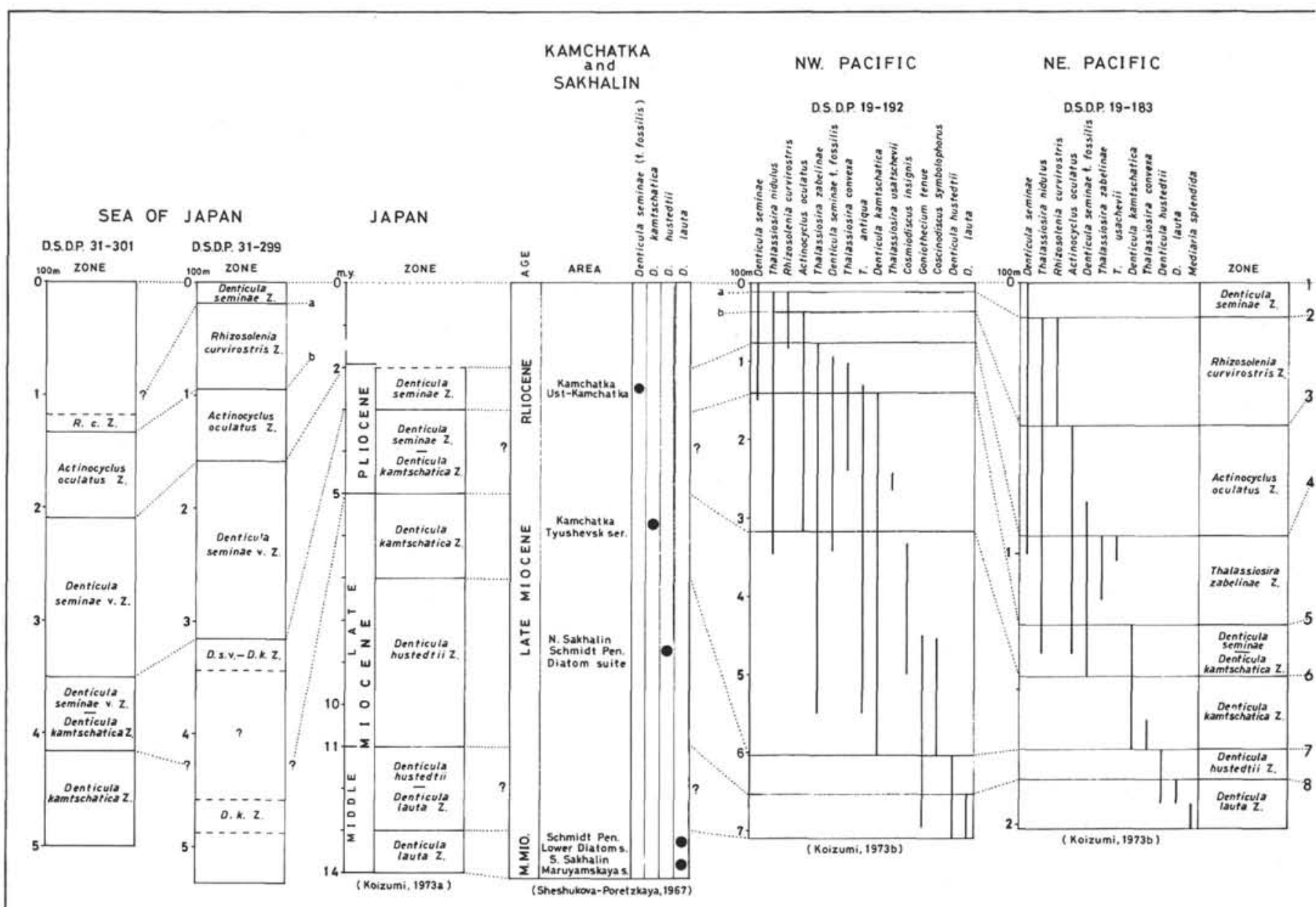

Figure 7. Correlation of the diatom zones in this report with the Japan diatom zonation of Koizumi (1973a), diatomaceous strata in Kamchatka and Sakhalin by Sheshukova-Poretzkaya (1967), diatom zonation in Leg 19 of the Deep Sea Drilling Project by Koizumi (1973b), central North Pacific diatom zonation of Donahue (1970) and Koizumi (1973b), diatomaceous strata in California by Simonsen and Kanaya (1961), northeastern Pacific in Leg 18 of the Deep Sea Drilling Project by Schrader (1973a), and with the east equatorial Pacific diatom zonation of Burckle (1972) based on top and bottom in the ranges of selected diatom species.

Coscinodiscus asteromphalus Ehr., 1844: Hustedt, 1962a, p. 452, fig. 250.

Coscinodiscus excentricus Ehr., 1839: Hustedt, 1962a, p. 388, fig. 201; Cupp, 1943, p. 52, fig. 1; Koizumi, 1968, p. 211, pl. 32, fig. 23, 24; Koizumi, 1973b, p. 831, pl. 2, fig. 11, 12. Remarks: After the microscopical examination, I found Fryxell and Hasle (1972) so it is necessary to check taxonomically this species in those materials used here. (Plate 2, Figures 18, 19)

Coscinodiscus excentricus Ehr. var. fasciculata Hustedt, 1962: 1962a, p. 390, fig. 202; Koizumi, 1973b, p. 831, pl. 2, fig. 13-16. (Plate 2, Figure 20)

Coscinodiscus excentricus Ehr. var. jousei Kanaya, in Kanaya and Koizumi, 1966: p. 125; Koizumi, 1973b, p. 832, pl. 3, fig. 1-6. Remarks: Margin relatively broad, $1.5-2.5 \mu$ in width, with strong radial striae, 13-16 in $10 \mu$. A few to several small pores near center. Valve mantle well developed, which is seen as darker ring surrounding the outer border of valve. (Plate 3, Figures 1-4)

Coscinodiscus excentricus Ehr. var. leasareolatus Kanaya, in Kanaya and Koizumi, 1966: p. 125; Koizumi, 1973b, p. 832, pl. 3, fig. 7-11.
Remarks: Valve depressed in center. Meshwork of areolae tends to be loose in the center of valve, a pore and a few smaller subangular areolae in the center. Margin narrow, about $1 \mu$ in width. (Plate 3, Figure 5)

Coscinodiscus lineatus Ehr., 1938: Hustedt, 1962a, p. 392, fig. 204; Cupp, 1943, p. 53, fig. 15a-c; Koizumi, 1968, p. 211, pl. 32, fig. 26.

Coscinodiscus marginatus Ehr., 1843: Hustedt, 1962a, p. 416, fig. 223; Cupp, 1943, p. 55, fig. 19; Sheshukova-Poretzkaya, 1967, p. 156 , pl. 11, fig. 9, pl. 17, fig. $4 \sigma$, B, pl. 18, fig. $1 \sigma$, 2, 1e; Koizumi, 1968 , p. 211 , pl. 33, fig. 3a, b. (Plate 3, Figure 6)

Coscinodiscus marginatus Ehr. forma fossilis Jousé, 1961: 1961c, p. 68, pl. 3, fig. 7, 8; Koizumi, 1973b, p. 832, pl. 3, fig. 12-14; Schrader, 1973a, p. 703, pl. 20, fig. 12. (Plate 3, Figure 7)

Coscinodiscus nodulifer Schmidt, 1878: Hustedt, 1962a, p. 426, fig. 229; Kolbe, 1954, p. 33, pl. 3, fig. 35-37; Hendey, 1964, p. 77, pl. 22, fig. 10; Kanaya, 1971, p. 555, pl. 40.3, fig. 1-4. (Plate 3, Figures 11, 12) Coscinodiscus obscurus Schmidt, 1878: Hustedt, 1962a, p. 418, fig. 224 a, b; Sheshukova-Poretzkaya, 1967, p. 164, pl. 23, fig. 1.

Coscinodiscus oculus-iridis Ehr., 1839: Hustedt, 1962a, p. 454, fig. 252; Kanaya, 1959, p. 82, pl. 4, fig. 7; Hendey, 1964, p. 78, pl. 24, fig. 1; 


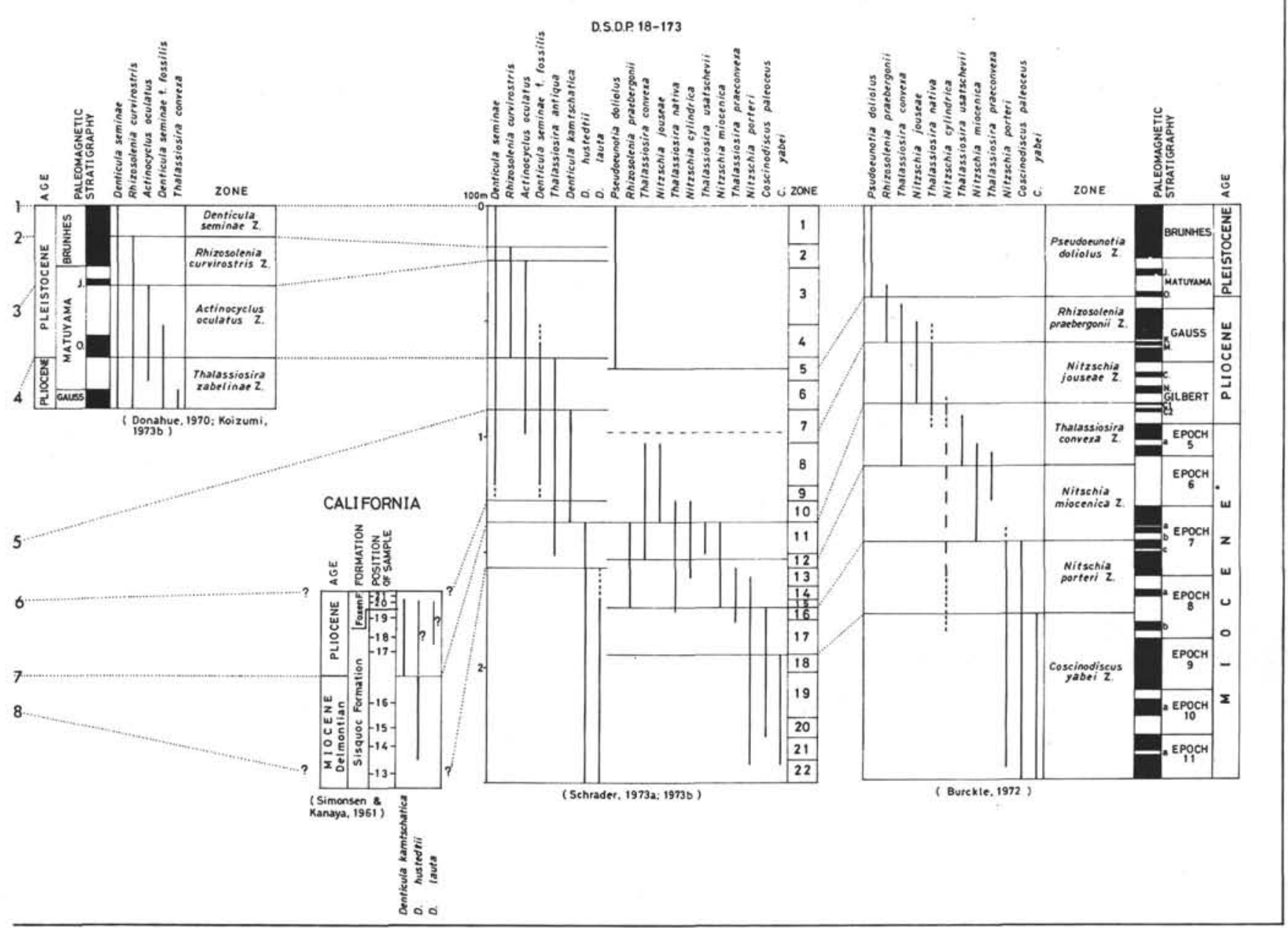

\section{Figure 7. (Continued).}

Sheshukova-Poretzkaya, 1967, p. 160, pl. 21, fig. 1; Wornardt, 1967 , p. 28 , fig. 34 , 35; Koizumi, 1968, p. 211, pl. 33, fig. 5, 6. Coscinodiscus plicatus Grun., Grunow, 1884: p. 86, pl. 3, fig. 10, 27; Kolbe, 1954, p. 34, 35, no illustration; Kanaya, 1971, p. 555, pl. 40.4, fig. 4-6; Schrader, 1973a, p. 703, pl. 6, fig. 23.

Coscinodiscus pustulatus Mann, 1907: p. 257, pl. 48, fig. 3; Hanna, 1970 , p. 185, fig. 12, 19, 20; Koizumi, 1972, p. 350, pl. 43, fig. 12; Koizumi, 1973b, p. 832, pl. 4, fig. 1-4. (Plate 3, Figures 8-10)

Coscinodiscus radiatus Ehr., 1839: Hustedt, 1962a, p. 240, fig. 225; Cupp, 1943, p. 56, fig. 20; Sheshukova-Poretzkaya, 1967, p. 153, pl. 17, fig. 2; Hanna, 1970, p. 185 , fig. 4 , 8, 17.

Coscinodiscus radiatus Ehr. var. 1, in Kanaya and Koizumi, 1966, p. 126. Remarks: This variety has a few interstitial meshes on a valve which otherwise is identifiable with Coscinodiscus radiatus Ehr. (Plate 3, Figures 13, 14)

Coscinodiscus stellaris Rop., 1858: Hustedt, 1962a, p. 396, fig. 207; Cupp, 1943, p. 53 , fig. 16; Koizumi, 1968, p. 212, pl. 33, fig. 11 .

Coscinodiscus symbolophorus Grun., Grunow, 1884: p. 82, pl. 4, fig. 36; Sheshukova-Poretzkaya, 1967, p. 167, pl. 22, fig. 3a- $\sigma$; Schrader, 1973a, p. 703, pl. 22, fig. 8, 9. Synonyms: As Coscinodiscus stellaris Rop. var. symbolophora (Grun.) Joerg., 1905: Hustedt, 1962a, p. 396, fig. 208a, b; Koizumi, 1973b, p. 832, pl. 4, fig. 5, 6.

Coscinodiscus tabularis Grun., 1884: Hustedt, 1962a, p. 427, fig. 230; Koizumi, 1968, p. 212, pl. 33, fig. 10.

Coscinodiscus temperi Brun, in Brun and Tempère, 1889: p. 33, pl. 8, fig. 2; Kanaya, 1959, p. 84, pl. 4, fig. 8; Koizumi, 1968, p. 212, pl. 32, fig. 28; Koizumi, 1973c, p. 134, pl. 20, fig. 9a, b; Schrader, 1973a, p. 704 , pl. 6 , fig. 18,19 , pl. 7 , fig. $1-5,8,9$.
Cosmiodiscus insignis Jousé, 1961: p. 67, pl. 2, fig. 8; SheshukovaPoretzkaya, 1967, p. 175, pl. 25, fig. 2a, b; Hanna, 1970, p. 186, fig. 9-11, 30, 32; Koizumi, 1973b, p. 832, pl. 4, fig. 7-11.

Denticula dimorpha Schrader, 1973: 1973a, p. 704, pl. 1, fig. 37-46; Schrader, 1973b, p. 418, pl. 1, fig. 16, 17. (Plate 1, Figures 27, 28)

Denticula hustedtii Simonsen and Kanaya, 1961: p. 501, pl. 1, fig. $19-$ 25; Sheshukova-Poretzkaya, 1967, p. 301, pl. 47, fig. 10, pl. 48, fig. $5 \mathrm{a}-\Gamma$; Kanaya, 1971, p. 555, pl. 40.5, fig. 13, 14; Koizumi, 1973b, p. 832, pl. 5, fig. 18-23; Schrader, 1973a, p. 704, pl. 2, fig. 28-34, 3647.

Denticula hyalina Schrader, 1973: 1973a, p. 704, pl. 1, fig. 12-22; Schrader, 1973b, p. 418, pl. 1, fig. 10, 22; Koizumi and Kanaya, in press, pl. 1, fig. 7, 8. (Plate 1, Figures 21-26)

Denticula kamtschatica Zabelina, 1934: Simonsen and Kanaya, 1961, p. 503, pl. 1, fig. 14-18; Sheshukova-Poretzkaya, 1967, p. 300, pl. 47 , fig. $9 \mathrm{a}-\sigma$, pl. 48 , fig. $4 \mathrm{a}-\delta$; Koizumi, 1968 , p. 213 , pl. 34 , fig. $7-$ 10; Koizumi, 1972, p. 350, pl. 42, fig. 12, 13; Koizumi, 1973b, p. 832, pl. 5, fig. 14-17; Schrader, 1973a, p. 705, pl. 2, fig. 1-13; Schrader, 1973b, p. 418, pl. 1, fig. 7, 8. (Plate 1, Figures 13-20)

Denticula lauta Baill., 1854: Simonsen and Kanaya, 1961, p. 500, pl. 1, fig. 1-8; Sheshukova-Poretzkaya, 1967, p. 299, pl. 47, fig. 8a- $\sigma$, pl. 48 , fig. 3a- $\delta$; Koizumi, 1968 , p. 213 , pl. 34 , fig. $11 \mathrm{a}-12$ b; Kanaya, 1971 , p. 555 , pl. 40.5 , fig. 11 ; Koizumi, 1973 b, p. 832 , pl. 5 , fig. $24-$ 28; Schrader, 1973a, p. 705, pl. 2, fig. 14-25, 35; Schrader, 1973b, p. 419, pl. 1, fig. 11, 20, 23, 24.

Denticula nicobarica Grun., 1868: Simonsen and Kanaya, 1961, p. 503, pl. 1, fig. 11-13; Schrader, 1973a, p. 705, pl. 1, fig. 31-35; Schrader, 1973b, p. 419, pl. 1, fig. 25-27. 


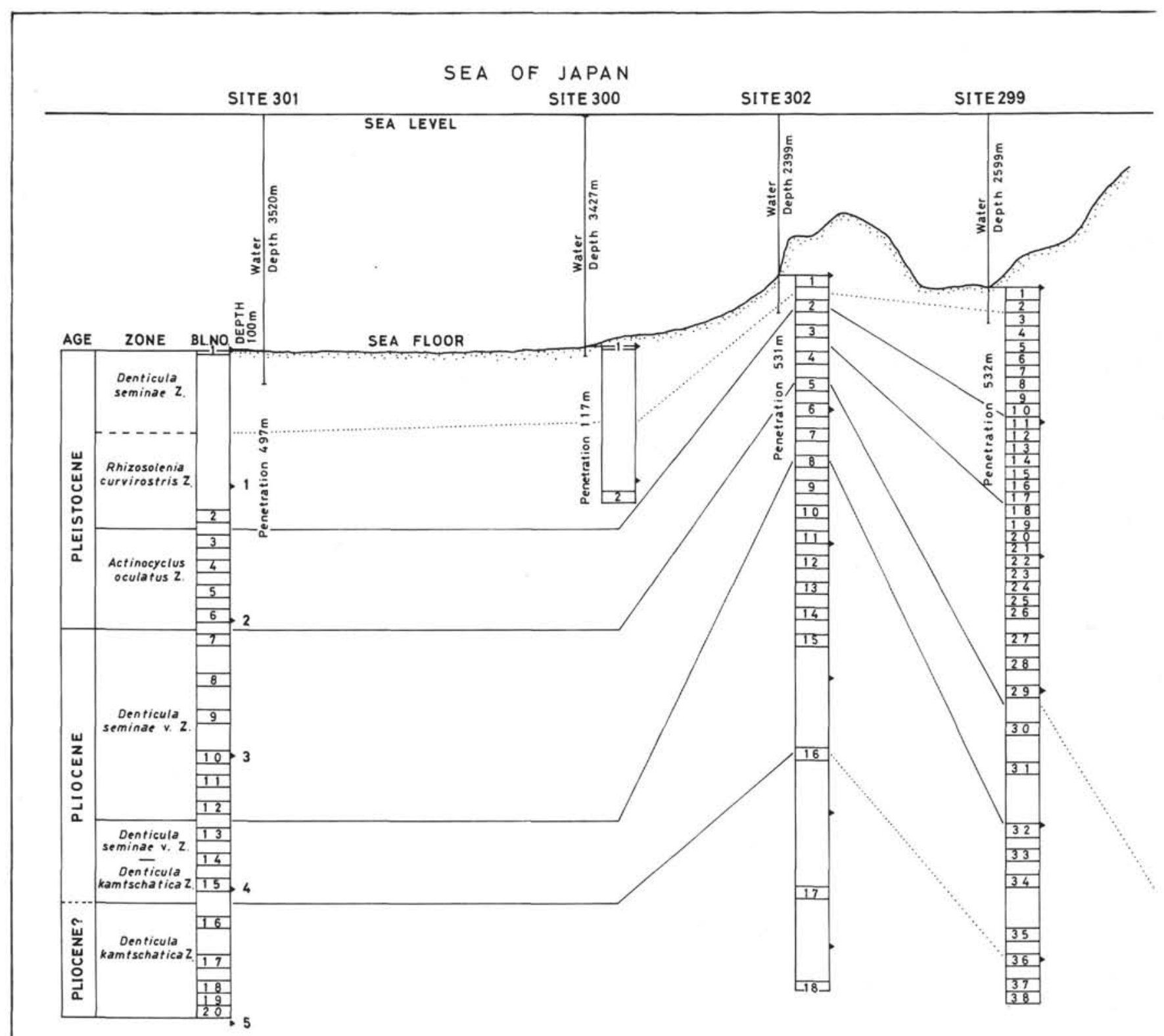

Figure 8. Comparison of thickness of the diatom zones at each site, Leg 31 of the Deep Sea Drilling Project. 


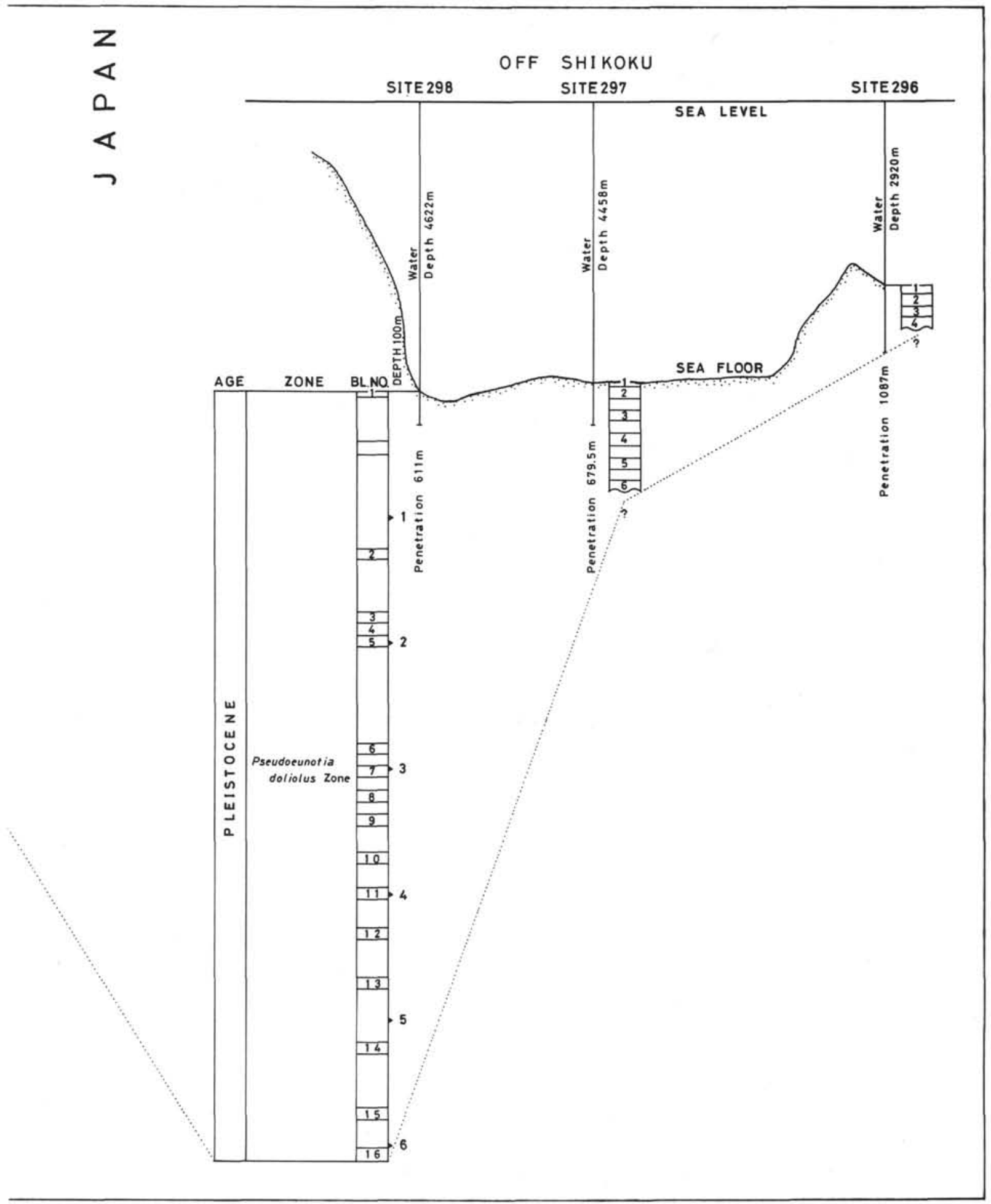

Figure 8. (Continued). 


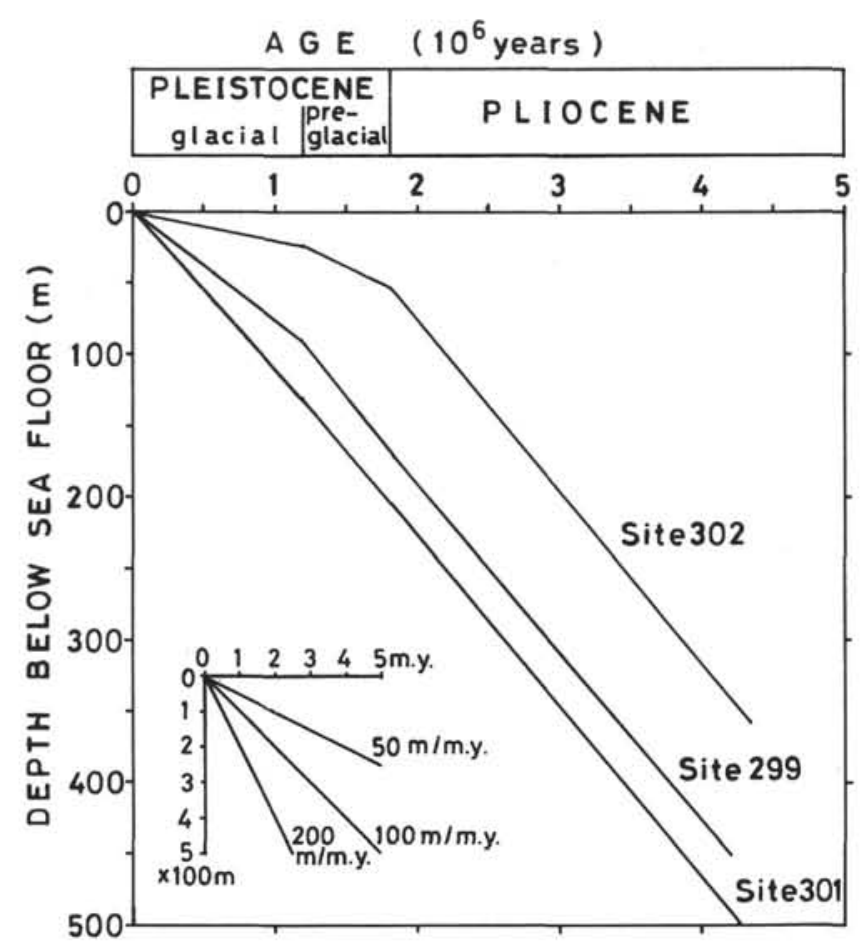

Figure 9. Sedimentation rates at Leg 31 drilling Sites 299 to 302 , based on diatom zonation and using the time scale of Berggren (1972).

Denticula seminae Simonsen and Kanaya, 1961: p. 503, pl. 1, fig. 2630; Sheshukova-Poretzkaya, 1967, p. 301, pl. 47, fig. 11a-B, pl. 48, fig. 6a- $\sigma$; Koizumi, 1972, p. 350, pl. 42, fig. 5a-6; Koizumi, 1973b, p. 832, pl. 5, fig. 1-13; Schrader, 1973a, p. 705, pl. 1, fig. 1-11, 36, 47; Schrader, 1973b, p. 420 , pl. 1, fig. 1-4; Koizumi and Kanaya, in press, pl. 1, fig. 1-6. (Plate 1, Figures 1-3)

Denticula seminae Simonsen and Kanaya var. fossilis Schrader, 1973: 1973b, p. 420, pl. 1, fig. 5, 6. Synonyms: As Denticula seminae Simonsen and Kanaya, Koizumi, 1972, p. 350, pl. 42, fig. 5a-b; Koizumi, 1973b, p. 832 , pl. 5, fig. 7-13. As Denticula seminae Simonsen and Kanaya forma fossilis Koizumi, Schrader, 1973a, p. 705 , pl. 5, fig. 30, 37, 38. (Plate 1, Figures 4-12)

Goniothecium tenue Brun, 1894: p. 77, pl. 5, fig. 5, 6; SheshukovaPoretzkaya, 1967, p. 232 , pl. 39 , fig. $6 \mathrm{a}-\sigma$, pl. 40 , fig. 5a- $\sigma$; Koizumi, 1973b, p. 833, pl. 7, fig. 7-9.

Hemiaulus polymorphus Grun., 1884: Hustedt, 1962a, p. 880, fig. 525, 526; Hanna, 1932, p. 193, pl. 11, fig. 7.

Hemidiscus cuneiformis Wall., 1860: Hustedt, 1962a, p. 904, fig. 542; Hanna and Brigger, 1966, p. 300, fig. 33; Wornardt, 1967, p. 36, fig. 51; Koizumi, 1968, p. 215, pl. 34, fig. 17, 18; Hanna, 1970, p. 189, fig. 35; Kanaya, 1971, p. 556, pl. 40.3, fig. 5, 6; Schrader, 1973a, p. 706, pl. 24, fig. 14. (Plate 4, Figure 2)

Hemidiscus simplicissimus Hanna and Grant, 1926: p. 147, pl. 16, fig. 13; Schrader, 1973a, p. 706, pl. 24, fig. 12, 13. (Plate 4, Figure 1)

Hemidiscus weissflogi (Grun.) Hust., Hustedt, 1955; p. 11, pl. 1, fig. 6, 7; Koizumi, 1972 , p. 351 , pl. 43 , fig. 14.

Nitzschia cylindrius (Grun.) Hasle, 1972: p. 115. Synonyms: As Fragilariopsis cylindrus (Grun.) Helmck and Krieger, 1954: Hustedt, 1958, p. 162, fig. 145, 146; Koizumi, 1972, p. 350, pl. 42, fig. 8, 9; Koizumi, 1973b, p. 832, pl. 7, fig. 1, 2. (Plate 1, Figure 49)

Nitzschia extincta Koz. and Sheshuk., in Sheshukova-Poretzkaya, 1967: p. 303, pl. 47, fig. 12; Koizumi, 1972, p. 351, pl. 42, fig. 10a$11 \mathrm{~b}$; Koizumi, 1973c, p. 134, pl. 20, fig. 16, 17.

Nitzschia fossilis (Fuengelli) Kanaya, in Kanaya and Koizumi,1970: p. 59; Koizumi, 1972, p. 352, pl. 42, fig. 14a-15c; Kobayashi et al., 1971, p. 1059, fig. 5, 7; Schrader, 1973a, p. 707, pl. 4, fig. 9-11, 24, 25; Koizumi and Kanaya, in press, pl. 1, fig. 11-14. (Plate 1, Figure 46)
Nitzschia marina Grun., in Cleve and Grunow, 1880: p. 70; Van Heurck, 1880, pl. 57, fig. 26, 27; Kolbe, 1954, p. 40, pl. 3, fig. 38-40.

Nitzschia reinholdii Kanaya, in Kanaya and Koizumi, 1970: p. 58; Koizumi, 1972, p. 351, pl. 42, fig. 16a-c; Schrader, 1973a, p. 708, pl. 4, fig. 1-9; Koizumi and Kanaya, in press, pl. 1, fig. 15-18. (Plate 1, Figures 47,48 )

Nitzschia sicula (Cast.) Hust., Hustedt, 1958: p. 180, fig. 128-132; Hasle, 1960 , p. 26 , fig. 16, pl. 7, fig. $64,65$.

Planktoniella sol (Wall.) Schütt, 1893: Hustedt, 1962a, p. 465, fig. 295; Hasle, 1960, p. 11, pl. 3, fig. 19-20; Belyaeva, 1968, p. 111, pl. 5, fig. 1, 2; Gerloff, 1970, p. 203, pl. 1-14, fig. 1-51.

Porosira glacialis (Grun.) Jörg., 1905: Hustedt, 1962a, p. 315, fig. 153; Jousé, 1962, pl. 2, fig. 1, pl. 79, fig. 11; Koizumi, 1973b, p. 833, pl. 4, fig. 15-18. (Plate 4, Figure 29; Plate 5, Figures 1, 2)

Pseudoeunotia doliolus (Wall.) Grun., 1880: Hustedt, 1962b, p. 258, fig. 737; Kolbe, 1954, p. 43, pl. 3, fig. 41; Kobayashi et al., 1971, p. 1059, fig. 5, 6; Burckle, 1972, pl. 3, fig. 7; Schrader, 1973a, p. 708, pl. 4, fig. 1-8; Koizumi and Kanaya, in press, pl. 1, fig. 9, 10. (Plate 1, Figures 41-45)

Pseudopodosira elegans Sheshuk., Sheshukova-Poretzkaya, 1964: p. 75, pl. 2, fig. 4, 5; Sheshukova-Poretzkaya, 1967, p. 178, pl. 24, fig. 3, pl. 25, fig. 4; Koizumi, 1972, p. 352, pl. 43, fig. 3, 4; Koizumi, 1973b, p. 833, pl. 4, fig. 14. (Plate 3, Figure 17)

Rhizosolenia alata Brig., 1858: Hustedt, 1962a, p. 600, fig. 345; Schrader, 1973a, p. 709, pl. 10, fig. 12. (Plate 1, Figure 38)

Rhizosolenia bergonii Perag., 1892: Hustedt, 1962a, p. 575, fig. 327; Jousé et al., 1969, pl. 13, fig. 7; Muchina, 1969, pl. 2, fig. 5; Koizumi, 1972, p. 353, pl. 42, fig. 7; Burckle, 1972, pl. 3, fig. 4; Schrader, 1973a, p. 709, pl. 9, fig. 1-5, 10, 12, 22, 23, pl. 10, fig. 24, 29; Koizumi and Kanaya, in press, pl. 1, fig. 20, 21.

Rhizosolenia curvirostris Jousé, 1968, p. 19, pl. 3, fig. 1-3; Donahue, 1970, p. 135, pl. 1, fig. a; Koizumi, 1973b, p. 833, pl. 5, fig. 29-31; Schrader, 1973a, p. 709, pl. 24, fig. 5, 6, 8, 9; Koizumi and Kanaya, in press, pl. 1, fig. 19. (Plate 1, Figures 35-37)

Rhizosolenia hebetata (Bail.) Gran forma hiemalis Gran, 1904: Hustedt, 1962a, p. 590, fig. 337; Jousé, 1957, pl. 4, fig. 3; Hendey, 1964 , p. 150, pl. 3, fig. 6; Koizumi, 1973b, p. 833, pl. 5, fig. 34, 35. Schrader, 1973a, p. 709, pl. 9, fig. 11, 13-17, 19-21, 24, 25. (Plate 1, Figures $31,32,34$ )

Rhizosolenia styliformis Brig., 1858: Hustedt, 1962a, p. 584, fig. 333; Hendey, 1964, p. 150, pl. 2, fig. 1; Schrader, 1973a, p. 710, pl. 10, fig. 1, 18-20, pl. 9, fig. 9. Synonyms: As Rhizosolenia sp. b, Koizumi, 1968, p. 217, pl. 34, fig. 23. (Plate 1, Figure 33)

Rhizosolenia sp. a, in Koizumi, 1968: p. 217, pl. 34, fig. 22a, b; Koizumi, 1973b, p. 833, pl. 5, fig. 36. (Plate 1, Figure 39)

Rhizosolenia sp. e, in Koizumi, 1968: p. 217, pl. 34, fig. 26; Koizumi, 1973b, p. 833, pl. 5, fig. 39. (Plate 1, Figure 40)

Roperia tesselata (Roper.) Grun., in Van Heurck, 1880: Hustedt, 1962a, p. 523, fig. 297; Schrader, 1973a, p. 710, pl. 19, fig. 3, 4, 8, 9. (Plate 3, Figures 15, 16)

Rouxia californica Perag., in Tempère and Peragallo, 1910: p. 117; Hanna, 1930, p. 186, pl. 14, fig. 6, 7; Schrader, 1973a, p. 710, pl. 3, fig. 18-20, 22, 26. Synonyms: As Rouxia peragalli Brun and Herib., forma californica (Perag.) Sheshuk., Sheshukova-Poretzkaya, 1956, p. 73, fig. 9-16: Sheshukova-Poretzkaya, 1967, p. 295, pl. 43, fig. 19, pl. 47, fig. 5a- $\sigma$; Koizumi, 1973b, p. 833, pl. 7, fig. 11. (Plate 1, Figure 52)

Rouxia naviculoides Schrader, 1973: 1973a, p. 710, pl. 3, fig. 27-32.

Rouxia peragalli Brun and Herib., in Heribaud, 1893: Hanna, 1930, p. 180, pl. 14, fig. 1, 5; Sheshukova-Poretzkaya, 1967, p. 294, pl. 43, fig. 17; Koizumi, 1968, p. 217, pl. 35, fig. 1, 2; Koizumi, 1973b, p. 833, pl. 7, fig. 10.

Stephanogonia hanzawae Kanaya, 1959: p. 118, pl. 11, fig. 3-7; Koizumi, 1968, p. 217, pl. 35, fig. 3a, b, 4.

Stephanopyxis dimorpha Schrader, 1973: 1973a, p. 711, pl. 15, fig. 9-11, 19,20 , pl. 16, fig. 1-3, 8-11, pl. 24, fig. 10. Remarks: As all specimen is separate with upper and lower valves, only lower valve is including to this taxon. Lower valve slightly convex with indented central part, 3-6 mucous pores near the center of valve. Areolae hexagonal in tangential rows becoming gradually smaller toward the margin, $4-5$ in $10 \mu$. (Plate 4, Figures 3-6)

Stephanopyxis horridus Koizumi, 1972: p. 348, pl. 42, fig. 1a-2b; Koizumi, 1973b, p. 833, pl. 6, fig. 1-4. (Plate 4, Figures 3, 4)

Stephanopyxis inermis Jousé, 1961: p. 60, pl. 1, fig. 2, pl. 3, fig. 1, 2; Sheshukova-Poretzkaya, 1967, p. 135, pl. 11, fig. 5a- $\sigma$, pl. 12, fig. 8; Koizumi, 1973b, p. 833, pl. 6, fig. 5-10. 
Stephanopyxis turris (Grev. and Arn.) Ralfs, in Pritchard, 1861: Hustedt, 1962a, p. 304, fig. 140; Cupp, 1943, p. 40, fig. 9; Kanaya, 1959 , p. 69, pl. 2, fig. 5-7; Koizumi, 1973b, p. 833, pl. 6, fig. 13-16.

Synedra jouseana Sheshuk., Sheshukova-Poretzkaya, 1962: p. 208, fig. 4; Sheshukova-Poretzkaya, 1967, p. 245, pl. 42, fig. 4a- $\sigma$, fig. 12a- $\sigma$; Kanaya, 1971, p. 556, pl. 40.5, fig. 15; Koizumi, 1973b, p. 833, pl. 6, fig. 17; Schrader, 1973a, p. 710, pl. 23, fig. 21-23, 25, 38.

Thalassionema nitzschioides Grun., 1881: Hustedt, 1962b, p. 244, fig. 723; Cupp, 1943, p. 182, fig. 133; Hanna, 1970, p. 194, fig. 37; Schrader, $1973 \mathrm{a}$, p. 712 , pl. 23 , fig. $2,6,8-10,26,29,34,12,13$; Koizumi, 1973c, p. 134, pl. 20, fig. 24, 25. (Plate 1, Figures 50, 51)

Thalassionema nitzschioides Grun. vars. Remarks: Following three varieties are presented: Thalassionema nitzschioides Grun. var. inflata Heiden and Kolbe, 1928: p. 564, pl. 35, fig. 116, Thalassionema nitzschioides Grun. var. incurvata Heiden and Kolbe, 1928: p. 564, pl. 35, fig. 117, Thalassionema nitzschioides Grun. var. parva Heiden and Kolbe, 1928: p. 564, pl. 35, fig. 118.

Thalassiosira antiqua (Grun.) Cl., Cleve-Euler, 1941: p. 173, fig. 4, 5, 74-84; Cleve-Euler, 1951, p. 72, fig. 119a; Sheshukova-Poretzkaya, 1967 , p. 143, pl. 14, fig. 3a, 6; Koizumi, 1968, p. 218, pl. 35, fig. 11; Koizumi, 1973b, p. 834, pl. 7, fig. 12; Schrader, 1973a, p. 712, pl. 11 , fig. 25, pl. 25, fig. 19; Koizumi, 1973c, p. 134, pl:20, fig. 12, 13. (Plate 4, Figure 9)

Thalassiosira convexa Much., Muchina, 1965: p. 22, pl. 11, fig. 1, 2; Kobayashi et al., 1971, p. 1059, fig. 5.3a-5.3b; Koizumi, 1972, p. 353, pl. 43, fig. 15a-16b; Burckle, 1972, pl. 2, fig. 22, 23; Koizumi, 1973b, p. 834, pl. 7, fig. 13-15; Schrader, 1973a, p. 712, pl. 11, fig. 37, 38. (Plate 4, Figures 15-20)

Thalassiosira decipiens (Grun.) Joerg., 1905: Hustedt, 1962a, p. 322, fig. 158; Cupp, 1943, p. 48, fig. 10; Sheshukova-Poretzkaya, 1964, p. 74 , pl. I, fig. 2 ; Koizumi, 1973 b, p. 834 , pl. 7, fig. 16-18; Schrader, 1973a, p. 712 , pl. 11, fig. 8, 9, 34, 35, pl. 16, fig. 12; Koizumi, 1973c, p. 134, pl. 20, fig. 6. (Plate 4, Figures 10-14)

Thalassiosira gravida Cl., Cleve, 1896: Hustedt, 1962a, p. 325, fig. 161; Cupp, 1943, p. 48, fig. 11; Hasle, 1968, p. 196, fig. 3, 4; Koizumi, 1972 , p. 353 , pl. 43 , fig. 1la-b; Koizumi, 1973b, p. 834, pl. 7, fig. 19-21; Schrader, 1973a, p. 712, pl. 14, fig. 3-8; Koizumi and Kanaya, in press, pl. 1, fig. 33,34 .

Thalassiosira gravida $\mathrm{Cl}$. forma fossilis Jousé, 1961: p. 63, pl. 1, fig. 9; Sheshukova-Poretzkaya, 1967, p. 147, pl. 15, fig. la-B; Koizumi, 1972, p. 353, pl. 43, fig. 10; Koizumi, 1973b, p. 834, pl. 7, fig. 22-24; Koizumi and Kanaya, in press, pl. 1, fig. 30-32. (Plate 5, Figures 712)

Thalassiosira hyalina (Grun.) Grun., 1897: Hustedt, 1962a, p. 323, fig. 159; Jousé, 1962, pl. 2, fig. 4; Jousé et al., 1969, pl. 4, fig. 1; Koizumi, 1972, p. 353, pl. 43, fig. 7; Koizumi, 1973b, p. 834, pl. 8, fig. 1, 2. (Plate 4, Figure 23)

Thalassiosira kryophila (Grun.) Joerg., 1905: Hustedt, 1962a, p. 324, fig. 160; Jousé, 1957, pl. 3, fig. 6; Jousé, 1962, pl. 2, fig. 5; Sheshukova-Poretzkaya, 1967, p. 146, pl. 14, fig. 6; Koizumi, 1968, p. 218 , pl. 35 , fig. 14,15 ; Koizumi, 1972, p. 354 , pl. 43, fig. 9 ; Koizumi, 1973b, p. 834, pl. 8, fig. 3. (Plate 4, Figures 25, 26)

Thalassiosira lineata Jousé, 1968: p. 13, pl. 1, fig. 1, 2; Koizumi, 1973b, p. 834 , pl. 7 , fig. 28,29 ; Koizumi, 1973 c, p. 134 , pl. 20 , fig. 7,8 . (Plate 5, Figure 22)

Thalassiosira manifesta Sheshuk., Sheshukova-Poretzkaya, 1964: p. 72, pl. 1, fig. 6, 7; Sheshukova-Poretzkaya, 1967, p. 147, pl. 14, fig. 9a, b; Koizumi, 1968, p. 219, pl. 35, fig. 16, 17. (Plate 5, Figure 6)

Thalassiosira nativa Sheshuk., Sheshukova-Poretzkaya, 1964: p. 75, pl. 1, figs. 4, 5; Sheshukova-Poretzkaya, 1967, p. 145, pl. 14, fig. 7a- $\sigma$; Koizumi, 1968, p. 219, pl. 35, fig. 19, 20; Burckle, 1972, pl. 3, fig. 6; Schrader, 1973a, p. 712, pl. 11, fig. 23, 24. (Plate 4, Figures 21, 22)

Thalassiosira nidulus (Temp. and Brun) Jousé, 1961: p. 63, pl. 3, fig. 4, 5; Sheshukova-Poretzkaya, 1967, p. 140, pl. 11, fig. 8a-c, pl. 14, fig. la-c; Koizumi, 1972, p. 354, pl. 43, fig. 6; Koizumi, 1973b, p. 834, pl. 7, fig. 25, 26; Schrader, 1973a, p. 712, pl. 11, fig. 1-7; Koizumi and Kanaya, in press, pl. 1, fig. 25. (Plate 4, Figures 27, 28)

Thalassiosira nordenskiöldi $\mathrm{Cl}$., 1875: Hustedt, 1962a, p. 321, fig. 157; Jousé, 1962, pl. 2, fig. 6, pl. 62, fig. 2, pl. 79, fig. 3-5; Hasle, 1968, p. I96, fig. 2, 4, 8; Koizumi, 1972, p. 354, pl. 43, fig. 8; Koizumi, 1973 b, p. 834, pl. 8, fig. 4; Schrader, 1973 a, p. 712 , pl. 14, fig. 9-12. (Plate 4, Figure 24)

Thalassiosira oestrupi (Ostf.) Proskina-Lavrenko, 1956: Hasle, 1960, p. 8, pl. 1, fig. 5-7; Jousé, 1968, p. 13, pl. 1, fig. 3-7; Koizumi, 1968, p. 219 , pl. 35 , fig. 24,25 ; Koizumi, 1973 b, p. 834 , pl. 7 , fig. 27 ;
Schrader, 1973a, pl. 11, fig. 16-22, 26-33, 36, 39-45. (Plate 5, Figures 3, 4)

Thalassiosira punctata Jousé, 1961: p. 64, pl. 1, fig. 7-9; SheshukovaPoretzkaya, 1967, p. 151, pl. 14, fig. 10, pl. 17, fig. la, b; Hanna, 1970 , p. 194 , fig. 5, 6; Koizumi, 1973b, p. 834, pl. 8, fig. 7-9; Schrader, 1973a, p. 712, pl. 17, fig. 20.

Thalassiosira undulosa (Mann) Sheshuk., Sheshukova-Poretzkaya, 1967: p. 148, pl. 16, fig. la-B; Koizumi, 1973b, p. 834, pl. 8, fig. 5, 6. (Plate 5, Figure 5)

Thalassiosira usatschevii Jousé, 1961: p. 64, pl. 3, fig. 6; SheshukovaPoretzkaya, 1967, p. 150, pl. 15, fig. 3a- $\sigma$; Koizumi, 1973b, p. 834, pl. 8, fig. 13-15. (Plate 5, Figures 18-21)

Thalassiosira zabelinae Jousé, 1961: p. 66, pl. 2, fig. 1-7; SheshukovaPoretzkaya, 1967, p. 149, pl. 16, fig. 2a- $\sigma$; Koizumi, 1968, p. 219 , pl. 35 , fig. 27 a-28b; Koizumi, 1972 , p. 354 , pl. 43 , fig. 17 a, b; Koizumi, 1973b, p. 834, pl. 8, fig. 10-12; Schrader, 1973a, p. 712, pl. 14, fig. 1, 2; Koizumi and Kanaya, in press, pl. i, fig. 27-29. (Plate 5, Figures 13-17)

Thalassiothrix longissima $\mathrm{Cl}$. and Grun., 1880: Hustedt, 1962b, p. 247, fig. 726; Cupp, 1943, p. 184, fig. 134; Jousé, 1962, pl. 3, fig. 12, pl. 62 , fig. 13; Sheshukova-Poretzkaya, 1967, p. 250, pl. 42, fig. 11; Hasle and de Mendiola, 1967, p. 114, fig. 20; Koizumi, 1973b, p. 834, pl. 8, fig. 16; Schrader, 1973a, p. 713, pl. 23, fig. 7, 17, 18.

\section{Marine Tychopelagic and Benthonic Diatoms}

Actinocyclus ehrenbergii Ralfs, in Pritchard, 1861: Hustedt, 1962a, p. 525, fig. 298-302; Schrader, 1973a, p. 701, pl. 19, fig. 1; Koizumi, 1973 c, p. 134 , pl. 20 , fig. $10,11$.

Actinoptychus adriaticus Grun. var. pumila Grun., 1863: Hustedt, 1962a, p. 481, fig. 269. Synonyms: As Actinoptychus vulgaris Schumann, Sheshukova-Poretzkaya, 1967, p. 185, pl. 28, fig. 2a- $\rho$. Remarks: Valves round, $45-75 \mu$ in diameter, differentiated into 1016 sectors. Valve sculpture dual, hyaline rays missing.

Actinoptychus undulatus (Bail.) Ralfs, in Pritchard, 1861: Hustedt, 1962 a, p. 475 , fig. 264; Cupp, 1943, p. 67 , fig. 29, pl. 5, fig. 1; Sheshukova-Poretzkaya, 1967, p. 184, pl. 27, fig. 1a- $\Delta$, pl. 28, fig. la-b; Koizumi, 1973c, p. 134, pl. 20, fig. 1a-3b; Schrader, 1973a, p. 702 , pl. 22 , fig. $4,5,12,15$.

Amphora coffeaeformis (Ag.) Kütz., 1844: Hustedt, 1930, p. 345, fig. 634.

Amphora costata W. Sm., 1853: Cleve-Euler, 1953, p. 99, fig. 690; Sheshukova-Poretzkaya, 1967, p. 297, pl. 47, fig. 6, pl. 48, fig. 1.

Amphora robusta Greg., 1957: Hendey, 1967, p. 262, pl. 38, fig. 7.

Arachnoidiscus ehrenbergi Bail., in Ehrenberg, 1849: Hustedt, 1962a, p. 471, fig. 262.

Campyloneis grevillei (W. Sm.) Grun., 1867: Hustedt, 1962b, p. 321, fig. 781; Hendey, 1967, p. 184, pl. 27, fig. 9-11.

Cocconeis antiqua Temp. and Brun, in Brun and Tempère, 1889: p. 32, pl. 8, fig. 5; Schmidt, 1894, pl. 191, fig. 49-52; Kanaya, 1959, p. 107, pl. 10, fig. 1, 2; Sheshukova-Poretzkaya, 1967, p. 269, pl. 45, fig. 1; Hanna, 1970, p. 183, fig. 48.

Cocconeis californica Grun., 1881: Hustedt, 1962b, p. 343, fig. 796; Sheshukova-Poretzkaya, 1967 , p. 269 , pl. 45 , fig. 1.

Cocconeis costata Greg., 1855: Hustedt, 1962b, p. 332, fig. 785; Miller, 1964 , p. 48, pl. 5, fig. 2; Sheshukova-Poretzkaya, 1967, p. 262, pl. 44, figs. 4a-B.

Cocconeis decipiens Cl., 1873: Hustedt, 1962b, p. 353, fig. 808.

Cocconeis dirupta Greg., 1857: Hustedt, 1962b, p. 354 fig. 809a-c.

Cocconeis fluminensis (Grun.) Perag., 1897: Hustedt, 1962b, p. 341, fig. 794.

Cocconeis maxima (Grun.) Perag., 1897: Hustedt, 1962b, p. 335, fig. 789.

Cocconeis notata Petit, 1877: Hustedt, 1937, p. 352, fig. 806.

Cocconeis pellucida Grun., in Rabehhorst, 1862: Hustedt, 1962b, p. 357 , fig. 812 .

Cocconeis pseudomarginata Greg., 1857: Hustedt, 1962b, p. 359, fig. 813; Hendey, 1964, p. 179, pl. 28, fig. 20.

Cocconeis quarnerensis Grun., 1874: Hustedt, 1962b, p. 360, fig. 814; Hendey, 1964, p. 184, pl. 28, fig. 13.

Cocconeis scutellum Ehr., 1938: Hustedt, 1962b, p. 337, fig. 790; Miller, 1964, p. 48, pl. 5, fig. 4, 5; Hendey, 1964, p. 180, pl. 27, fig. 8; Sheshukova-Poretzkaya, 1967 , p. 264 , pl. 44 , fig. 7 .

Cocconeis vitrea Brun, 1891: p. 19, pl. 18, fig. 2; Schmidt, 1894, pl. 194, fig. 11 (not named); Kanaya, 1959, p. 110, pl. 10, fig. 6; 
Sheshukova-Poretzkaya, 1967, p. 271, pl. 45, fig. 3a- $\sigma$; Wornardt, 1967 , p. 81 , fig. 183-184.

Coscinodiscus nitidus Greg., 1857: Hustedt, 1962, p. 414, fig. 221; Hendey, 1964, p. 76, pl. 23, fig. 12; Wornardt, 1967, p. 27, fig. 30, 31 .

Cyclotella striata (Kütz.) Grun., 1880: Hustedt, 1962a, p. 344, fig. 176.

Cymatosira debyi Temp. and Brun, in Brun and Tempère, 1889: p. 36, pl. 7, fig. 18a, b; Sheshukova-Poretzkaya, 1967, p. 237, pl. 40, fig. 7 , pl. 41 , fig. 6 .

Diploneis bombus Ehr., 1844: Hustedt, 1962b, p. 704, fig. 1086.

Diploneis campylodiscus (Grun.) Cl., 1894: Hustedt, 1962b, p. 600, fig. 1017.

Diploneis coffaeiformis (A. Schmidt) Cl., 1894: Hustedt, 1962b, p. 611, fig. 1025.

Diploneis constricta (Grun.) Cl., 1894: Hustedt, 1962b, p. 594, fig. 1012.

Diploneis crabro Ehr., 1854: Hustedt, 1962b, p. 616, fig. 1028; Hendey, 1964 , p. 225 , pl. 32, fig. 1, 3 .

Diploneis fusca (Greg.) Cl., 1894: Hustedt, 1962b, p. 654, fig. 1053; Hendey, 1964, p. 255 , pl. 32 , fig. 4.

Diploneis incurvata (Greg.) Cl., 1894: Hustedt, 1962b, p. 593, fig. 1012 b-d.

Diploneis interrupta (Kütz.) Cl., 1894: Hustedt, 1962b, p. 602, fig. 1019a; Patrick and Reimer, 1966, p. 416, pl. 36, fig. 12; Sheshukova-Poretzkaya, 1967 , p. 277 , pl. 46 , fig. 1.

Diploneis papula (A. Schmidt) Cl., 1894: Hustedt, 1962b, p. 679, fig. 1071.

Diploneis smithi (Bréb.) Cl., 1894: Hustedt, 1962b, p. 647, fig. 1051; Lohman, 1938, p. 84, pl. 23, fig. 10; Lohman, 1941, p. 84, pl. 17, fig. 18; Hendey, 1964, p. 225, pl. 32, fig. 10; Patrick and Reimer, 1966, p. 410, pl. 38, fig. 2.

Diploneis weissflogi (A. Schmidt) Cl., 1894: Hustedt, 1962b, p. 703, fig. 1085

Grammatophora spp. Remarks: No attempts have been made to identify all species of Grammatophora found at the various sites. The genus Grammatophora is characteristic of marine littoral biofacies. Among others the following species could be identified: G. arcuata Ehr., 1854, Hustedt, 1962b, p. 42, fig. 567; G. angulosa Ehr., 1839, Hustedt, 1962b, p. 39, fig. 564; G. arctica Cl., 1867, Hustedt, p. 38, fig. 563; G. marina (Lyng.) Kütz., 1844, Hustedt, p. 43, fig. 569.

Hyalodiscus scoticus (Kütz.) Grun., 1879: Hustedt, 1962b, p. 293, fig. 133.

Melosira albicans Sheshuk., Sheshukova-Poretzkaya, 1964: p. 69, fig. 1, 2, pl. 1, fig. 3; Sheshukova-Poretzkaya, 1967, p. 124, pl. 10, fig. 2a- $\sigma$, pl. 11, fig. 1a- $\sigma$; Koizumi, 1972, p. 351, pl. 43, fig. 1, 2.

Melosira sulcata (Ehr.) Kütz., 1844: Hustedt, 1962a, p. 276, fig. 119; Cupp, 1946, p. 40, fig. 2; Kanaya, 1959, p. 64, pl. 1, fig. 4-7; Miller, 1964 , p. 44, pl. 1, fig. 10-16; Mertz, 1966, p. 14, pl. 1, fig. 2; Sheshukova-Poretzkaya, 1967, p. 126, pl. 10, fig. 5, pl. 11, fig. 4a- $\sigma$; Hanna, 1970, p. 190, fig. 50, 51, 53.

Navicula directa (W. Smith) Ralfs, in Pritchard, 1861: Schmidt, 1874, pl. 47, fig. 1-3; Hendey, 1964, p. 202.

Navicula florinae Miller, 1950: Hendey, 1967, p. 213, pl. 33, fig. 6, 7.

Navicula forcipata Grev., 1859: Hustedt, 1971, p. 531, fig. 1568; Hendey, 1964, p. 211 , pl. 33, fig. 8, 9 .

Navicula hennedyi W. Smith, 1856: Hustedt, 1971, p. 453, fig. 15161523 ; Hendey, 1964 , p. 212 , pl. 33, fig. 14; Wornardt, 1967, p. 81 , fig. 185-188.

Navicula jamalinensis $\mathrm{Cl}$., var. simisevultus (Brun) $\mathrm{Cl}$, 1895: Sheshukova-Poretzkaya, 1967 , p. 283 , pl. 45 , fig. 5 .

Navicula lyra Ehr., 1841: Hustedt, 1971, p. 500, fig. 1548-1555; Hendey, 1964, p. 209, pl. 33, fig. 2; Wornardt, 1967, p. 82, fig. 189, $190,192$.

Nitzschia granulata Grun., 1862: Lohman, 1938, pl. 22, fig. 10; Miller, 1964 , p. 50 , pl. 6 , fig. 9 .

Nitzschia panduriformis Greg., 1857: Schmidt, pl. 331, fig. 19-21; Hendey, 1964, p. 279.

Nitzschia plana W. Smith, 1853: Hendey, 1967, p. 278, pl. 39, fig. 7

Nitzschia punctata (W. Smith) Grun., in Cleve and Grun., 1880: Hendey, 1967 , p. 278 , pl. 39, fig. 11.

Plagiogramma staurophorum (Greg.) Heib., 1863: Hustedt, 1962b, p. 110 , fig. 635 ; Hendey, 1964, p. 166, pl. 36, fig. 1.

Pleurosigma angulatum (Quekett) W. Smith, 1853: Hendey, 1967, p. 245 , pl. 35 , fig. $1-3$, pl. 41 , fig. 6 .

Rabdonema arcuatum (Lynb.) Kütz., 1844: Hustedt, 1962b, p. 20, fig. 549a, b, 549f, g; Hendey, 1964, p. 172, pl. 35, fig. 10-12.
Rhaphoneis amphiceros Ehr., 1844: Hustedt, 1962a, p. 174, fig. 680; Hendey, 1964, p. 154, pl. 26, fig. 1-4; Hanna, 1970, p. 192, fig. 29, 55, 56; Schrader, 1973a, p. 708, pl. 25, fig. 2, 3.

Rhaphoneis angustata Pant., Pantocsek, 1886: p. 33, pl. 11, fig. 97, pl. 30, fig. 313; Lohman, 1948, p. 180, pl. 11, fig. 11; SheshukovaPoretzkaya, 1967, p. 241, pl. 41, fig. 8a- $\sigma$, pl. 43, fig. 2; Koizumi, 1973 c, p. 134, pl. 20, fig. 21, 22.

Rhaphoneis margaritalimbata Mertz, 1966: p. 27, pl. 6, fig. 1-3; Koizumi, 1973c, p. 134, pl. 20, fig. 18.

Rhaphoneis surirella (Ehr.) Grun., 1880: Hustedt, 1962b, p. 173, fig. 679a-c; Lohman, 1941, p. 82, pl. 17, fig. 6; Hendey, 1964, p. 155, pl. 26, fig. 11-13; Schrader, 1973a, p. 709, pl. 25, fig. 4, 6; Koizumi, 1973 c, p. 134 , pl. 20 , fig. $19,20$.

Rhaphoneis tatsunokuchiensis Koizumi, 1972: p. 349, pl. 42, fig. 3, 4; Koizumi, 1973c, p. 134, pl. 20, fig. 14, 15.

Surirella ovata Kütz., 1844: Hendey, 1964, p. 287, pl. 40, fig. 7-9.

Trachyneis aspera (Ehr.) Cl., 1894: Hendey, 1964, p. 236, pl. 29, fig. 13.

Triceratium alternans Bail., 1851: Hustedt, 1962a, p. 825, fig. 488. Synonyms: As Biddulphia alternans (Bail.) Van Heurck, Hendey, 1964 , p. 102 , pl. 25 , fig. 5.

Triceratium condecorum Brig., 1853: Hanna, 1932, p. 221, pl. 17, fig. 1, 3; Sheshukova-Poretzkaya, 1959, p. 210, pl. 34, fig. 3a-c; Koizumi, 1968, p. 219. Synonyms: As Triceratium sp. 1, Schrader, 1973a, p. 713 , pl. 12 , fig. 12,16 .

\section{Fresh-Water Diatoms}

Achnanthes lanceolata (Bréb.) Grun., 1880: Hustedt, 1962b, p. 408, fig. 863; Patrick and Reimer, 1966, p. 269, pl. 18, fig. 1-10.

Amphora holsatica Hust., Hustedt, 1930: p. 345, fig. 633.

Amphora ovalis (Kütz.), 1844: Hustedt, 1930, p. 342, fig. 628.

Ceratoneis arcus (Ehr.) Kütz., 1844: Hustedt, 1930, p. 134, fig. 122; Hustedt, 1962b, p. 179, fig. 684a, b. Synonyms: As Hannaea arcus (Ehr.) Patr., Patrick and Reimer, 1966, p. 132, pl. 4, fig. 20.

Cocconeis diminuta Pant., 1902: Hustedt, 1962b, p. 346, fig. 800.

Cocconeis disculus (Schumann) Cl., 1895: Hustedt, 1962b, p. 345, fig. 799; Hendey, 1964, p. 178, pl. 28, fig. 19; Patrick and Reimer, 1966, p. 239 , pl. 15, fig. $1,2$.

Cocconeis ovalis (Hilse) Cl., 1891: Hustedt, 1930, p. 249, fig. 390; Hustedt, 1962b, p. 671, fig. 1065.

Cocconeis placentula Ehr. var. euglypta (Ehr.) Cl., 1895: Hustedt, 1930 , p. 261: Hustedt, 1962b, p. 349, fig. 802c; Patrick and Reimer, 1966, p. 241 , pl. 15 , fig. 8 .

Cyclotella chaetoceras Lemmerm., 1900: Hustedt, 1930, p. 100, fig. 74; Hustedt, 1962a, p. 344, fig. 175.

Cyclotella comta (Ehr.) Kutz., 1849: Hustedt, 1930, p. 103, fig. 69; Hustedt, 1962a, p. 354, fig. 183.

Cyclotella kuetzingiana Thwai., 1848: Hustedt, 1962a, p. 338, fig. 171.

Cyclotella operculata (Ag.) Kutz., 1833: Hustedt, 1930, p. 102, fig. 66: Hustedt, 1962a, p. 351, fig. 181a-d.

Cymbella affinis Kütz., 1844: Hustedt, 1930, p. 362, fig. 671

Cymbella parva (W. Smith) Cl., 1894: Hustedt, 1930, p. 363, fig. 675; Hanna, 1932, p. 379 , pl. 31, fig. 5 .

Cymbella simuata Greg., 1856:-Hustedt, 1930, p. 361, fig. 668a-b.

Cymbella tumidula Grun., 1875: Hustedt, 1930, p. 361, fig. 699.

Cymbella turgida (Greg.) Cl., 1894: Hustedt, 1930, p. 358, fig. 660.

Cymbella ventricosa Kütz., 1844: Hustedt, 1930, p. 359, fig. 661; Hanna, 1932, p. 379, pl. 32, fig. 3; Van Landingham, 1964, p. 47, pl. 23, fig. 1-39; Van Landingham, 1967, p. 43, pl. 11, fig. 7-11.

Diatoma vulgare Bory, 1828: Hustedt, 1930, p. 127, fig. 103; Hustedt, 1962 b, p. 96, fig. 628 .

Diploneis elliptica (Kütz.) Cl., 1894: Hustedt, 1930, p. 250, fig. 395; Hustedt, 1962b, p. 690 , fig. 1077 a.

Diploneis ovalis (Hilse) Cl., 1891: Hustedt, 1930, p. 249, fig. 390; Hustedt, 1962b, p. 671, fig. 1065a-e.

Epithemia argus Kütz., 1844: Hustedt, 1930, p. 383, fig. 727a.

Epithemia reichelti Fricke, 1904: Hustedt, 1930, p. 388, fig. 738.

Epithemia sorex Kutz., 1844: Hustedt, 1930, p. 388, fig. 736.

Epithemia zebra (Ehr.) Kutz., 1844: Hustedt, 1930, p. 384, fig. 729.

Eunotia spp. Remarks: No attempts have been made to identify all species of the genus Eunotia Ehr., 1837: Hustedt, 1962b, p. 264, fig. $740-779$, found at the various samples. The genus Eunotia is characteristic of fresh water biofacies.

Fragilaria construens (Ehr.) Grun., 1862: Hustedt, 1962b, p. 156, fig. 670a-c; Patrick and Reimer, 1966, p. 125, pl. 4, fig. 4; Van Landingham, 1967 , p. 23 , pl. 12 , fig. $1,11$. 
Gomphonema abbreviatum Ag., 1830: Hustedt, 1930, p. 379, fig. 722. Gomphonema angustatum (Kütz.) Rabh., 1864: Hustedt, 1930, p. 373, fig. 690 .

Gomphonema constrictum Ehr. var. capitata (Ehr.) Cl., 1894: Hustedt, 1930, p. 377 , fig. 715 .

Gomphonema lanceolatum Ehr., 1841: Hustedt, 1930, p. 376, fig. 700.

Gomphonema longiceps Ehr. var. subclavata Grun., in Cleve and Möller, 1881: Hustedt, 1930, p. 375, fig. 705.

Gomphonema olivaceum (Lyngb.) Kütz., 1844: Hustedt, 1930, p. 378, fig. 719 .

Gomphonema parvulum (Kütz.) Kütz., 1849: Hustedt, 1930, p. 372, fig. $713 \mathrm{a}$; Van Landingham, 1964, p. 44, pl. 45, fig. 6-8.

Gomphonema ventricosum Greg., 1856: Hustedt, 1930, p. 377, fig. 716.

Gyrosigma acuminatum (Kütz.) Rabh., 1853: Hustedt, 1930, p. 222, fig. 329 ; Patrick and Reimer, 1966, p. 314, pl. 23, fig. 1-3.

Hantzschia virgata (Rop.) Grun., in Cleve and Grunow, 1880: Hustedt, 1930 , p. 395 , fig. 752 ; Hendey, 1964, p. 285 , pl. 39 , fig. 1.

Licmophora spp. Remarks: No attempts have been made to treat the genus Licmophora Ag., 1827: Hustedt, 1962b, p. 52, fig. 579-619, systematically.

Melosira granulata (Ehr.) Ralfs, in Pritchard, 1861: Hustedt, 1930, p. 87, fig. 44; Hustedt, 1962a, p. 248, fig. 104.

Melosira islandica O. Möller, 1906: Hustedt, 1930, p. 88, fig. 48; Hustedt, 1962a, p. 252, fig. 106.

Opephora martyi Herib., Hustedt, 1930, p. 132, fig. 120; Hustedt, 1962b, p. 135, fig. 654; Patrick and Reimer, 1966, p. 115, pl. 3, fig. 3.

Pinnularia alpina W. Smith, 1853: Hustedt, 1930, p. 324, fig. 594, Patrick and Reimer, 1966, p. 618, pl. 58, fig. 11, 12.

Pinnularia borealis Ehr., 1841: Hustedt, 1930, p. 326, fig. 597; Patrick and Reimer, 1966, p. 618, pl. 58, fig. 13.

Pinnularia braunii (Grun.) Cl., 1895: Hustedt, 1930, p. 319, fig. 577; Patrick and Reimer, 1966, p. 594, pl. 55, fig. 3.

Pinnularia gibba Ehr., 1871: Hustedt, 1930, p. 327, fig. 600; Akutsu, 1964 , p. 278 , pl. 65 , fig. 1.

Pinnularia major (Kütz.) Cl., 1895: Hustedt, 1930, p. 331, fig. 614; Patrick and Reimer, 1966, p. 629, pl. 61, fig. 4.

Pinnularia subcapitata Greg., 1856: Hustedt, 1930, p. 317, fig. 571; Patrick and Reimer, 1966, p. 596, pl. 55, fig. 8-10.

Rhopalodia gibberula (Ehr.) O. Möller, 1897: Hustedt, 1930, p. 391, fig. 742.

Stephanodiscus astraea (Ehr.) Grun., 1880: Hustedt, 1930, p. 110, fig. 85; Hustedt, 1962a, p. 368, fig 193; Akutsu, 1964, p. 278, pl. 62, fig. 1, pl. 65, fig. 7.

Synedra ulna (Nitzsch) Ehr., 1838: Hustedt, 1930, p. 151, fig. 158, 159; Hustedt, 1962b, p. 195, fig. 691A-B; Patrick and Reimer, 1966, p. 148, pl. 7, fig. 1, 2.

Tabellaria fenestrata (Lyng.) Kütz., 1844: Hustedt, 1962b, p. 26, fig. 554-556; Patrick and Reimer, 1966, p. 103, pl. 1, fig. 1, 2.

Tetracyclus lacustris Ralfs, 1843: Hustedt, 1930, p. 121, fig, 95; Hustedt, 1962b, p. 12, fig. 545a-d; Patrick and Reimer, 1966, p. 102, pl. 1, fig. 9.

Tetracyclus rupestris (A. Braun) Grun., 1881: Hustedt, 1930, p. 121, fig. 98; Hustedt, 1962b, p. 15, fig. 547

\section{ACKNOWLEDGMENTS}

The writer thanks the Deep Sea Drilling Project and the sponsoring agency, the National Science Foundation, for having given him the opportunity of participating in Leg 31 aboard the D/V Glomar Challenger cruises, from Guam to Hakodate. The writer also thanks Dr. James C. Ingle, Jr., of the School of Earth Sciences, Stanford University, for critically reviewing the manuscript and continued help. Thanks are likewise due Mr. Kenichi Harada of the Department of Geology and Mineralogy, Kyoto University, for his assistance in photographic work; and Dr. Kojiro Nakaseko of the Institute of Geological Sciences, Osaka University, for his help and encouragement during this investigation. A special acknowledgment and debt of thanks is extended to Dr. James C. Ingle, Jr., and Dr. Daniel E. Karig, Co-chief scientists on Leg 31 , for their initial invitation to join Leg 31 .

\section{REFERENCES}

Akutsu, J., 1964. The geology and paleontology of Shiobara and its vicinity, Tochigi Prefecture: Sci. Rept. Tohoku Univ., 2nd ser. (Geol.), v. 35, p. 211.

Belyaeva, T. V., 1968. Diatom flora of the equatorial Pacific (along $140^{\circ} \mathrm{W}$ ): In Plankton in the Pacific Ocean, Izd. Akad. Nauk SSSR, Moscow, p. 103 (in Russian with English summary).

Berggren, W. A., in preparation (a). Biostratigraphy and biochronology of the Late Miocene (Messinian and Tortonian) of the Mediterranean.

, in preparation (b). The Pliocene time scale: Calibration of planktonic foraminifera and calcareous nannoplankton zones.

Blow, W. H., 1969. Late middle Eocene to Recent planktonic foraminiferal biostratigraphy: In Bronnomann, P. and Renz., H. H. (Eds.), First Intern. Conf. Plankt. Microfossils Proc., Leiden (Brill), v. 1, p. 199.

Bolli, H., 1957. Planktonic foraminifera from the OligoceneMiocene Cipero and Lengua formations of Trinidad, B.W.I. In Loeblich, H. R. Jr., et al. (Eds.), Studies in foraminifera: Bull. Nat. Museum, v. 215, p. 97.

Brun, J., 1891. Diatomées espèces nouvelles marines, fossiles ou pelagiques: Mèm. Soc. Phys. d'Hist. Nat. Genève, v. 31, p. 1 .

Brun, J. and Tempère, J., 1889. Diatomées fossiles du Japon. Espèces marines et nouvelles des calcaires argileux de Sendai and de Yedo: Mèm. Soc. Phys. d'Hist. Nat. Genève, v. 30 , p. 1.

Burckle, L. H., 1971. Correlation of Late Cenozoic marine sections in Japan and the equatorial Pacific: Proc. Paleontol. Soc. Japan Trans., v. 82, p. 117.

1972. Late Cenozoic planktonic diatom zones from the eastern equatorial Pacific: In Simonsen, R. (Ed.), Recent fossil marine diatoms Symp. 1st; Nova Hedwigia, v. 39 , p. 217.

Cleve-Euler, A., 1941. Alltertiäre Diatomeen und Silicoflagellaten im Junneren Schwedes: Paleontography, v. 92, p. 166. 1951-1955. Die Diatomeen von Schweden und Finnland: Kgl. Svenska Vet.-Akad. Handl., 4th ser. 5 vols.

Cleve, P. T. and Grunow, A., 1880. Beitrage sur kenntniss der Archtischen Diatomeen: Kgl. Svenska Vet.-Akad. Handl., v. 17, p. 1 .

Cupp, E. E., 1943. Marine planktonic diatoms of the West Coast of North America: Scripps Inst. Oceanogr. Bull., University of California, v. 5, p. 1.

Donahue, J. G., 1970. Pleistocene diatoms as climatic indicators in North Pacific sediments. In Hays, J. D. (Ed.), Geological investigations of the North Pacific: Geol. Soc. Am. INC., Mem 126, p. 121.

Fryxell, G. A. and Hasle, G. R., 1972. Thalassiosira eccentrica (Ehrenb.) Cleve, T. symmetrica sp. nov., and some related centric diatoms: J. Phycology, v. 8, p. 297.

Gerloff, J., 1970. Elektronenmikroskopische Untersuchungen an Diatomeenschalen VII: Der Bau der Schale von Planktoniella sol (Wallich) Schütt: In Gerloff, J. and Cholnoky, B. J. (Eds.), Diatomaceae II, Nova Hedwigia, v. 31, p. 203.

Grunow, A., 1884. Die Diatomeen von Franz Josefs-Land: Denkschr. Kgl. Akad. Wiss. Wien, Math. Nat. Wiss. Kl., v. 48 , p. 53.

Hanna, G. D., 1930. Review of the genus Rouxia: J. Paleontol., v. 4 , p. 179.

1932. The diatoms of Sharktooth Hill, Kern County, California: Proc. Calif. Acad. Sci., 4th ser., v. 20, p. 161. 1970. Fossil diatoms from the Pribilof Islands, Bering Sea, Alaska: Proc. Calif. Acad. Sci., 4th ser., v. 37, p. 167. 
Hanna, G. D. and Brigger, A. L., 1966. Fossil diatoms from southern Baja California: Proc. Calif. Acad. Sci., 4th ser., v. 30 , p. 285 .

Hanna, G. D. and Grant, W. M., 1926. Miocene marine diatoms from Maria Madre Island, Mexico (Expedition to the Revillagigedo Islands, Mexico, in 1925): Proc. Calif. Acad. Sci., 4th ser., v. 15, p. 115.

Hasle, G. R., 1960. Phytoplankton and cilate species from the tropical Pacific: Skrift. det Norske Videnskaps-Akad. Oslo, Matemat.-Naturv., v. 2, p. 1.

1968. The valve processes of the centric diatom genus Thalassiosira. Nytt Mag. Bot., v. 15, p. 193.

1972. Fragilariopsis Hustedt as a section of the genus Nitzschia Hassall: In Simonsen, R. (Ed.), Recent fossil marine diatoms Symp. Ist: Nova Hedwigia, v. 39, p. 111.

Hasle, G. R. and de Mendiola, B. R. E., 1967. The fine structure of some Thalassionema and Thalassiothrix species: Phycologia, v. 6, p. 107.

Hays, J.D., Saito, T., Opdyke, N. D., and Burckle, L. H., 1969. Pliocene-Pleistocene sediments of the equatorial Pacific: Their paleomagnetic, biostratigraphic, and climatic record: Geol. Soc. Am. Bull., v. 80, p. 1481.

Heiden, H. and Kolbe, R. W., 1928. Die Marinen Diatomeen der Deutschen Sudpolar-Expedition, 1901-1903: In Deutsche Südpolar-Expedition, 1901-1903: Berlin (Botanik), v. 8, p. 449.

Hendey, N. I., 1964. An introductory account of the smaller algae of British coastal water: Fish. Invest., ser. 4, pt. 5, Bacillariophyceae (Diatoms). London.

Hustedt, Fr., 1930. Bacillariophyta (Diatomeae), Heft 10: In Pascher, A. (Ed.), Die Süsswasser-Flora Mitteleuropas: Jena.

1955. Marine littoral diatoms of Beaufort, North Carolina: Bull. Duke Univ. Marine St., v. 6, p. 66.

1958. Diatomeen aus der Antarktis und dem Südatlantik: Deutsche Antarktische Exped. 1938-1939, v. 2, p. 103.

1962a. Die Kieselalgen Deutschland, Oesterreichs und der Schweiz mit Berücksichtigung der überrigen Länden Europas sowie der andrenzen den Meeresgebledt. In Rabenhorst, L. (Ed.), Kryptogamen-Flora von Deutschland, Oesterreichs und der Schweiz: Leipzig, v. 7. 1962b. Die Kieselalgen Deutschland, Oesterreichs und der Schweiz mit Berücksichtigung der überrigen Länden Europas sowie der andrenzen den Meeresgebiedt. In Rabenhorst, L. (Ed.), Kryptogamen-Flora von Deutschland, Oesterreichs und der Schweiz: Leipzig, v. 7. 1971. Die Kieselalgen Deutschland, Oesterreichs und der Schweiz mit Berucksichtigung der uberrigen Länden Europas sowie der andrenzen den Meersgebiedt. In Rabenhorst, L. (Ed.), Kryptogamen-Flora von Deutschland, Oesterreichs und der Schweiz, Leipzig, v. 7.

Jousé, A. P., 1957. Diatoms in the surface layer of the sediments in the Sea of Okhotsk: Tr. Inst. Okeanol., Akad. Nauk SSSR, 22, 164 (in Russian).

1961. Miocene and Pliocene marine diatoms from the Far East: Bot. Mater. Spor. Rast., Bot. Inst., Akad. Nauk SSSR, v. 16, p. 59 (in Russian).

1962. Stratigraphical and paleogeographical studies in the northwestern part of the Pacific Ocean: Akad. Nauk SSSR, Moscow (in Russian).

1968. New species of diatoms in bottom sediments of the Pacific and the Sea of Okhotsk: Nov. Systemat. Plant. non Vascular 1968, Akad. Nauk SSSR, v. 3, p. 12 (in Russian).
Jousé, A. P., Muchina, V. V., and Kozlova, O. G., 1969. Diatoms and silicoflagellates in the surface layer of sediments: In Bezrukov, P. L. (Ed.), the Pacific Ocean; microflora and microfauna in therecent sediments of Pacific OCean, Moscow, (Akad. Nauk SSSR), p. 7.

Kanaya, T., 1959. Miocene diatom assemblages from the Onnagawa Formation and their distribution in the correlative formations in northeast Japan: Sci. Rept. Tohoku Univ., 2nd ser. (Geol.), v. 30, p. 1.

1971. Some aspects of pre-Quaternary diatoms in the oceans: In Funnell, B. M. and Riedel, W. R. (Eds.), The micropaleontology of oceans: Cambridge (Cambridge University Press), p. 545.

Kanaya, T. and Koizumi, I., 1966. Interpretation of diatom thanatocoenoses from the North Pacific applied to a study of core V20-130 (Studies of a deep-sea core V20-130, part IV): Sci. Rept. Tohoku Univ., 2nd ser. (Geol.), v. 37, p. 89. 1970. The progress in the younger Cenozoic diatom stratigraphy in the northern circum-Pacific region: J. Marine Geol., v. 6, p. 47.

Kobayashi, K., Kitazawa, K., Kanaya, T., and Sakai, T., 1971. Magnetic and micropaleontological study of deep-sea sediments from the west-central equatorial Pacific: Deepsea Res., v. 18, p. 1045.

Koizumi, I., 1968. Tertiary diatom flora of Oga Peninsula, Akita Prefecture, northeast Japan: Sci. Rept. Tohoku Univ., 2nd ser. (Geol.), v. 40, p. 171.

1972. Marine diatom flora of the Pliocene Tatsunokuchi Formation in Fukushima Prefecture, northeast Japan: Paleont. Soc. Japan Trans. Proc., v. 86, p. 340. 1973a. Diatom ranges and diatom biostratigraphy in Japan: In Ikebe, N. (Ed.), Neogene biostratigraphy and radiometric time scale of Japan; Geol. Soc. Japan, Mem. 8, p. 35 .

1973b. The Late Cenozoic diatoms of Sites 183-193, Leg 19, Deep Sea Drilling Project: In Creager, J. S., Scholl, D. W., et al. (Eds.), Initial Report of Deep Sea Drilling Project, Volume 19: Washington (U.S. Government Printing Office), p. 805.

1973c. Marine diatom flora of the Pliocene Tatsunokuchi Formation in Miyagi Prefecture: Palaeont. Soc. Japan Trans. Proc., v. 79, p. 126.

Koizumi, I. and Kanaya, T., in press. Late Cenozoic marine diatom sequence from the Choshi district, Pacific coast, central Japan: In Takayanagi, Y. (Ed.), Progress in micropaleontology; selected papers in honor of Kiyoshi Asano: Am Mus. Nat. Hist.

Kolbe, R. W., 1954. Diatoms from equatorial Pacific cores: Rept. Swedish Deep-Sea Exped., v. 6, p. 1.

Lohman, K. E., 1938. Pliocene diatoms from the Kettleman Hills, California: U.S. Geol. Surv. Prof. Paper 189-C, p. 81. 1941. Diatomaceae, part 3: In Bradley, W. H., et al. (Eds.), Geology and biology of North Atlantic deep-sea cores, between Newfoundland and Ireland; U.S. Geol. Surv. Prof. Paper 196-B, 5-14, and 55-86.

Maiya, S., Saito, T. and Sato, T., in press. Late Cenozoic planktonic foraminiferal biostratigraphy of northwest Pacific sedimentary sequences: In Takayanagi, Y. (Ed.), Progress in micropaleontology; selected papers in honor of Kiyoshi Asano: Am. Mus. Nat. Hist.

Mann, A., 1907. Report on the diatoms of the "Albatross" voyage in the Pacific Ocean, 1888-1904: U.S. Nat. Herb., Contrib., v. 10, p. 221.

Mertz, D., 1966. Mikropaläontoogische und Sedimentologische Untersuchung der Pisco-Formation Sudperus: Paleontography, v. 118, p. 1. 
Miller, U., 1964. Diatom floras in the Quaternary of the Göta river valley, Western Sweden: Sveriges Geol. Undersokning., v. 44 , p. 1.

Muchina, V. V., 1965. New species of diatoms from the bottom sediments of the equatorial region of the Pacific: Nov. Systemat. Plant. non Vascular 1965, Akad. Nauk SSSR, v. 11 , p. 22 (in Russian).

, 1969. Biostratigraphy of sediments and questions of paleogeography of the tropical region of the Pacific and Indian Oceans: In Jousé, A. P. (Ed.), Micropaleontology and organogenous sedimentation in the oceans: Moscow (8th Congr. INQUA. Akad. Nauk SSSR), p. 52.

Opdyke, N. D., 1972. Paleomagnetism of deep-sea cores: Rev. Geoph. Space. Physics, v. 10, p. 213.

Pantocsek, J. 1886. Beiträge zur Kenntniss der Fossilen Bacillarien Ungarns: Berlin, part 1.

Patrick, R. and Reimer, C. W., 1966. The diatoms of the United States, exclusive of Alaska and Hawaii: Acad. Nat. Sci. Philadelphia, Monogr. 13, v. 1.

Rattray, J., 1890. A revision of the genus Actinocyclus Ehr.: J. Quekett Micros. club, 2nd ser., v. 4, p. 137.

Saito, T., 1963. Miocene planktonic foraminifera from Honshu, Japan: Sci. Rept. Tohoku Univ., 2nd ser. (Geol.), v. 35 , p. 124 .

1969. Late Cenozoic stage boundaries in deep-sea sediments: Geol. Soc. Am., Abstracts for 1969, part 7, p. 289.

Schmidt, A., 1874. Atlas der Diatomaceen-Kunde: Leipzig, Heft 1.

$9-12$.

1876. Atlas der Diatomaceen-Kunde: Leipzig, Heft 48-49.

Schrader, H. J., 1973a. Cenozoic diatoms from the northeast Pacific, Leg 18: In Kulm, L. D., von Huene, R., et al. (Eds.), Initial Reports of the Deep Sea Drilling Project, Volume 18: Washington.(U.S. Government Printing Office), p. 673.

1973b. Stratigraphic distribution of marine Denticula species in Neogene North Pacific sediments: Micropaleontology, v. 19, p. 417.
1974. Cenozoic marine planktonic diatom stratigraphy of tropical Indian Ocean: In Fisher, R. L., Bunce, E. T., et al. (Eds.), Initial Reports of the Deep Sea Drilling Project, Volume 24: Washington (U.S. Government Printing Office), p. 887.

Sheshukova-Poretzkaya, V. S., 1956. On the origin of fossil Rouxia Brun and Heribaud (Bacillariopyta): Bot. Matr. Bot. Inst. Akad. Nauk SSSR, v. 11, p. 64 (in Russian). 1962. New and rare diatoms from formations of Sakhalin: Leningrad Gos. Univ., Vest. no. 313, Biol. Inst. ser. Biol., Nauk Vup., v. 49, p. 203 (in Russian). , 1964. New and rare marine diatoms of the Neogene of Sakhalin and Kamtchatka: Nov. Systemat. Plant. non Vascular 1964. Akad. Nauk SSSR, v. 10, p. 69 (in Russian). 1967. Neogene marine diatoms of Sakhalin and Kamtschatica: Izd. Leningrad Univ. (in Russian).

Shinbo, K. and Maiya, S., 1969. Neogene Tertiary planktonic foraminiferal zonation in the Japanese oil producing provinces: Rept. Japanese Dele., 4th ECAFE Petraol. Sympo., p. 1.

Simonsen, R. and Kanaya, T., 1961. Note on the marine species of the diatom genus Denticula Kütz.: Int. Revue. Ges. Hydrobiol., v. 46, p. 498.

Tempère, J. and Peragallo, H., 1910. Diatomées du Monde Entier, 2nd Ed. 30 fasc., Arcachon, Grez-sur-Loing (S.-etM.), pt. 1 .

Van Heurck, H., 1880. Synopsis des diatomées de Belgique: Anvers, Atlas. Text.

Van Landingham, S. L., 1964. Miocene non-marine diatoms from the Yakima region in south central Washington: Nova Hed., v. 14. 1967. Paleoecology and microfloristics of Miocene diatomites from the Otis basin-Juntura region of Harney and Malheur counties, Oregon: Nova Hed., v. 26.

Wilcoxon, J. A. and Bramlette, M. N., 1967. Middle Tertiary calcareous nannoplankton of the Cipero section, Trinidad, W. I.: Tulane Stud. Geol., v. 5, p. 93.

Wornardt, W. W., Jr., 1967. Miocene and Pliocene marine diatoms from California: Calif. Acad. Sci., Occasional Papers, v. 63, p. 1. 


\section{PLATE 1}

Figure 1 Denticula seminae Simonsen and Kanaya. Slide 3005, $17 \mu$ in length, Sample 302-2-3, 23-24 cm, Rhizosolenia curvirostris Zone, middle Pleistocene. $\times 1500$.

Figures 2, 3 Denticula seminae Simonsen and Kanaya. Slide 3125, $18 \mu$ in length, Sample 301-3, $\mathrm{CC}$, Actinocyclus oculatus Zone, lower Pleistocene. $\times 1500$.

Figures 4, 5 Denticula seminae Simonsen and Kanaya var. fossilis Schrader. Slide $3171,19 \mu$ in length, Sample 301-11, CC, Denticula seminae var. fossilis Zone, upper Pliocene. $\times 1500$.

Figures 6, 7 Denticula seminae Simonsen and Kanaya var. fossilis Schrader. Slide 3015, 22 $\mu$ in length, Sample 302-2, CC, Actinocyclus oculatus Zone, lower Pleistocene. $\times 1500$.

Figures 8, 9 Denticula seminae Simonsen and Kanaya var. fossilis Schrader. Slide 3297, $28 \mu$ in length, Sample 299-10-5, 104-105 cm, Rhizosolenia curvirostris Zone, middle Pleistocene. $\times 1500$.

Figures 10, 11 Denticula seminae Simonsen and Kanaya var. fossilis Schrader. Slide 3017, $28 \mu$ in length, Sample 302-3-1, 121-122 cm, Actinocyclus oculatus Zone, lower Pleistocene. $\times 1500$.

Figure 12 Denticula seminae Simonsen and Kanaya var. fossilis Schrader. Slide $3035,22 \mu$ in length, Sample 302-5-1, 85-86 cm, Denticula seminae var. fossilis Zone, upper Pliocene. $\times 1500$.

Figure 13 Denticula kamtschatica Zabelina. Slide 3003, $12 \mu$ in length, Sample 302-2-1, 80-81 $\mathrm{cm}$, Rhizosolenia curvirostris Zone, middle Pleistocene. $\times 1500$.

Figure 14 Denticula kamtschatica Zabelina. Slide 3173, $16 \mu$ in length, Sample 301-12, CC, Denticula seminae var. fossilis Zone, upper Pliocene. $\times 1500$.

Figure 15 Denticula kamtschatica Zabelina. Slide 3003, $16 \mu$ in length, Sample 302-2-1, 80-81 $\mathrm{cm}$, Rhizosolenia curvirostris Zone, middle Pleistocene. $\times 1500$.

Figure 16 Denticula kamtschatica Zabelina. Slide 3003, $19 \mu$ in length, Sample 302-2-1, 80-81 $\mathrm{cm}$, Rhizosolenia curvirostris Zone, middle Pleistocene. $\times 1500$.

Figure 17 Denticula kamtschatica Zabelina. Slide 3045, 20 $\mu$ in length, Sample 302-5, CC, Denticula seminae var. fossilis-Denticula kamtschatica Zone, middle Pliocene. $\times 1500$.

Figure 18 Denticula kamtschatica Zabelina. Slide 3003, $23 \mu$ in length, Sample 302-2-1, 80-81 $\mathrm{cm}$, Rhizosolenia curvirostris Zone, middle Pleistocene. $\times 1500$.

Figure 19 Denticula kamtschatica Zabelina. Slide 3123, $25 \mu$ in length, Sample 301-3-1, 108-109 $\mathrm{cm}$, Actinocyclus oculatus Zone, lower Pleistocene. $\times 1500$.

Figure 20 Denticula kamtschatica Zabelina. Slide 3043, $26 \mu$ in length, Sample 302-5-5, 70-71 $\mathrm{cm}$, Denticula seminae var. fossilis-Denticula kamtschatica Zone, middle Pliocene. $\times 1500$.

Figures 21, 22 Denticula hyalina Schrader. Slide 3081, $11 \mu$ in length, Sample 302-11-1, 64-65 cm, Denticula seminae var. fossilis Zone, upper Pliocene. $\times 1500$.

Figures 23, 24 Denticula hyalina Schrader. Slide 3265, $19 \mu$ in length, Sample 299-5-3, 68-69 cm, Rhizosolenia curvirostris Zone, middle Pleistocene. $\times 1160$.

Figures 25, 26 Denticula hyalina Schrader. Slide 3081, $11 \mu$ in length, Sample 302-11-1, 122-123 cm, Denticula kamtschatica Zone, lower Pliocene. $\times 1500$.

Figure 27 Denticula dimorpha Schrader. Slide 3271, $13 \mu$ in length, Sample 299-6-3, 25-26 cm, Rhizosolenia curvirostris Zone, middle Pleistocene. $\times 1160$.

Figure 28 Denticula dimorpha Schrader. Slide 3367, 15 $\mu$ in length, Sample 299-25, CC, Denticula seminae var. fossilis Zone, upper Pliocene. $\times 1500$.

Figure 29 Rhizosolenia praebergonii Muchina. Slide 3337, broken specimen, Sample 299-18, $\mathrm{CC}$, Denticula seminae var. fossilis Zone, upper Pliocene. $\times 1000$.

Figure 30 Rhizosolenia praebergonii Muchina. Slide 3319, broken specimen, Sample 299-16-2, $100-101 \mathrm{~cm}$, Actinocyclus oculatus Zone, lower Pleistocene. $\times 1000$. 


\section{PLATE 1 (Continued)}

Figure 31 Rhizosolenia hebetata (Bail.) Gran. Slide 3121, broken specimen, Sample 301-2, CC, Rhizosolenia curvirostris Zone, middle Pleistocene. $\times 1000$.

Figure 32 Rhizosolenia hebetata (Bail.) Gran. Slide 3003, broken specimen, Sample 302-2-1, 80$81 \mathrm{~cm}$, Rhizosolenia curvirostris Zone, middle Pleistocene. $\times 1000$.

Figure 33 Rhizosolenia styliformis Brightw. Slide 3003, broken specimen, Sample 302-2-1, 80$81 \mathrm{~cm}$, Rhizosolenia curvirostris Zone, middle Pleistocene. $\times 1000$.

Figure 34 Rhizosolenia hebetata (Bail.) Gran. Slide 3001, broken specimen, Sample 302-1, CC, Rhizosolenia curvirostris Zone, middle Pleistocene. $\times 1000$.

Figure 35 Rhizosolenia curvirostris Jousé. Slide 3001, broken specimen, Sample 302-1, CC, Rhizosolenia curvirostris Zone, middle Pleistocene. $\times 700$.

Figure 36 Rhizosolenia curvirostris Jousé. Slide 3045, broken specimen, Sample 302-5, CC, Denticula seminae var. fossilis-Denticula kamtschatica Zone, middle Pliocene. $\times 1000$.

Figure 37 Rhizosolenia curvirostris Jousé. Slide 3005, broken specimen, Sample 302-2-3, 23-24 $\mathrm{cm}$, Rhizosolenia curvirostris Zone, middle Pleistocene. $\times 1000$.

Figure 38 Rhizosolenia alata Schrader. Slide 3337, broken specimen, Sample 299-18, CC, Denticula seminae var. fossilis Zone, upper Pliocene. $\times 1000$.

Figure 39 Rhizosolenia sp. a. Slide 3101, broken specimen, Sample 302-16-1, 98-99 cm, Denticula kamtschatica Zone, lower Pliocene. $\times 1000$.

Figure $40 \quad$ Rhizosolenia sp. e. Slide 3241, broken specimen, Sample 299-1-5, 80-81 cm, Denticula seminae Zone, upper Pleistocene. $\times 1000$.

Figure 41 Pseudoeunotia doliolus (Wall.) Grunow. Slide 3001, 73 $\mu$ in length, Sample 302-1, CC, Rhizosolenia curvirostris Zone, middle Pleistocene. $\times 1000$.

Figures 42, 43 Pseudoeunotia doliolus (Wall.) Grunow. Slide 3263, $37 \mu$ in length, Sample 299-4, CC, Rhizosolenia curvirostris Zone, middle Pleistocene. $\times 1000$.

Figures 44, 45 Pseudoeunotia doliolus (Wall.) Grunow. Slide 3271, 54 $\mu$ in length, Sample 299-6-3, $25-26 \mathrm{~cm}$, Rhizosolenia curvirostris Zone, middle Pleistocene. $\times 1000$.

Figure $46 \quad$ Nitzschia fossilis Kanaya. Slide 3309, 58 $\mu$ in length, Sample 299-13-3, 13-14 cm, Actinocyclus oculatus Zone, lower Pleistocene. $\times 1000$.

Figure $47 \quad$ Nitzschia reinholdii Kanaya. Slide 3041, 37 $\mu$ in length, Sample 302-5-4, 20-21 cm, Denticula seminae var. fossilis-Denticula kamtschatica Zone, middle Pliocene. $\times 1000$.

Figure $48 \quad$ Nitzschia reinholdii Kanaya. Slide 3317, broken specimen, Sample 299-15-3, 15-16 $\mathrm{cm}$, Actinocyclus oculatus Zone, lower Pleistocene. $\times 1000$.

Figure $49 \quad$ Nitzschia cyclidrius (Grunow) Hasle. Slide 3005, $49 \mu$ in length, Sample 302-2-3, 23$24 \mathrm{~cm}$, Rhizosolenia curvirostris Zone, middle Pleistocene. $\times 1000$.

Figure $50 \quad$ Thalassionema nitzschioides Grunow. Slide 3101, 33 $\mu$ in length, Sample 302-16-1, 98$99 \mathrm{~cm}$, Denticula kamtschatica Zone, lower Pliocene. $\times 1000$.

Figure 51 Thalassionema nitzschioides Grunow. Slide 3101, 60 $\mu$ in length, Sample 302-16-1, 98$99 \mathrm{~cm}$, Denticula kamtschatica Zone, lower Pliocene. $\times 1000$.

Figure 52 Rouxia californica Peragallo. Slide 3095, 82 $\mu$ in length, Sample 302-15, CC, Denticula kamtschatica Zone, lower Pliocene. $\times 1000$.

(See p. 810) 
PLATE 1
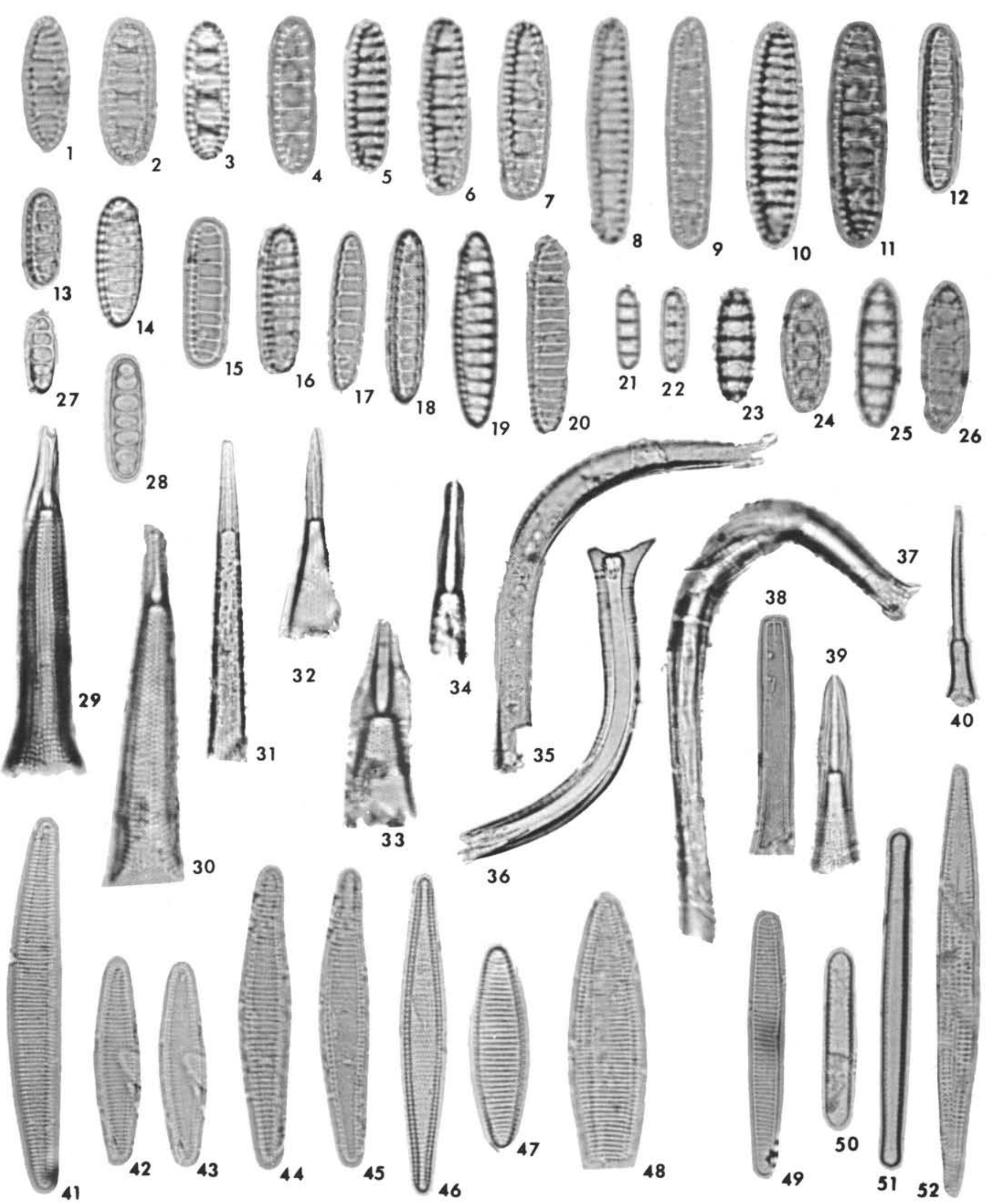

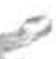


PLATE 2

Figures 1, 2 Actinocyclus divisus (Grun.) Hust. Slide 3289, 35 $\mu$ in diameter, Sample 299-9-5, 25-26 cm, Rhizosolenia curvirostris Zone, middle Pleistocene. $\times 1000$.

Figures 3, 4 Actinocyclus divisus (Grun.) Hust. Slide 3141, $45 \mu$ in diameter, Sample $301-5-3,32-33 \mathrm{~cm}, A c$ tinocyclus oculatus Zone, lower Pleistocene. $\times 1000$.

Figures 5,6 Bacterosira fragilis Gran. Slide $3015,18 \mu$ in diameter, Sample 302-2, CC, Rhizosolenia curvirostris Zone, middle Pleistocene. $\times 1000$.

Figures 7,8 Actinocyclus curvatulus Jan. Slide $3059,52 \mu$ in diameter, 302-8-1, 10-11 cm, Denticula seminae var. fossilis-Denticula kamtschatica Zone, middle Pliocene. $\times 1000$.

Figures 9,10 Actinocyclus curvatulus Jan. Slide $3001,53 \mu$ in diameter, Sample 302-1, CC, Rhizosolenia curvirostris Zone, middle Pleistocene. $\times 1000$.

Figure $11 \quad$ Actinocyclus ochotensis Jousé. Slide 3161, $27 \mu$ in diameter, Sample 301-8, CC, Denticula seminae var. fossilis Zone, upper Pliocene. $\times 1000$.

Figure 12 Actinocyclus ochotensis Jousé. Slide $3151,31 \mu$ in diameter, Sample 301-6, CC, Actinocyclus oculatus Zone (?), lower Pleistocene (?). $\times 1000$.

Figure 13 Actinocyclus ochotensis Jousé. Slide $3115,45 \mu$ in diameter, Sample 301-2-3, 35-36 cm, Rhizosolenia curvirostris Zone, middle Pleistocene. $\times 1000$.

Figures 14, 15 Actinocyclus oculatus Jousé. Slide $3125,24 \mu$ in diameter, Sample 301-3, CC, Actinocyclus oculatus Zone, lower Pleistocene. $\times 1000$.

Figure 16 Actinocyclus oculatus Jousé. Slide $3015,24 \mu$ in diameter, Sample 302-2, CC, Actinocyclus oculatus Zone, lower Pleistocene. $\times 1000$.

Figure 17 Actinocyclus oculatus Jousé. Slide $3015,23 \mu$ in diameter, Sample 302-2, CC, Actinocyclus oculatus Zone, lower Pleistocene. $\times 1000$.

Figures 18-19 Coscinodiscus excentricus Ehr. Slide 3147, $40 \mu$ in diameter, Sample 301-5-6, 141-142 cm, $A c$ tinocyclus oculatus Zone, lower Pleistocene. $\times 1000$.

Figure 20 Coscinodiscus excentricus Ehr. var. fasciculata Hust. Slide $312147 \mu$ in diameter, Sample 301-2, CC, Rhizosolenia curvirostris Zone, middle Pleistocene. $\times 1000$.

(See p. 812) 
PLATE 2
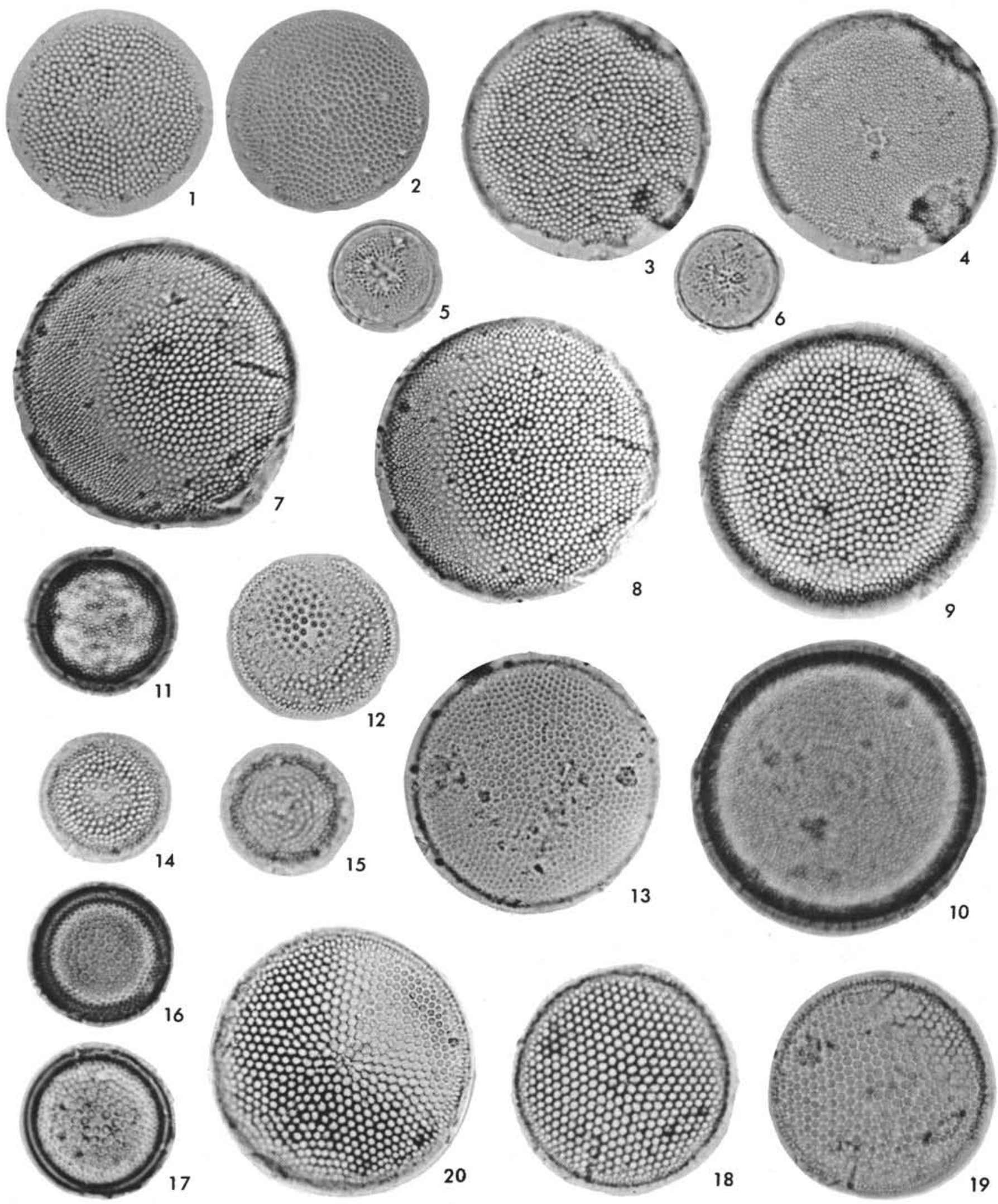


\section{PLATE 3}

Figures 1, 2 Coscinodiscus excentricus Ehr. var. jousei Kanaya. Slide 3003, $45 \mu$ in diameter, Sample 302-2-1, 80-81 $\mathrm{cm}$, Rhizosolenia curvirostris Zone, middle Pleistocene. $\times 1000$.

Figures 3, $4 \quad$ Coscinodiscus excentricus Ehr. var. jousei Kanaya. Slide $3025,53 \mu$ in diameter, Sample 302-3, CC, Actinocyclus oculatus Zone (?), lower Pleistocene (?). $\times 1000$.

Figure $5 \quad$ Coscinodiscus excentricus Ehr. var. leasareolatus Kanaya. Slide $3005,48 \mu$ in diameter, Sample 3022-3, 23-24 cm, Rhizosolenia curvirostris Zone, middle Pleistocene. $\times 1000$.

Figure 6 Coscinodiscus marginatus Ehr. Slide 3049, $45 \mu$ in diameter, Sample 302-7-1, 10-11 cm, Denticula seminae var. fossilis-Denticula kamtschatica Zone, middle Pliocene. $\times 1000$.

Figure 7 Coscinodiscus marginatus Ehr. forma fossilis Jousé. Slide 3065, $60 \mu$ in diameter, Sample 302-8$5,10-11 \mathrm{~cm}$, Denticula kamtschatica Zone, lower Pliocene. $\times 1000$.

Figure $8 \quad$ Coscinodiscus pustulatus Mann. Slide 3189, $29 \mu$ in diameter, Sample 301-16-1, 71-72 cm, Denticula seminae var. fossilis-Denticula kamtschatica Zone, middle Pliocene. $\times 1000$.

Figures 9, 10 Coscinodiscus pustulatus Mann. Slide 3215, 35 $\mu$ in diameter, Sample 301-19, CC, Denticula kamtschatica Zone, lower Pliocene. $\times 1000$.

Figure $11 \quad$ Coscinodiscus nodulifer Schmidt. Slide 3337, 37 $\mu$ in diameter, Sample 299-18, CC, Denticula seminae var. fossilis-Denticula kamtschatica Zone, middle Pliocene. $\times 1000$.

Figure 12 Coscinodiscus nodulifer Schmidt. Slide 3283, $29 \mu$ in diameter, Sample 299-8-3, 126-127 cm, Rhizosolenia curvirostris Zone, middle Pleistocene. $\times 1000$.

Figures 13, 14 Coscinodiscus radiatus Ehr. var. 1. Slide 3243, 79 $\mu$ in diameter, Sample 299-2, CC, Denticula seminae Zone, upper Pleistocene. $\times 700$ on Figure 13, $\times 1000$ on Figure 14 .

Figures 15, 16 Roperia tesselata (Roper) Grunow. Slide 3151, 55 $\mu$ in diameter, Sample 301-6, CC, Actinocyclus oculatus Zone (?), lower Pleistocene (?). $\times 1000$.

Figure $17 \quad$ Pseudopodosira elegans Sheshuk. Slide 3087, $12 \mu$ in diameter, Sample 302-12, CC, Denticula kamtschatica Zone, lower Pliocene. $\times 1000$.

(See p. 814) 
PLATE 3

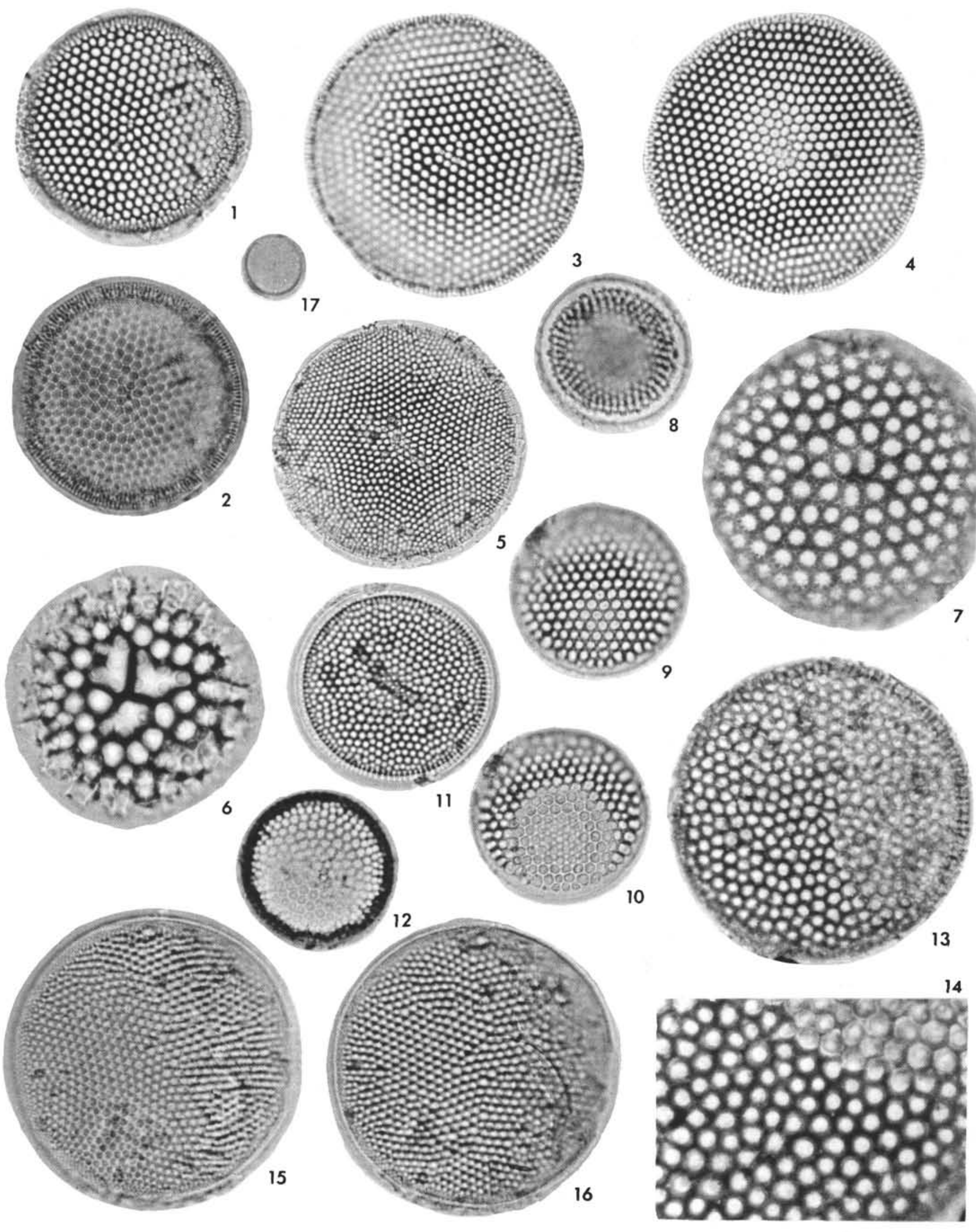




\section{PLATE 4}

Figure $1 \quad$ Hemidiscus simplicissimus Hanna and Grant. Slide 3319, $28 \mu$ in length, Sample 29916-2, 100-101 cm, Actinocyclus oculatus Zone, lower Pleistocene. $\times 1000$.

Figure 2 Hemidiscus cuneiformis Wall. Slide 3047, 49 $\mu$ in length, Sample 302-6, CC, Denticula seminae var. fossilis-Denticula kamtschatica Zone, middle Pliocene. $\times 1000$.

Figures 3, 4 Stephanopyxis dimorpha Schrader. Slide 3009, $31 \mu$ in diameter, Sample 302-2-5, 31$32 \mathrm{~cm}$, Actinocyclus oculatus Zone, lower Pleistocene. $\times 1000$.

Figures 5, 6 Stephanopyxis dimorpha Schrader. Slide 3015, 33 $\mu$ in diameter, Sample 302-2, CC, $31-32 \mathrm{~cm}$, Actinocyclus oculatus Zone, lower Pleistocene. $\times 1000$.

Figures 7, 8 Stephanopyxis horridus Koizumi. Slide 3171, 37 $\mu$ in diameter, Sample 301-11, CC, Denticula seminae var. fossilis Zone, upper Pliocene. $\times 1000$.

Figure 9 Thalassiosira antiqua (Grun.) Cl. Slide 3175, 35 $\mu$ in diameter, Sample 301-13-1, 50-51 $\mathrm{cm}$, Denticula seminae var. fossilis-Denticula kamtschatica Zone, middle Pliocene. $\times 1000$.

Figures 10, 11 Thalassiosira decipiens (Grun.) Joerg. Slide 3073, $21 \mu$ in diameter, Sample 302-10-1, $10-11 \mathrm{~cm}$, Denticula kamtschatica Zone, lower Pliocene. $\times 1000$.

Figure 12 Thalassiosira decipiens (Grun.) Joerg. Slide 3073, $19 \mu$ in diameter, Sample 302-10-1, $10-11 \mathrm{~cm}$, Denticula kamtschatica Zone, lower Pliocene. $\times 1000$.

Figures 13, 14 Thalassiosira decipiens (Grun.) Joerg. Slide 3073, 22 $\mu$ in diameter, Sample 302-10-1, $10-11 \mathrm{~cm}$, Denticula kamtschatica Zone, lower Pliocene. $\times 1000$.

Figures 15, 16 Thalassiosira convexa Muchina. Slide 3387, $29 \mu$ in diameter, Sample 299-30-5, 31-32 $\mathrm{cm}$, Denticula seminae var. fossilis-Denticula kamtschatica Zone, middle Pliocene. $\times 1000$.

Figures 17, 18 Thalassiosira convexa Muchina. Slide 3179, 30 $\mu$ in diameter, Sample 301-14-1, 68-69 $\mathrm{cm}$, Denticula seminae var. fossilis-Denticula kamtschatica Zone, middle Pliocene. $\times 1000$.

Figures 19, 20 Thalassiosira convexa Muchina. Slide 3181, 40 $\mu$ in diameter, Sample 301-14, CC, Denticula seminae var. fossilis-Denticula kamtschatica Zone, middle Pliocene. $\times 1000$.

Figure 21 Thalassiosira nativa Sheshuk. Slide 3095, 22 $\mu$ in diameter, Sample 302-15, CC, Denticula kamtschatica Zone, lower Pliocene. $\times 1000$.

Figure 22 Thalassiosira nativa Sheshuk. Slide 3101, 30 $\mu$ in diameter, Sample 302-16-1, 98-99 $\mathrm{cm}$, Denticula kamtschatica Zone, lower Pliocene. $\times 1000$.

Figure 23 Thalassiosira hyalina (Grun.) Grun. Slide 3351, $28 \mu$ in diameter, Sample 299-19, CC, Denticula seminae var. fossilis Zone, upper Pliocene. $\times 1000$.

Figure 24 Thalassiosira nordenskiöldi $\mathrm{Cl}$. Slide 3115, $21 \mu$ in diameter, Sample 301-2-3, 35-36 $\mathrm{cm}$, Rhizosolenia curvirostris Zone, middle Pleistocene. $\times 1000$.

Figures 25, 26 Thalassiosira kryophila (Grun.) Joerg. Slide 3177, 32 $\mu$ in diameter, Sample 301-13, CC, Denticula seminae var. fossilis-Denticula kamtschatica Zone, middle Pliocene. $\times 1000$. 
PLATE 4 (Continued)

Figure 27 Thalassiosira nidulus (Temp. and Brun) Jousé. Slide 3125, $22 \mu$ in diameter, Sample 301-3, CC, Actinocyclus oculatus Zone, lower Pleistocene. $\times 1000$.

Figure 28 Thalassiosira nidulus (Temp. and Brun) Jousé. Slide 3041, $28 \mu$ in diameter, Sample 302-5-4, 20-21 cm, Denticula seminae var. fossilis-Denticula kamtschatica Zone, middle Pliocene. $\times 1000$.

Figure 29 Porosira glacialis (Grun.) Joerg. Slide 3121, $49 \mu$ in diameter, Sample 301-2, CC, Rhizosolenia curvirostris Zone, middle Pleistocene. $\times 1000$. 
PLATE 4
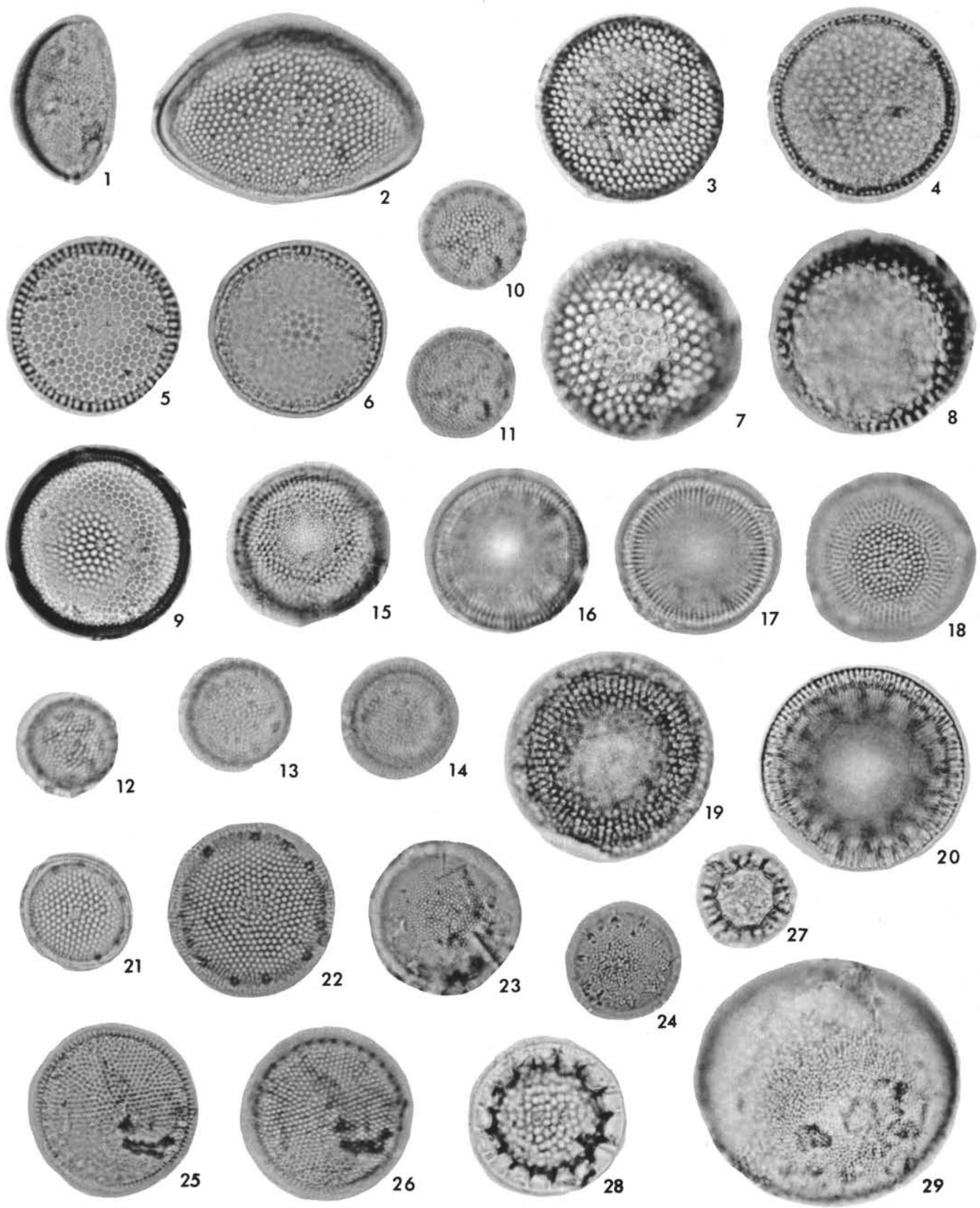


\section{PLATE 5}

Figures 1, 2 Porosira glacialis (Grun.) Joerg. Slide 3015, 37 $\mu$ in diameter, Sample 302-2, CC, Actinocyclus oculatus Zone, lower Pleistocene. $\times 1000$.

Figure 3 Thalassiosira oestrupi (Ostf.) Pr. Slide 3005, 29 $\mu$ in diameter, Sample 302-2-3, 23-24 $\mathrm{cm}$, Rhizosolenia curvirostris Zone, middle Pleistocene. $\times 1000$.

Figure 4 Thalassiosira oestrupi (Ostf.) Pr. Slide 3205, 22 $\mu$ in diameter, Sample 301-19-1, 72-73 $\mathrm{cm}$, Denticula kamtschatica Zone, lower Pleistocene. $\times 1000$.

Figure 5 Thalassiosira undulosa (Mann) Sheshuk. Slide 3085, $27 \mu$ in diameter, Sample 302-121, 60-61 cm, Denticula kamtschatica Zone, lower Pliocene. $\times 1000$.

Figure 6 Thalassiosira manifesta Sheshuk. Slide 3089, 32 $\mu$ in diameter, Sample 302-13-1, 13-14 $\mathrm{cm}$, Denticula kamtschatica Zone, lower Pliocene. $\times 1000$.

Figures 7,8 Thalassiosira gravida $\mathrm{Cl}$. forma fossilis Jousé. Slide $3135,33 \mu$ in diameter, Sample 301-4, CC, Actinocyclus oculatus Zone, lower Pleistocene. $\times 1000$.

Figures 9, 10 Thalassiosira gravida $\mathrm{Cl}$. forma fossilis Jousé. Slide 3197, $42 \mu$ in diameter, Sample 301-18-1, 68-69 cm, Denticula kamtschatica Zone, lower Pliocene. $\times 1000$.

Figures 11, 12 Thalassiosira gravida $\mathrm{Cl}$. forma fossilis Jousé. Slide $3151,27 \mu$ in diameter, Sample 301-6, CC, Actinocyclus oculatus Zone (?), lower Pleistocene (?). $\times 1000$.

Figure 13 Thalassiosira zabelinae Jousé. Slide 3003, 34 $\mu$ in diameter, Sample 302-2-1, 80-81 cm, Rhizosolenia curvirostris Zone, middle Pleistocene. $\times 1000$.

Figures 14, 15 Thalassiosira zabelinae Jousé. Slide 3189, 32 $\mu$ in diameter, Sample 301-16-1, 71-72 $\mathrm{cm}$, Denticula seminae var. fossilis-Denticula kamtschatica Zone, middle Pliocene. $\times 1000$.

Figures 16, 17 Thalassiosira zabelinae Jousé. Slide 3183, 48 $\mu$ in diameter, Sample 301-15-1, 13-14 $\mathrm{cm}$, Denticula seminae var. fossilis-Denticula kamtschatica Zone, middle Pliocene. $\times 1000$.

Figures 18, 19 Thalassiosira usatschevii Jousé. Slide 3065, 35 $\mu$ in diameter, Sample 302-8-5, 10-11 $\mathrm{cm}$, Denticula kamtschatica Zone, lower Pliocene.

Figures 20,21 Thalassiosira usatschevii Jousé. Slide 3193, 45 $\mu$ in diameter, Sample 301-17-1, 30-31 $\mathrm{cm}$, Denticula kamtschatica Zone, lower Pliocene. $\times 1000$.

Figure 22 Thalassiosira lineata Jousé. Slide 3115, $19 \mu$ in diameter, Sample 301-2-3, 35-36 cm, Rhizosolenia curvirostris Zone, middle Pleistocene. $\times 1000$.

Figure 23 Thalassiosira sp. 1. Slide 3041, 33 $\mu$ in diameter, Sample 302-5-4, 20-21 cm, Denticula seminae var. fossilis-Denticula kamtschatica Zone, middle Pliocene. $\times 1000$.

Figure 24 Thalassiosira sp. 1. Slide 3337, $51 \mu$ in diameter, Sample 299-18, CC, Denticula seminae var. fossilis Zone, upper Pliocene. $\times 1000$. 
PLATE 5
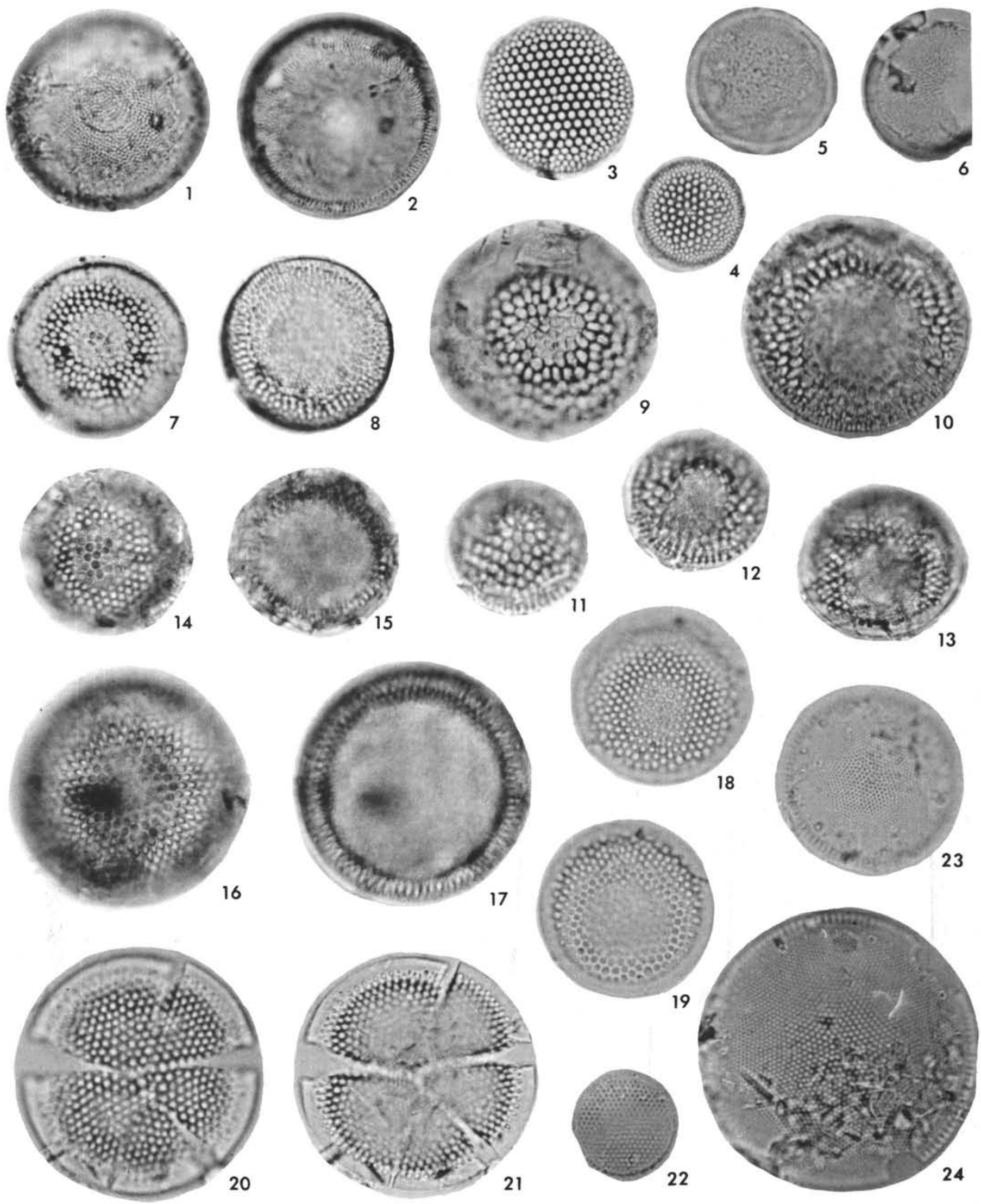